\title{
HEALTH AND CLIMATE INCENTIVES FOR THE DEPLOYMENT OF CLEANER ON-ROAD VEHICLE TECHNOLOGIES
}

\author{
Laura Minet $^{1}$, An Wang ${ }^{1}$, Marianne Hatzopoulou ${ }^{1 *}$ \\ ${ }^{1}$ Department of Civil and Mineral Engineering, University of Toronto, Toronto, Ontario, Canada \\ 35 St George Street, Toronto, ON M5S 1A4 \\ *Corresponding author \\ Telephone: 416-978-0864. Email: marianne.hatzopoulou@utoronto.ca
}

This supplementary information provides information on 1) the setup and validation of the CTM, 2) the distribution of exposures by region and by census characteristics, 3) the results of the assessment of the health outcomes. 


\section{Table of Contents}

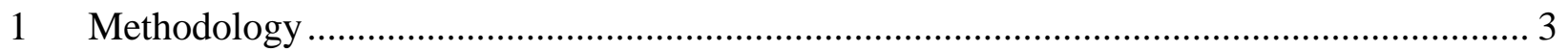

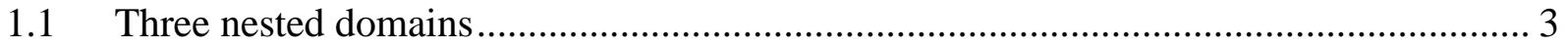

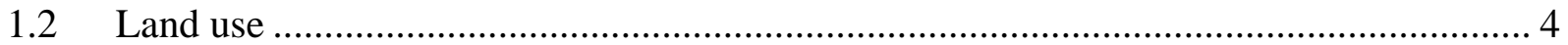

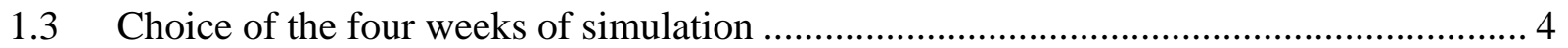

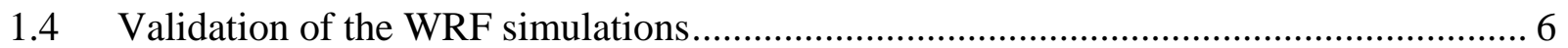

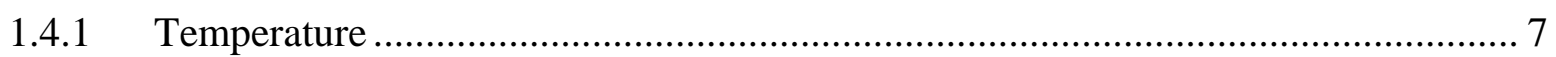

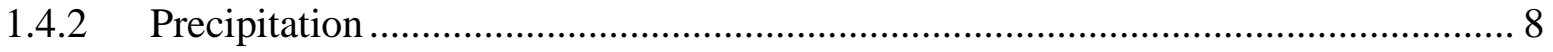

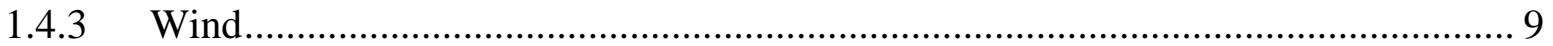

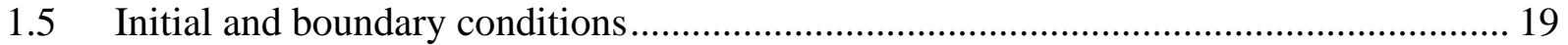

1.6 Discretization and speciation of the PM emissions..................................................... 22

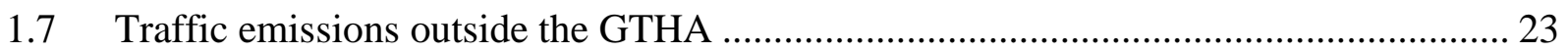

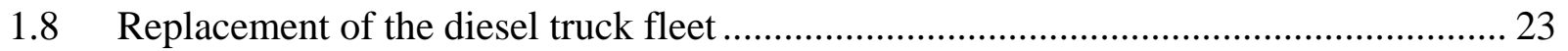

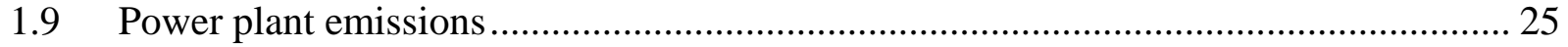

1.10 Spare capacity of natural gas power plants in Ontario …………………………..... 26

1.11 Energy consumption rate of battery electric buses (BEBs) ....................................... 27

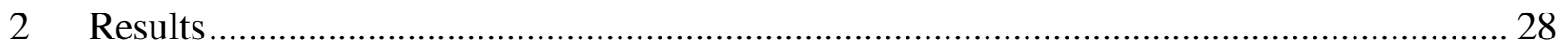

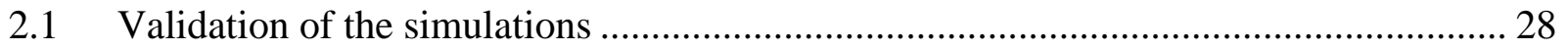

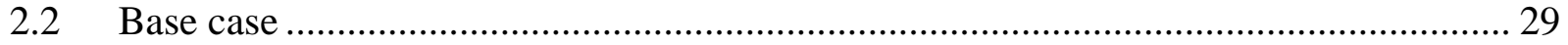

2.3 Changes in ambient concentrations under the different study cases and scenarios ........ 31

2.4 Changes in population exposure under the study cases and scenarios............................. 35

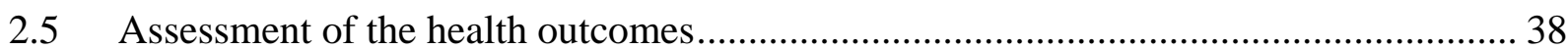

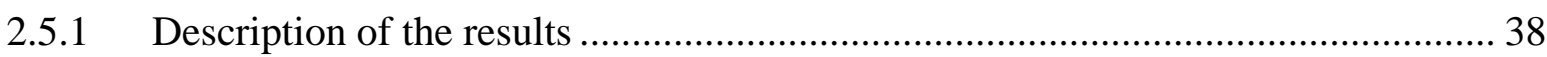

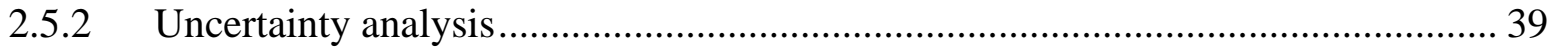

2.5.3 Comparison of the four weeks simulated........................................................... 39

2.6 Results obtained with the Air Quality Benefits Assessment Tool (AQBAT) of Health

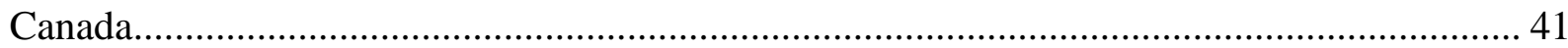

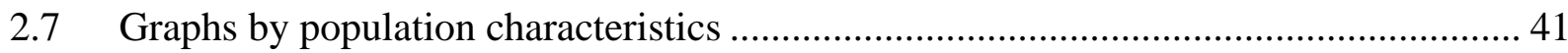

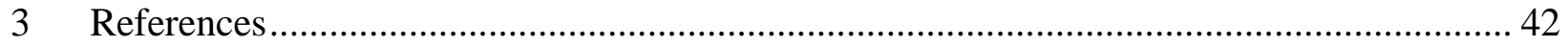




\section{METHODOLOGY}

\subsection{Three nested domains}

Figure S1 displays the three nested domains of the chemical transport model (CTM) simulation:

- D1 is the largest domain, and has a spatial resolution of $12 \mathrm{~km}^{2}$;

- D2 has a spatial resolution of $4 \mathrm{~km}^{2}$;

- D3 is the domain of interest, slightly larger than the GTHA, and has a spatial resolution of $1 \mathrm{~km}^{2}$.

The three domains extend to the U.S. and encompass emissions from power plants located in New York State (NYS).

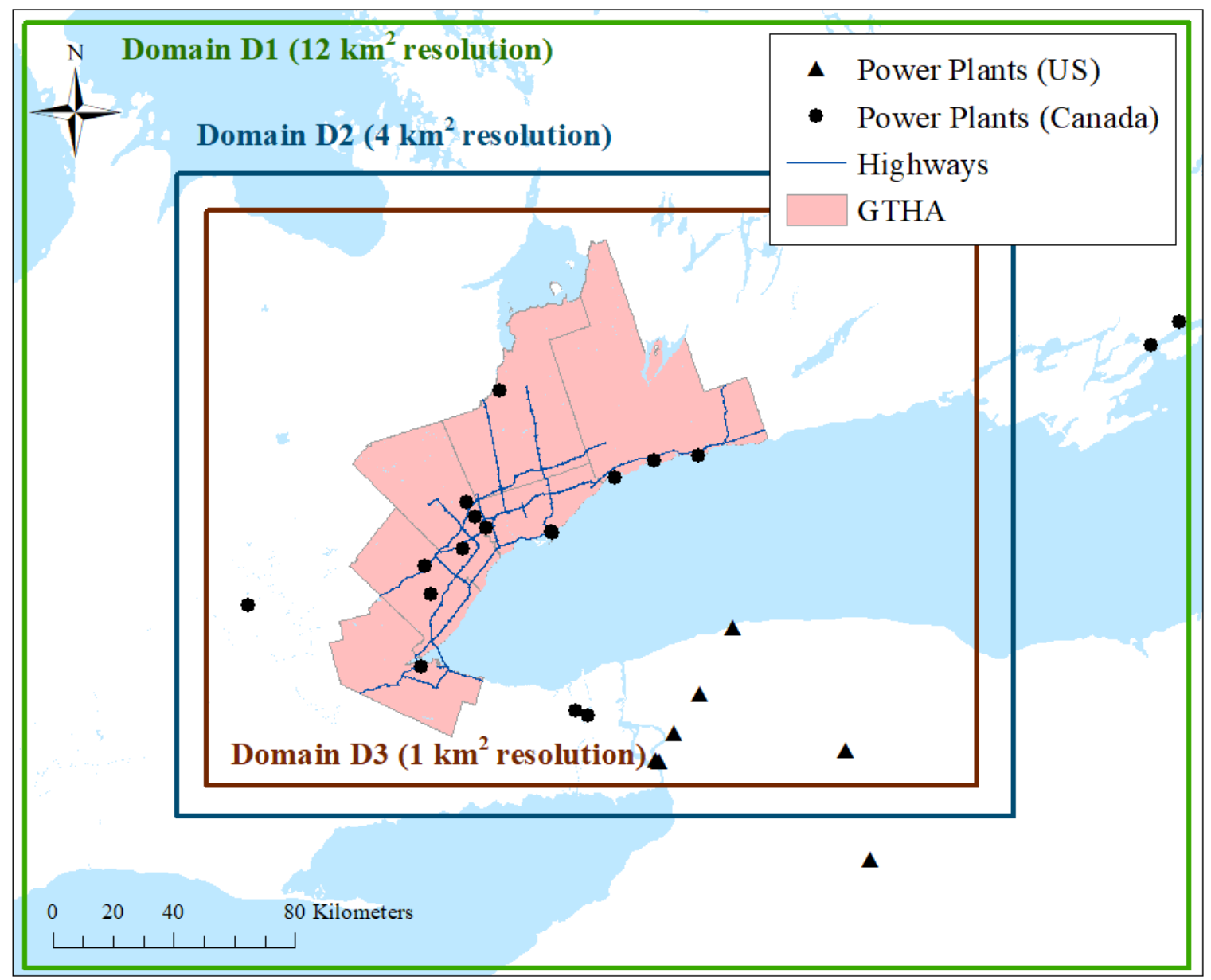

Figure S1 Three nested domains of the chemical transport model simulation 


\subsection{Land use}

Land use data was mainly provided by the Global Land Cover 2000 (GLC2000) ${ }^{1}$ dataset, which has a spatial resolution of $1 \mathrm{~km}^{2}$ at the equator. For each grid cell of the domains, the percentage of land covered by each of the 23 different categories of GLC20002 is determined.

To account for recent land use changes (e.g., extension of the urban area), we combined the GLC2000 dataset with DMTI data from 2013. The DMTI dataset is divided into seven categories: Commercial, Governmental and Institutional, Residential, Parks and Recreational, Open Area, Resource and Industrial, and Waterbody. In the grid cells of our domains covered by the DMTI dataset, we converted the DMTI land use into the GLC2000 classification as follows:

- Commercial, Governmental and Institutional, Residential, Resource and Industrial, and Open Area were attributed to "Artificial Area"

- Waterbody was attributed to "Water Bodies"

- Parks and recreational was attributed to "Shrub area, closed-open, deciduous"

\subsection{Choice of the four weeks of simulation}

We chose four weeks of simulation to be representative of average temperature, precipitation and wind speed for each season of the year 2016. We used data collected at Toronto City Center station.

We first focused on temperature, and compared average seasonal temperatures with distributions of hourly temperatures over each week of the year (Figure S2).
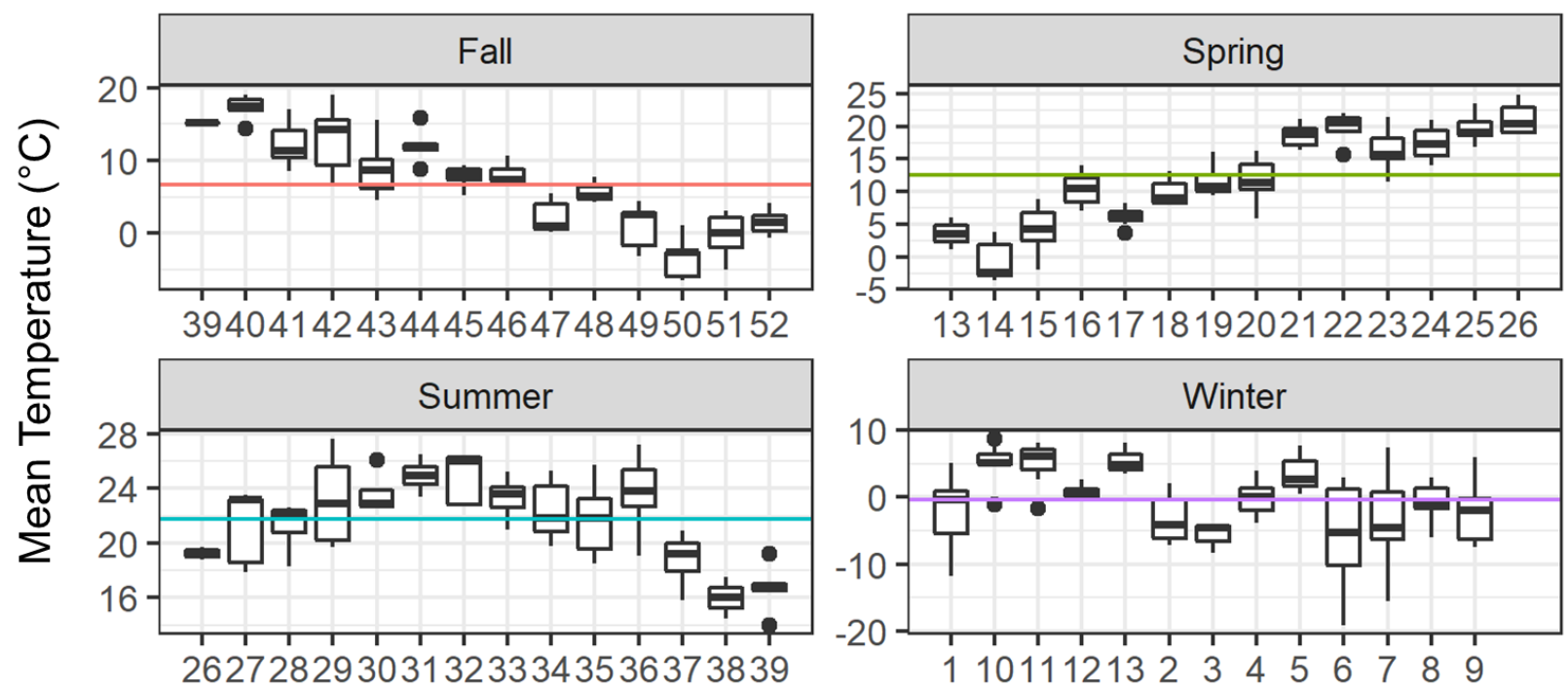

Week of the year 2016

Figure S2 Distribution of hourly temperatures recorded at Toronto City Center meteorological station during each week of 2016, and comparison with the average seasonal temperature (horizontal line) 
We identified the weeks of each season with distributions of temperatures intersecting the average seasonal average:

- Fall: weeks 43, 45, 48

- $\quad$ Spring: weeks 16, 18, 19, 20, 23

- $\quad$ Summer: weeks 27, 28, 29, 33, 34, 35, 36

- Winter: weeks 1, 2, 4, 6, 7, 8, 9, 12

Then, we investigated the distribution of total daily precipitations of each of the weeks preselected and compared them with the average daily precipitations for each season (Figure S3).
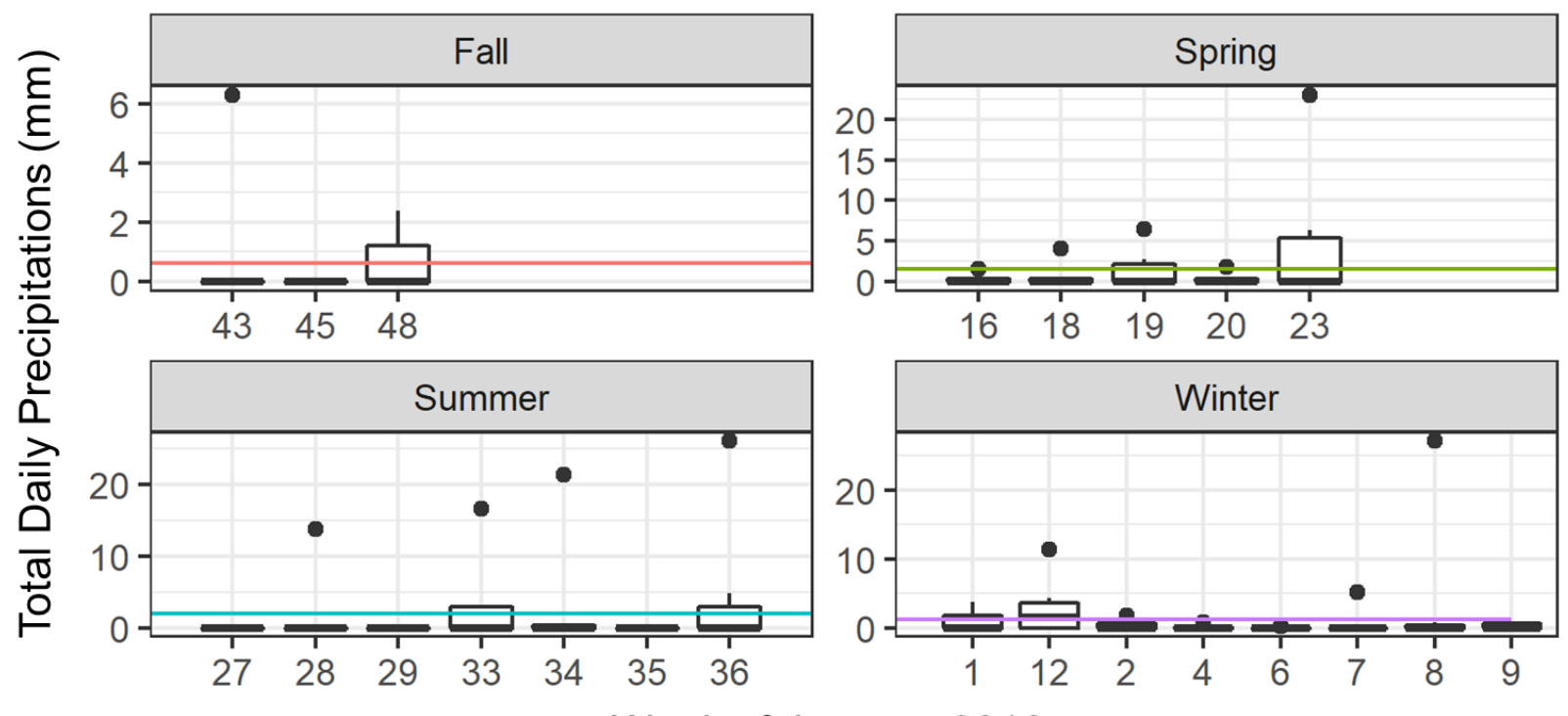

Week of the year 2016

Figure S3 Distribution of total daily precipitations recorded at Toronto City Center meteorological station during the weeks of 2016 selected based on their agreement with average seasonal temperatures, and comparison with the average seasonal daily total precipitations (horizontal line)

Based on this second comparison, we selected the following weeks:

- Fall: week 48

- Spring: week 19

- $\quad$ Summer: weeks 33 and 36

- Winter: week 12

Finally, to confirm our choices, and choose between the two weeks of Summer, we compared the distributions of maximum hourly wind speeds recorded during each week with the average seasonal maximum wind speed (Figure S4). 

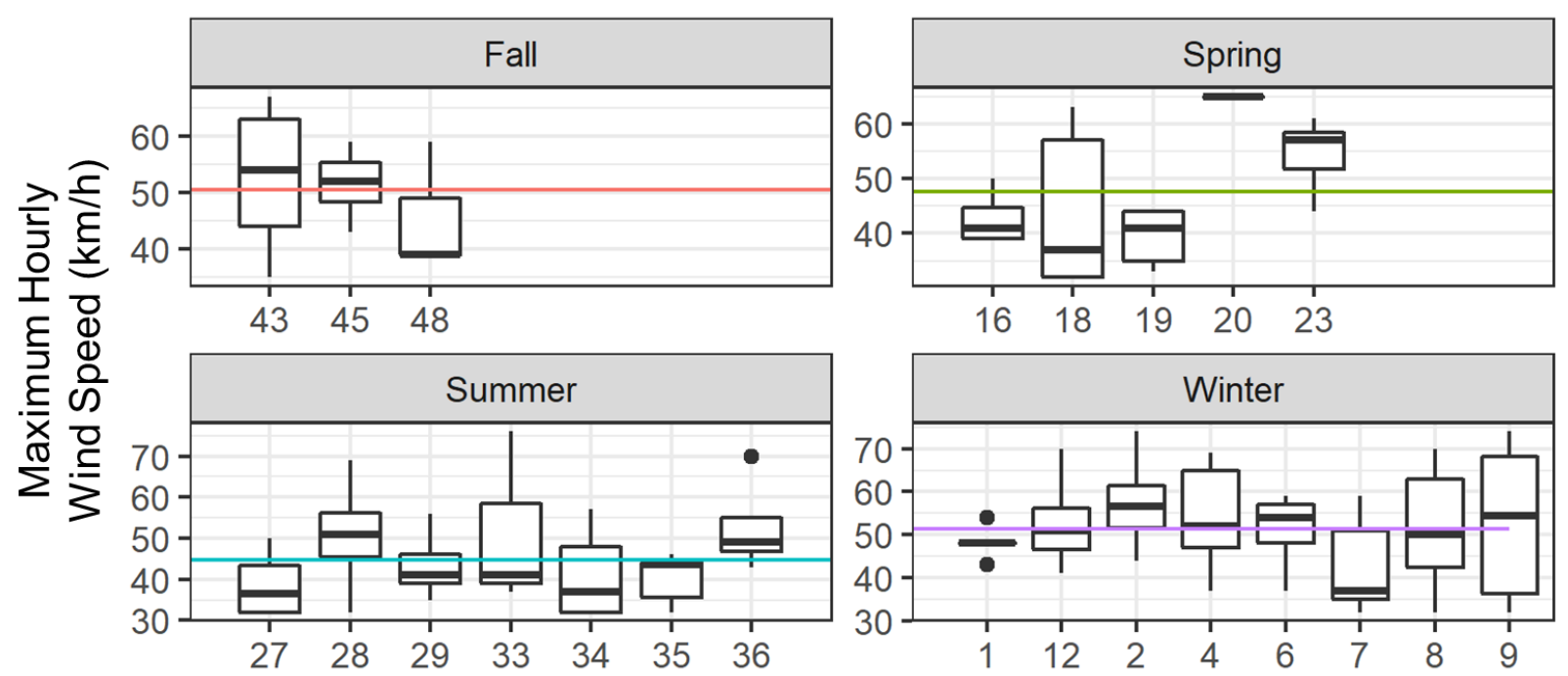

Week of the year 2016

Figure S4 Distribution of the maximum hourly wind speeds recorded at Toronto City Center station meteorological station during the weeks of 2016 selected based on their agreement with the average seasonal temperatures, and comparison with the average seasonal maximum wind speed (horizontal line)

Based on this final comparison, we chose the week 33 to represent average Summer meteorological conditions. Our final choice of weeks for 2016 is therefore:

- Winter: week 12 - March $20^{\text {th }}$ to March $26^{\text {th }}$

- $\quad$ Spring: week 19 - May $8^{\text {th }}$ to May $14^{\text {th }}$

- $\quad$ Summer: week 33 - August $14^{\text {th }}$ to August $20^{\text {th }}$

- $\quad$ Fall: week 48 - November $27^{\text {th }}$ to December $3^{\text {rd }}$

\subsection{Validation of the WRF simulations}

For the four weeks considered, we validated the WRF simulations against measurements of temperature, rain fall, and wind speed and direction at 21 meteorological stations located within or close to the GTHA (Figure S5). ${ }^{2}$ 


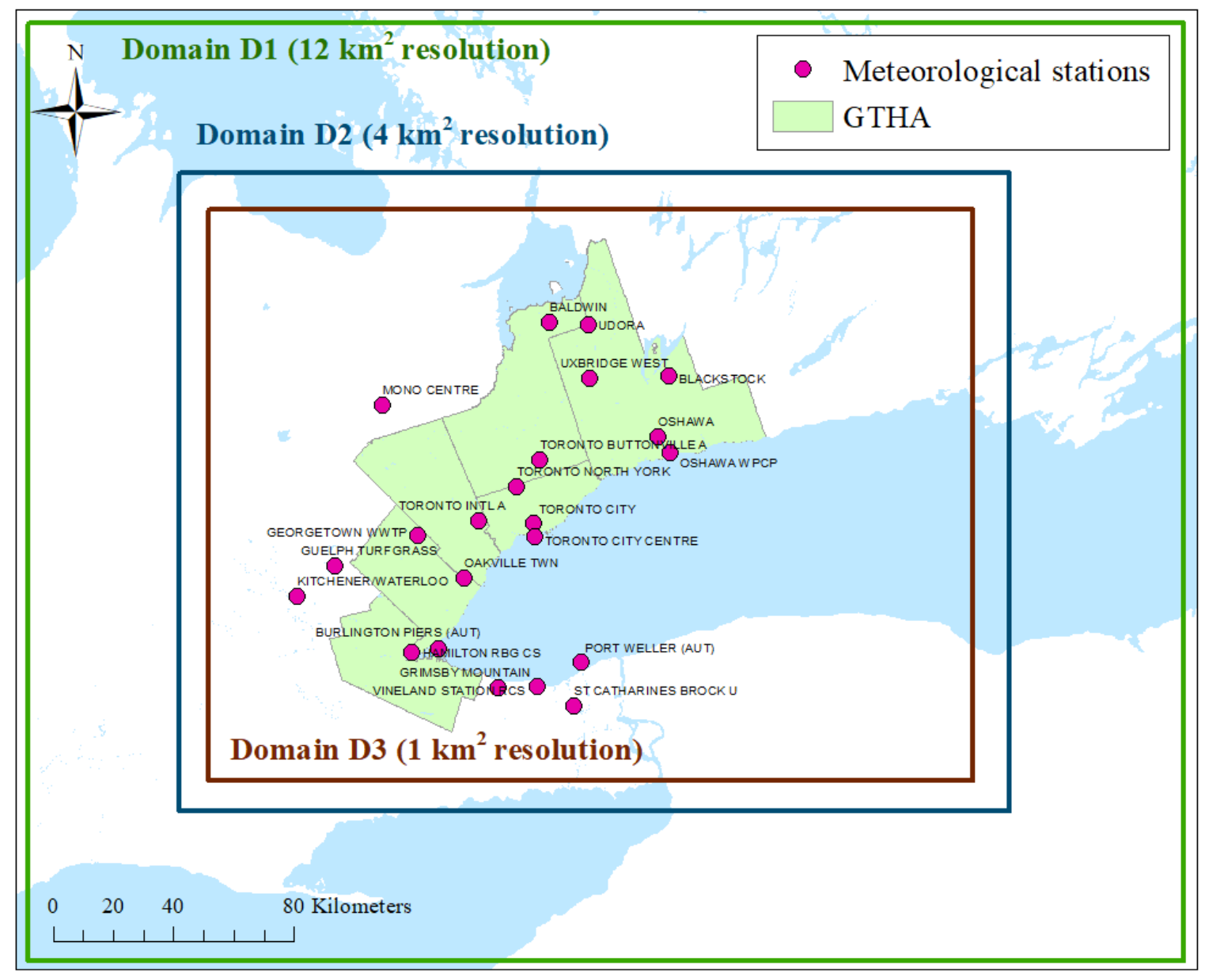

Figure S5 Meteorological stations used to validated the WRF simulations

\subsubsection{Temperature}

For each week simulated, Table S1 provides a comparison of the average daily measured and WRF-simulated temperatures at 21 meteorological stations, as well as the Pearson correlation coefficient between the temperatures for each one of these stations.

On average, the temperatures measured and simulated are similar, and the Pearson correlation coefficients higher than 0.8 . The simulated temperatures tend to vary less than the measured temperatures. Indeed, in Winter (March), the temperatures recorded vary between -2.1 and $1.8^{\circ} \mathrm{C}$, while the temperatures simulated vary between -2.1 and $0.5^{\circ} \mathrm{C}$. In Spring (May), measured (simulated) temperatures vary between 9.2 and $12.4^{\circ} \mathrm{C}\left(8.8\right.$ and $\left.10.6{ }^{\circ} \mathrm{C}\right)$. For Summer (August), the temperatures observed vary between 21 and $24.3^{\circ} \mathrm{C}$, and the simulated temperatures are comprised between 20.5 and $22.3^{\circ} \mathrm{C}$. Finally, in Fall (November/December), measured (simulated) temperatures range between 3.8 and $7.8^{\circ} \mathrm{C}\left(2.6\right.$ and $\left.6{ }^{\circ} \mathrm{C}\right)$. 
We observe slightly lower Pearson coefficients for the stations Toronto City centre and Toronto City in Winter (March), and for Georgetown WWTP in Summer (August).

Table S1 Comparison of the averaged daily measured and WRF-simulated temperatures at 21 meteorological stations of the GTHA, and Pearson correlation coefficient between the daily temperatures - Average measured / Average simulated (Pearson correlation coefficient)

\begin{tabular}{|c|c|c|c|c|}
\hline Station & Winter (March) & Spring (May) & $\begin{array}{l}\text { Summer } \\
\text { (August) }\end{array}$ & Fall (November) \\
\hline KITCHENER/WATERLOO & $-0.41 /-0.76(0.83)$ & $10.1 / 10.1(0.99)$ & $21.6 / 20.7(0.91)$ & 4 / $3.4(0.99)$ \\
\hline $\begin{array}{c}\text { TORONTO NORTH } \\
\text { YORK } \\
\end{array}$ & $-0.04 /-0.71(0.92)$ & $11.7 / 10.5(0.99)$ & $23.7 / 21.8(0.73)$ & $4.9 / 3.9(0.88)$ \\
\hline OAKVILLE TWN & $0.51 /-0.25(0.83)$ & $12.1 / 10.6(0.97)$ & $24 / 21.9(0.81)$ & $6.1 / 4.4(0.85)$ \\
\hline OSHAWA WPCP & $-0.34 /-0.71(0.93)$ & $11.3 / 8.8(0.98)$ & $22.6 / 21.3(0.88)$ & $5.6 / 4.1(0.91)$ \\
\hline GRIMSBY MOUNTAIN & $1.3 / 0(0.8)$ & $12 / 10.3(0.99)$ & $24.1 / 22.1(0.97)$ & $6.4 / 5.7(0.97)$ \\
\hline GEORGETOWN WWTP & $0.12 /-0.67(0.84)$ & $9.8 / 10.3(0.75)$ & $21.9 / 21.4(0.41)$ & $5 / 3.6(0.94)$ \\
\hline BALDWIN & $-1.22 /-2.15(0.87)$ & $10.8 / 9.5(0.95)$ & $21 / 20.4(0.92)$ & $4.7 / 3.5(0.97)$ \\
\hline UDORA & $-1.41 /-1.88(0.8)$ & $10.8 / 9.9(1)$ & $21.5 / 20.4(0.96)$ & 4.2 / $3.4(0.99)$ \\
\hline BLACKSTOCK & $-1.77 /-1.81(0.88)$ & $10 / 10(0.99)$ & $0 / 19.9(0)$ & $0 / 3.8(0)$ \\
\hline TORONTO CITY & $1.15 /-0.35(0.67)$ & $12.4 / 10.1(0.93)$ & $24.3 / 22.3(0.92)$ & $6.8 / 4.5(0.96)$ \\
\hline TORONTO CITY CENTRE & $0.75 /-0.05(0.7)$ & 11.7 / $9.7(0.99)$ & $23.3 / 22.3(0.89)$ & $5.7 / 4.8(1)$ \\
\hline TORONTO INTL A & $0.14 /-0.18(0.83)$ & $11.1 / 10.7(0.95)$ & $23.8 / 21.8(0.93)$ & $6 / 4.3(0.97)$ \\
\hline $\begin{array}{c}\text { TORONTO } \\
\text { BUTTONVILLE A }\end{array}$ & $-0.68 /-0.86(0.75)$ & $11 / 10.2(0.97)$ & $22.9 / 21.5(0.92)$ & $5 / 3.8(0.98)$ \\
\hline PORT WELLER (AUT) & $1.77 / 0.24(0.91)$ & $10.6 / 9.3(0.95)$ & $24.4 / 21.6(0.87)$ & 7.4 / $5.9(0.96)$ \\
\hline OSHAWA & $-1.51 /-0.6(0.81)$ & $10.7 / 9.6(0.96)$ & $21.2 / 21.2(0.92)$ & $3.9 / 3.9(0.85)$ \\
\hline $\begin{array}{l}\text { BURLINGTON PIERS } \\
\text { (AUT) }\end{array}$ & $1.17 / 0.52(0.96)$ & $11 / 10(0.98)$ & $24.1 / 22.3(0.96)$ & $6.5 / 5(0.94)$ \\
\hline $\begin{array}{c}\text { VINELAND STATION } \\
\text { RCS } \\
\end{array}$ & $1.78 / 0(0.92)$ & $10.6 / 9.8(0.98)$ & $24.4 / 21.7(0.85)$ & $6.9 / 6(0.96)$ \\
\hline UXBRIDGE WEST & $-2.09 /-1.81(0.87)$ & $9.2 / 9.8(0.93)$ & $20.4 / 20.5(0.84)$ & $3.9 / 3.2(0.99)$ \\
\hline HAMILTON RBG CS & $0.72 / 0.43(0.86)$ & $10.8 / 10.5(0.95)$ & $22.7 / 22.6(0.94)$ & $5.3 / 4.8(0.96)$ \\
\hline GUELPH TURFGRASS & $-1.2 /-1.09(0.79)$ & $9.6 / 9.8(1)$ & $21.6 / 20.9(0.78)$ & $3.9 / 3.2(0.97)$ \\
\hline MONO CENTRE & $-1.46 /-1.92(0.99)$ & $9.2 / 9.4(0.95)$ & $20.9 / 20.3(0.96)$ & $3.6 / 2.6(0.98)$ \\
\hline
\end{tabular}

\subsubsection{Precipitation}

Some stations did not provide a record of precipitations in 2016. The comparison between measured and simulated precipitations shows more discrepancies (Table S2). The absolute values of Pearson correlation coefficients between averaged simulated and measured weekly precipitations range between 0 and 0.9 . Depending on the season, the results for a same station vary considerably. For instance, the correlation coefficient between measured and simulated daily precipitations at the Kitchener/Waterloo station ranges between 0.19 in Summer (August) and 0.94 in Winter (March). 
Table S2 Comparison of the averaged daily measured and WRF-simulated precipitations at 21 meteorological stations of the GTHA, and Pearson correlation coefficient between the daily precipitations Average measured / Average simulated (Pearson correlation coefficient)

\begin{tabular}{|c|c|c|c|c|}
\hline Station & Winter (March) & Spring (May) & $\begin{array}{l}\text { Summer } \\
\text { (August) }\end{array}$ & Fall (November) \\
\hline KITCHENER/WATERLOO & $4.9 / 7.58(0.94)$ & $5.4 / 2.19(0.73)$ & $5.3 / 1.71(-0.19)$ & $1.6 / 1.7(0.94)$ \\
\hline $\begin{array}{c}\text { TORONTO NORTH } \\
\text { YORK }\end{array}$ & $0.4 / 3.27(0.62)$ & $3.8 / 1.33(-0.12)$ & $1.9 / 1.95(0.03)$ & $1.8 / 2.5(0.84)$ \\
\hline OAKVILLE TWN & $1.3 / 3.97(0.12)$ & $3.1 / 2.75(-0.24)$ & $5.2 / 1.53(-0.43)$ & $1.7 / 2.5(0.61)$ \\
\hline OSHAWA WPCP & $0.8 / 3.06(0.74)$ & $1 / 0.5(0.51)$ & $6.2 / 1.7(0.25)$ & $2.5 / 2.6(0.49)$ \\
\hline GRIMSBY MOUNTAIN & $5.7 / 3.14(0.25)$ & $1.3 / 4.51(-0.11)$ & $2 / 0.47(0.31)$ & $2.2 / 1.5(0.83)$ \\
\hline GEORGETOWN WWTP & $9.9 / 5.35(0.99)$ & $0 / 1.33(0)$ & $3.4 / 3.89(-0.53)$ & $2.9 / 3(0.43)$ \\
\hline BALDWIN & $1.2 / 6.96(-0.23)$ & $1.5 / 0.94(0.33)$ & $8.8 / 7.39(0.63)$ & $1.9 / 2.4(0.35)$ \\
\hline UDORA & $1.6 / 5.42(-0.26)$ & $3.3 / 1.05(0.01)$ & $5.5 / 6.56(0.63)$ & $2.1 / 2.8(0.43)$ \\
\hline BLACKSTOCK & $2.9 / 3.77(0.18)$ & $1.4 / 4.42(0.45)$ & $0 / 2.99(0)$ & $0 / 2.9(0)$ \\
\hline TORONTO CITY & $3 / 2.86(0.97)$ & $2 / 2.14(0.61)$ & $3.3 / 1.26(0.99)$ & $1.3 / 2.3(0.98)$ \\
\hline TORONTO CITY CENTRE & $2.9 / 2.64(0.54)$ & $1.6 / 1.73(0.71)$ & $3.2 / 0.64(0.97)$ & $0.8 / 2.2(0.98)$ \\
\hline TORONTO INTL A & $2.6 / 4.05(0.95)$ & $3.2 / 2.91(0)$ & $2.1 / 0.52(0.96)$ & $1.6 / 2.4(0.96)$ \\
\hline $\begin{array}{c}\text { TORONTO } \\
\text { BUTTONVILLE A }\end{array}$ & $2.7 / 3.15(0.82)$ & $3.2 / 1.93(0.7)$ & $2.4 / 1.94(0.99)$ & $2.2 / 2.5(0.97)$ \\
\hline PORT WELLER (AUT) & $3.4 / 2.67(0.02)$ & $1.2 / 1.39(0.68)$ & $1.8 / 0.08(0.52)$ & $1.3 / 0.9(0.71)$ \\
\hline OSHAWA & $1.6 / 3.39(0.85)$ & $1.9 / 1.45(0.99)$ & $5.2 / 1.25(1)$ & $0.7 / 2.4(0.99)$ \\
\hline $\begin{array}{c}\text { VINELAND STATION } \\
\text { RCS }\end{array}$ & $5.7 / 2.67(0.09)$ & $1.1 / 6.21(0.9)$ & $2.1 / 2.83(-0.01)$ & $0 / 3.3(0)$ \\
\hline UXBRIDGE WEST & $4.1 / 3.35(-0.15)$ & $3.1 / 2.4(-0.04)$ & $0.1 / 4.44(-0.25)$ & $1.5 / 0.8(0.81)$ \\
\hline HAMILTON RBG CS & $6.9 / 4.37(0.87)$ & $3.9 / 5.96(-0.19)$ & $5.9 / 2.15(0)$ & $1.8 / 2.8(0.7)$ \\
\hline MONO CENTRE & 13.7 / $8.93(0.97)$ & $3 / 0.42(0.56)$ & $7.3 / 0.56(0.98)$ & $1.7 / 3.4(0.94)$ \\
\hline
\end{tabular}

\subsubsection{Wind}

We developed wind roses for 7 stations based on the measurements and simulations from the WRF model for the four weeks (Tables S3 to S6).

In general, wind directions are well captured. The most important differences can be observed in the Toronto City Centre, which is located downtown Toronto and surrounded by tall buildings that influence the measured wind patterns which are not well captured by the simulation. 
Table S3 Wind roses based on hourly measurements and WRF simulations at 7 weather stations located within the GTHA for the week of March $20^{\text {th }}$ to $27^{\text {th }}, 2016(\mathrm{~km} / \mathrm{h})$

Meteorological Station

\section{Burlington Piers}

$\square[0.0 ; 2.0)$
$\square[2.0 \div 4.0)$
$\square[4.0 ; 6.0)$
$\square[6.0 ; 8.0)$
$\square[8.0 ; 10.0)$
$\square[10.0 ; 12.0)$
$\square[12.0 ;$ inf)

Guelph Turfgrass

$\square[0.0 ; 20)$
$\square[2.0 ; 4.0)$
$\square[4.0 ; 6.0)$
$\square[6.0 ; 8.0)$
$\square[8.0 ;$ inf $)$
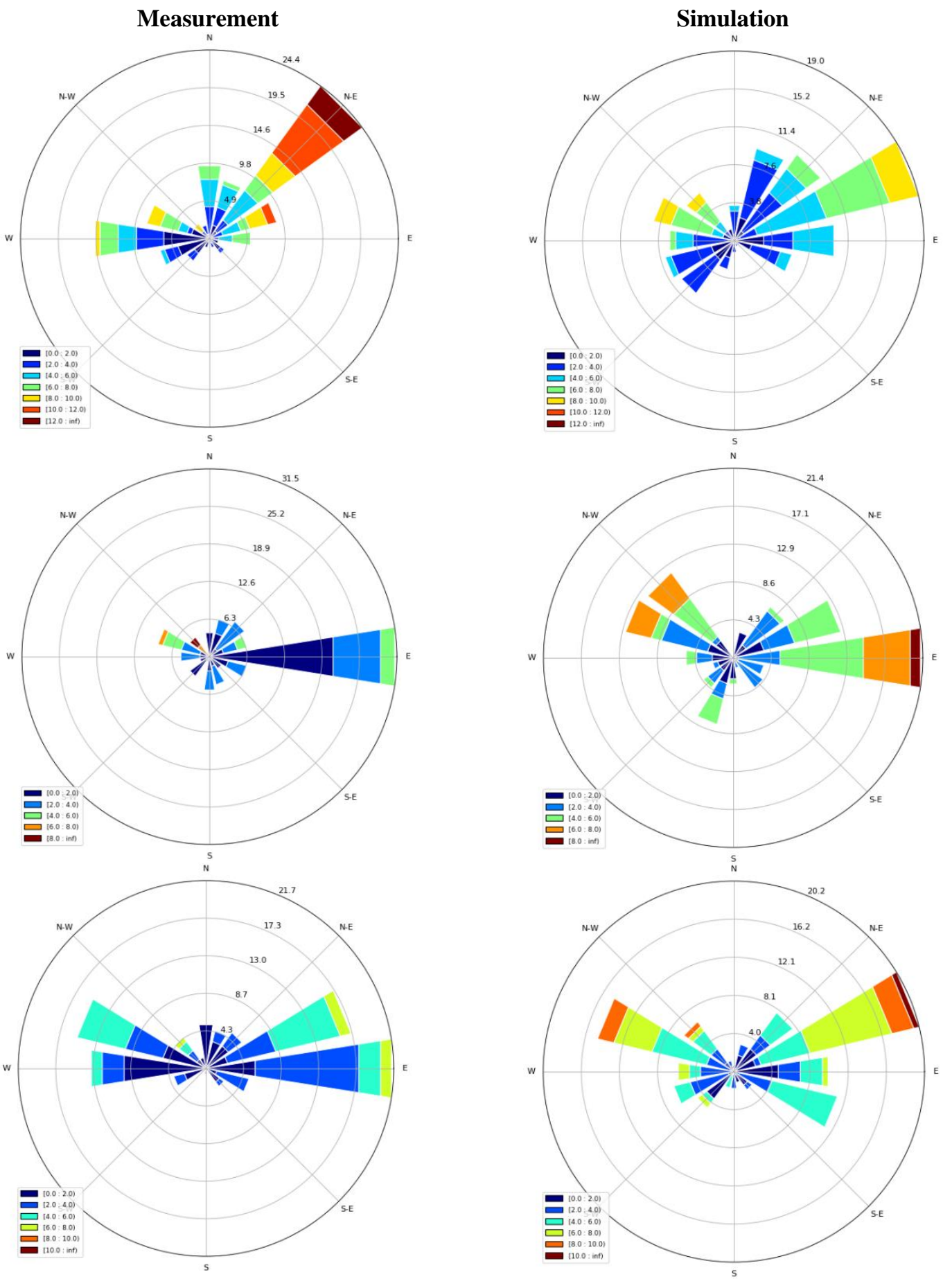
Kitchener Waterloo

$\square[0.0: 2.0)$
$[2.0 ; 4.0)$
$\square[4.0: 6.0)$
$\square[6.0 ; 8.0)$
$\square[8.0 ; 10.0)$
$\square[10.0 ;$ inf)

Mono centre

$[0.0 ; 2.0)$
$\square[2.0 ; 4.0)$
$\square[4.0 ; 6.0)$
$\square[6.0 ; 8.0)$
$\square[8.0 ;$ inf $)$

Toronto City Centre

$\square[0.0: 2.0)$
$\square[2.0 ; 4.0)$
$\square[4.0 ; 6.0)$
$\square[6.0 ; 8.0)$
$\square[8.0 ; 10.0]$
$\square[10.0 ; 12.0]$
$\square[12.0 ; 14.0]$
$\square[14.0 ; 16.0]$
$\square[16.0 ;$ inf)
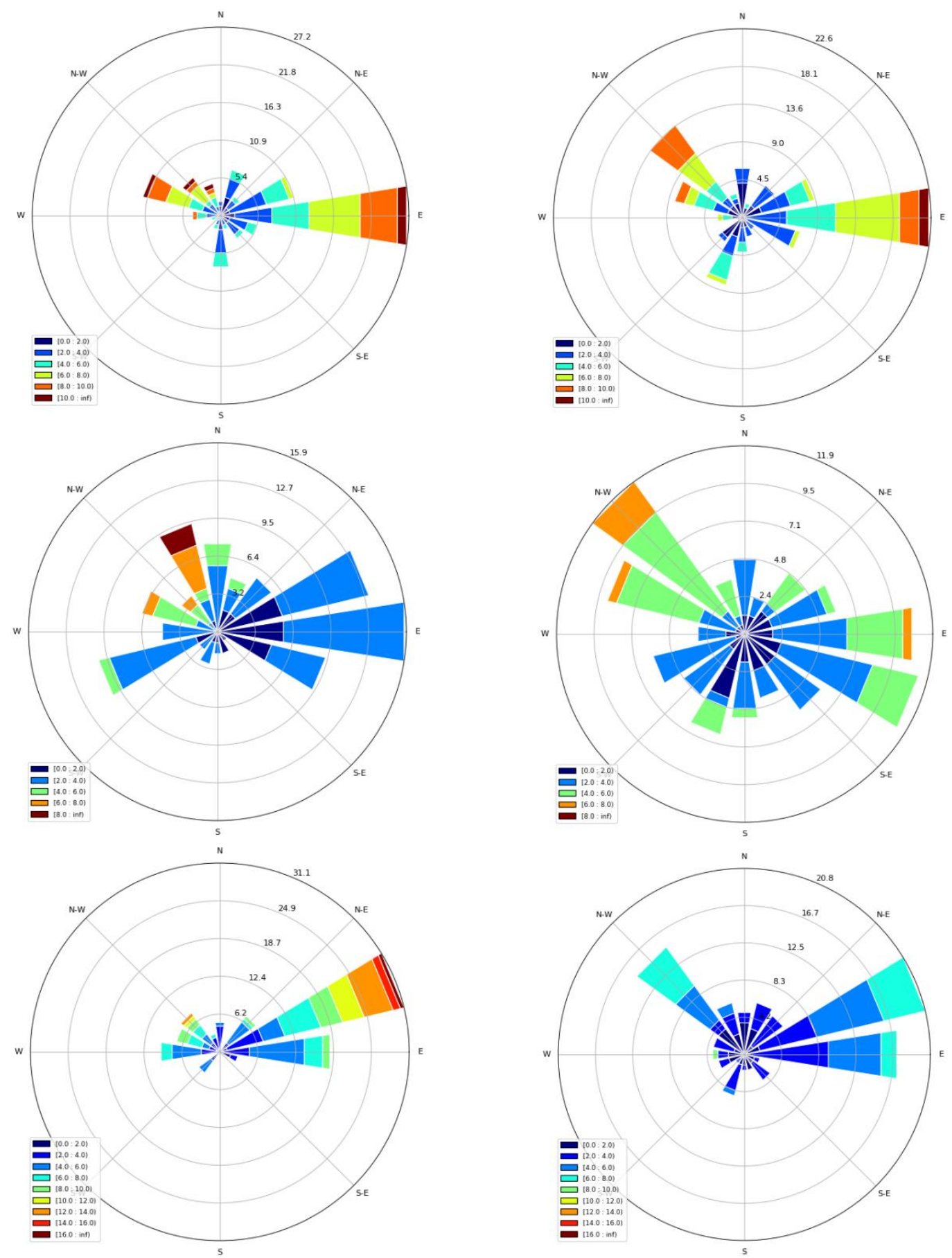

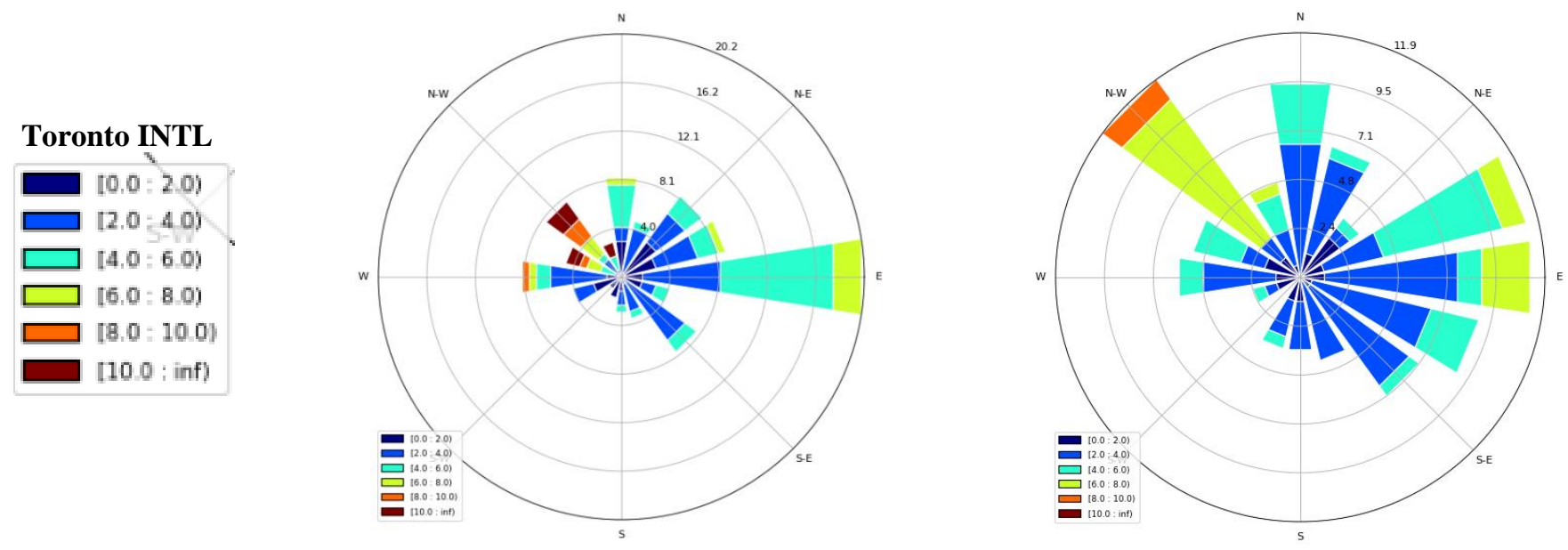

Table S4 Wind roses based on hourly measurements and WRF simulations at 7 weather stations located within the GTHA for the week of May $8^{\text {th }}$ to $14^{\text {th }}, 2016(\mathrm{~km} / \mathrm{h})$

Meteorological Station

Burlington Piers

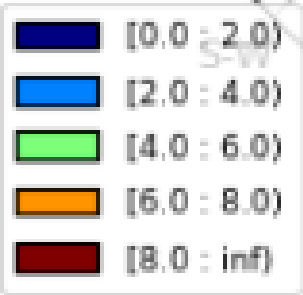

Guelph Turfgrass

$\square[0.0 ; 2.0)$
$\square[2.0 \div 4.0)$
$\square[4.0 \div 6.0)$
$\square[6.0 ; 8.0)$
$\square[8.0 ;$ inf $]$

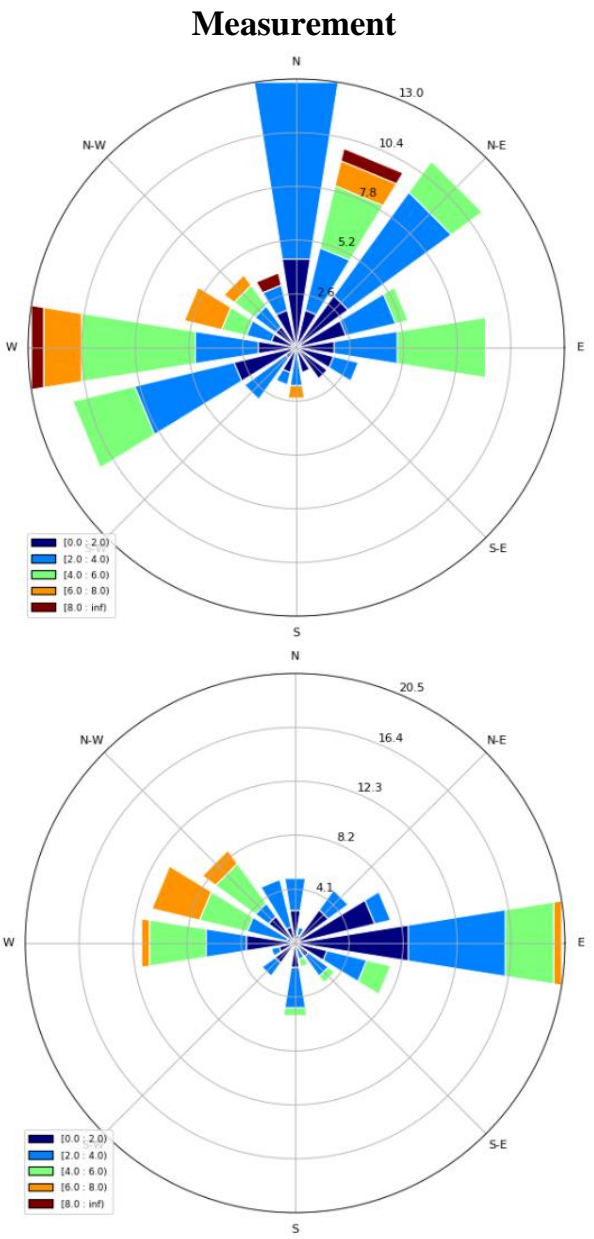

Simulation
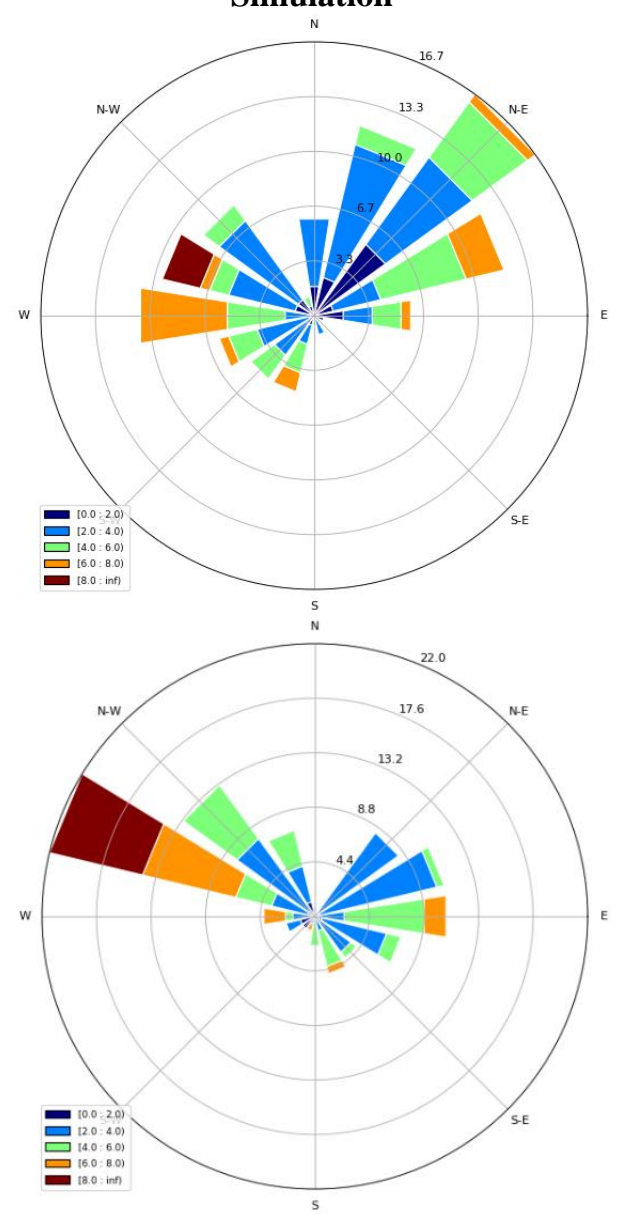

S12 


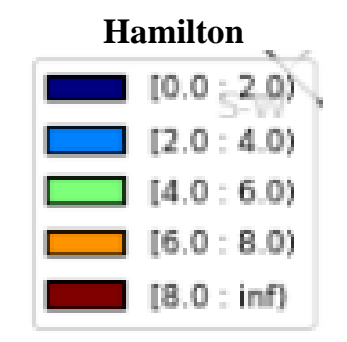

Kitchener Waterloo

\begin{tabular}{l}
$\square[0.0 ; 2.0)$ \\
$\square[2.0 ; 4.0)$ \\
$\square[4.0 ; 6.0)$ \\
$\square[6.0 ; 8.0)$ \\
$\square[8.0 ; 10.0)$ \\
$\square[10.0 ;$ inf) \\
\hline
\end{tabular}

Mono centre

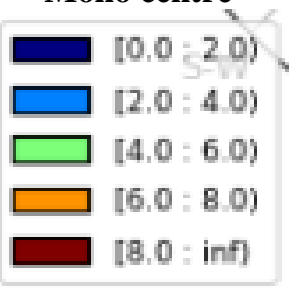
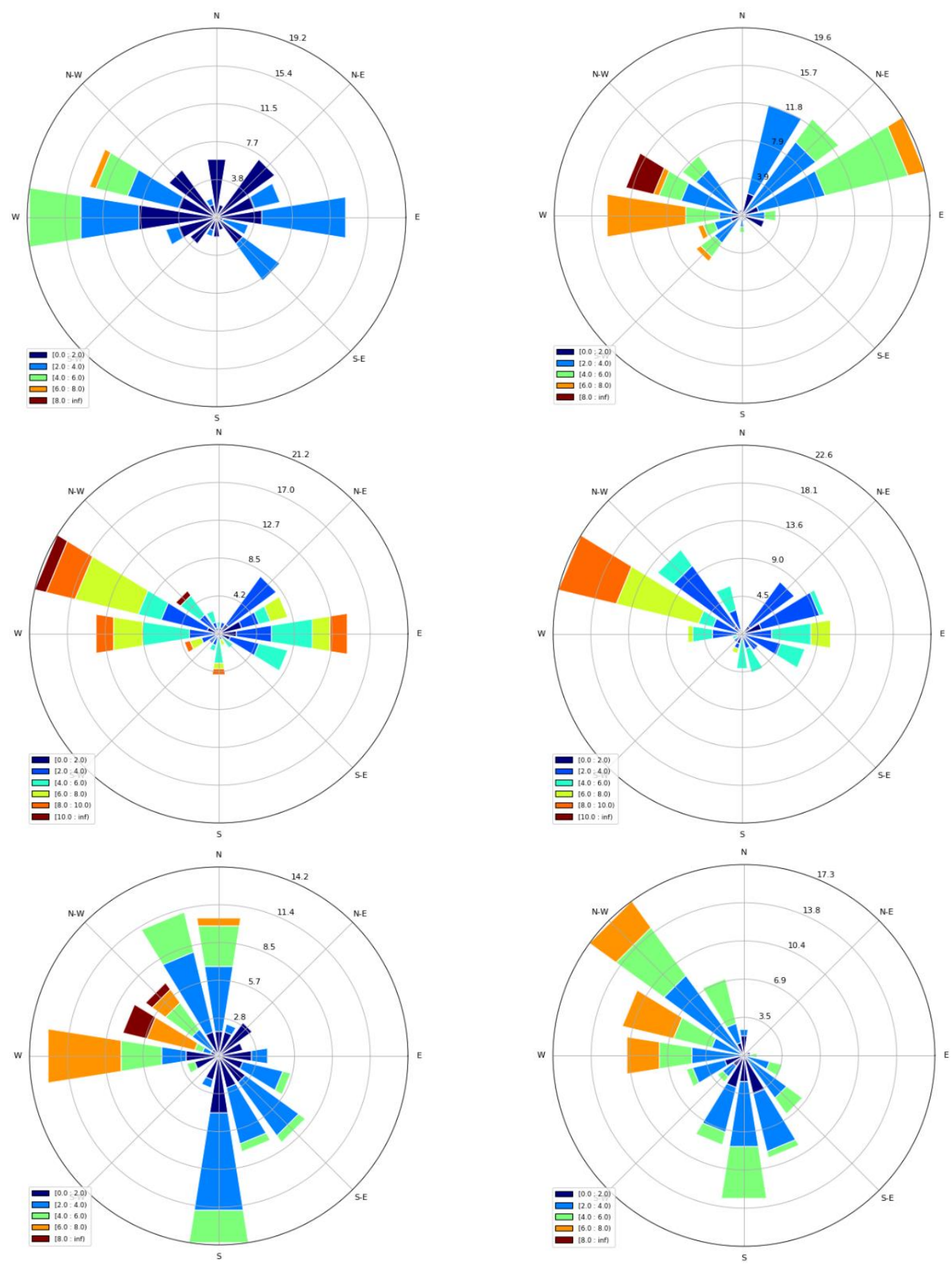

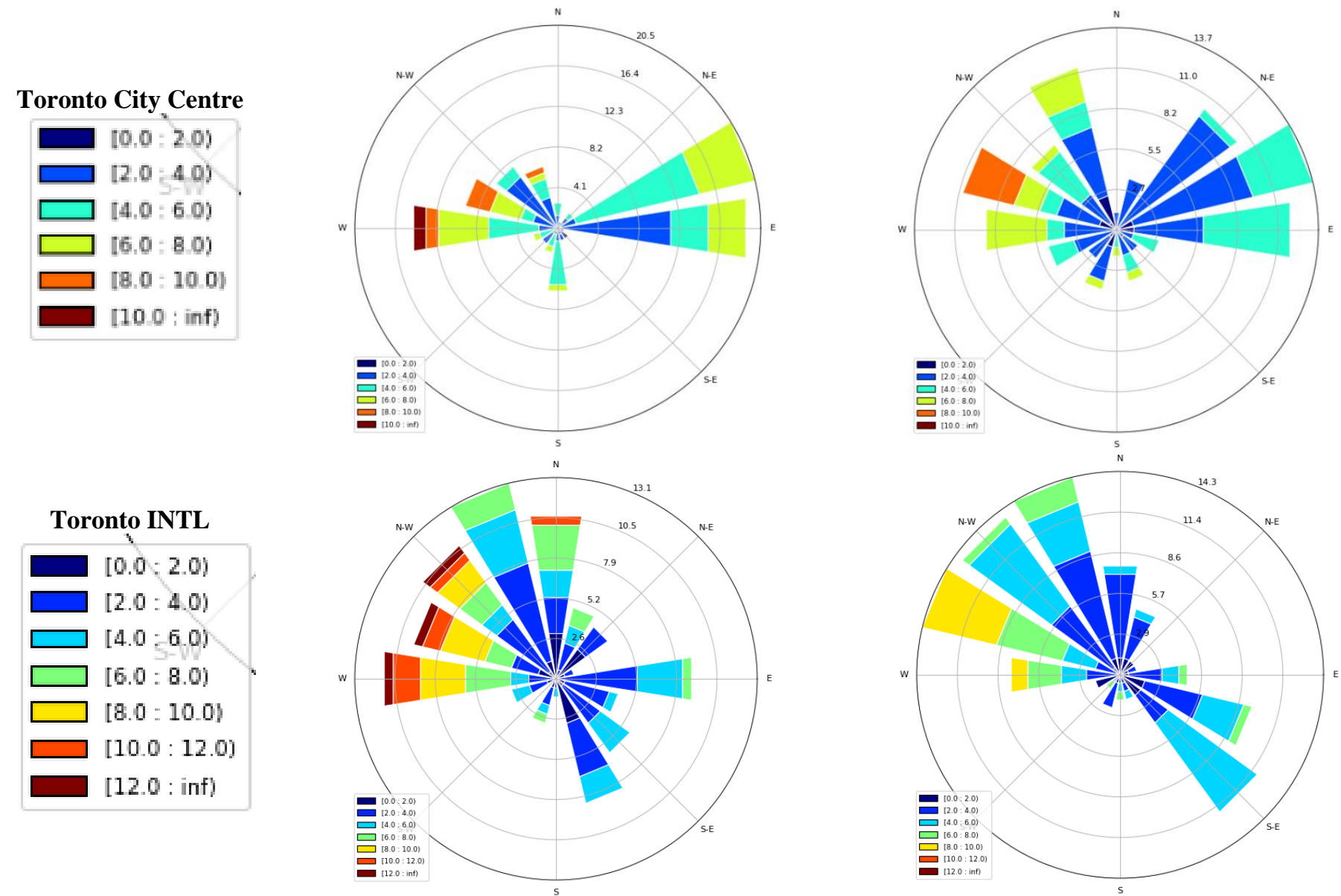

Table S5 Wind roses based on hourly measurements and WRF simulations at 7 weather stations located within the GTHA for the week of August $14^{\text {th }}$ to $20^{\text {th }}, 2016(\mathrm{~km} / \mathrm{h})$

Meteorological Station

\section{Burlington Piers}

$\square[0.0 ; 2.0)$
$[2.0: 4.0)$
$\square[4.0 ; 6.0)$
$\square[6.0: 8.0)$
$\square[8.0 ;$ inf]
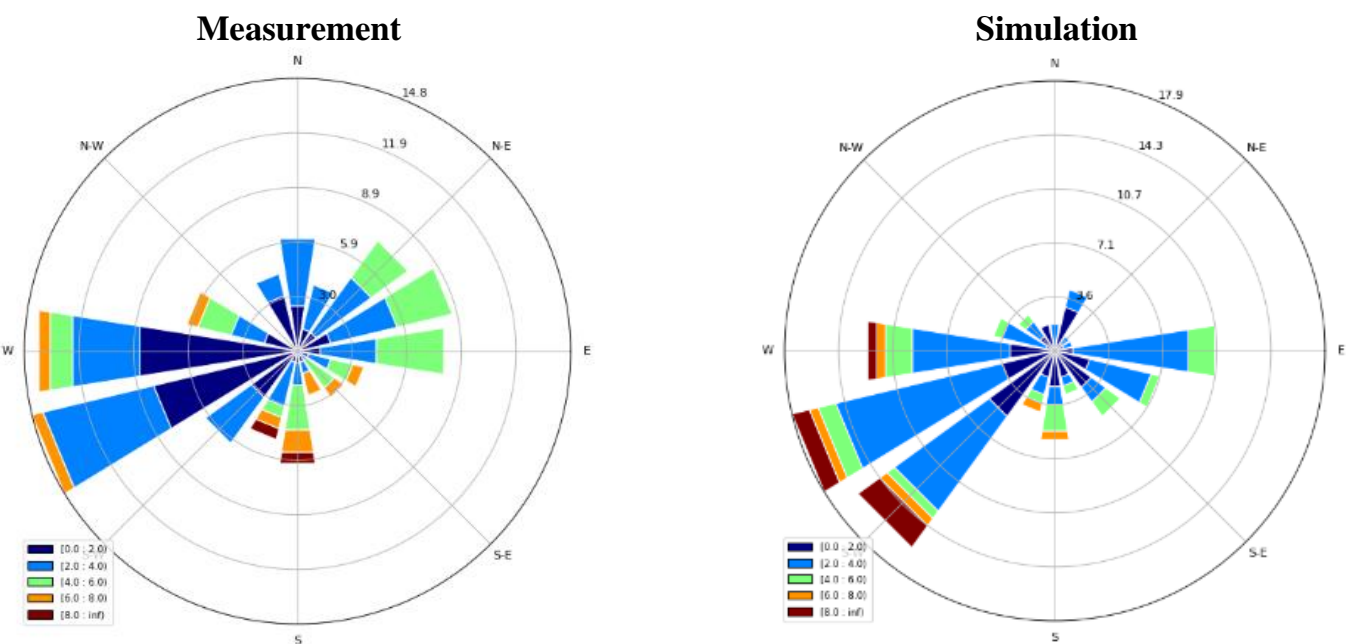

S14 


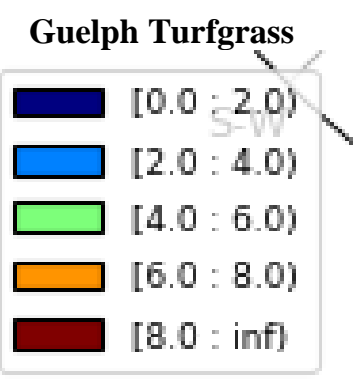

\section{Hamilton}

\begin{tabular}{|}
$\square[0.0=2.0]$ \\
$\square[2.0=4.0]$ \\
$\square[4.0=6.0]$ \\
$\square[6.0=8.0]$ \\
$\square[8.0=$ inf]
\end{tabular}

Kitchener Waterloo

$\square[0.0 ; 2.0)$
$[2.0 ; 4.0)$
$\square[4.0 ; 6.0)$
$\square[6.0 ; 8.0)$
$\square[8.0 ; 10.0)$
$\square$ [10.0:12.0)
$\square$ [12.0: inf)
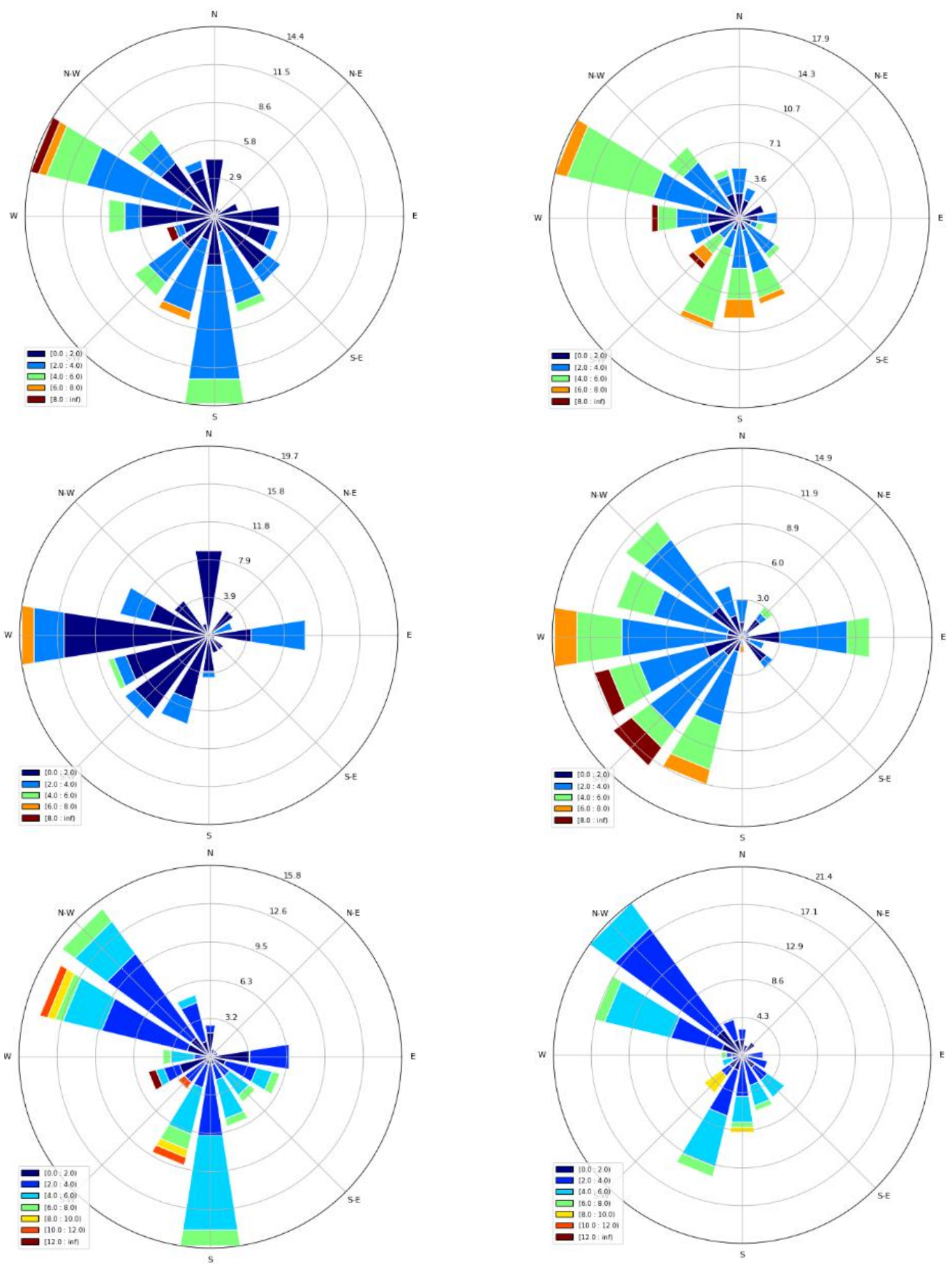


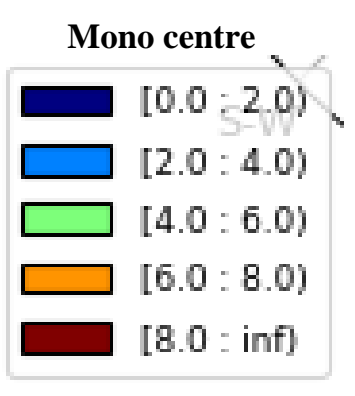

Toronto City Centre

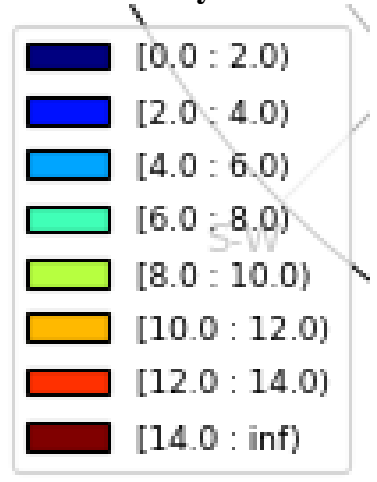

Toronto INTL

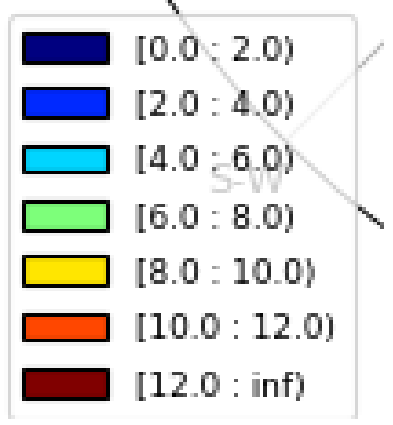

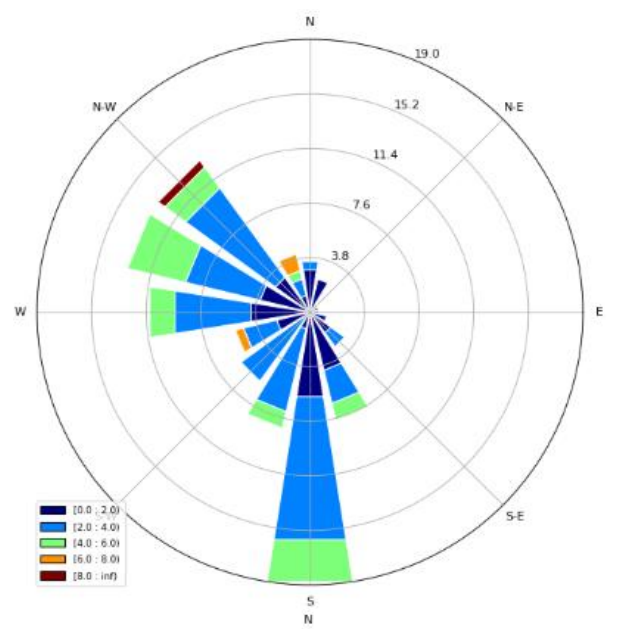
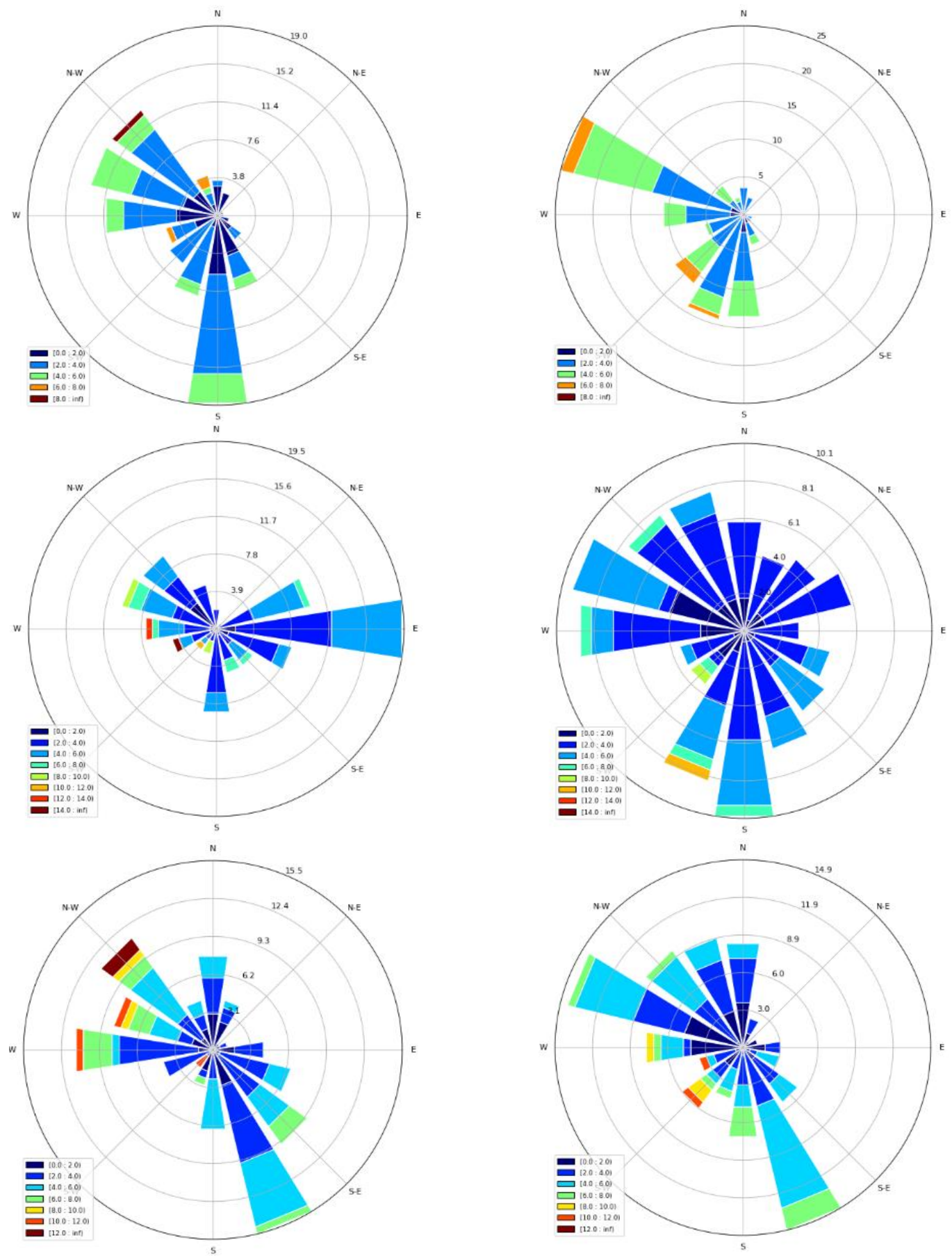
Table S6 Wind roses based on hourly measurements and WRF simulations at 7 weather stations located within the GTHA for the week of November $27^{\text {th }}$ to December $3^{\text {rd }}, 2016(\mathrm{~km} / \mathrm{h})$

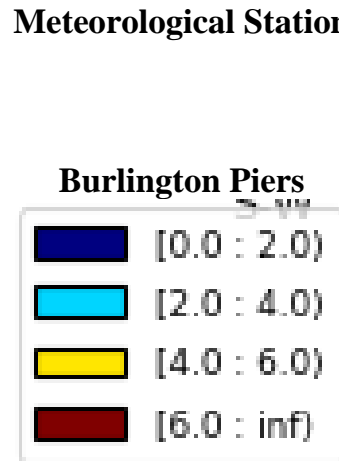

\section{Guelph Turfgrass

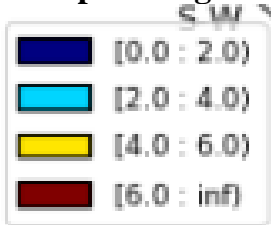

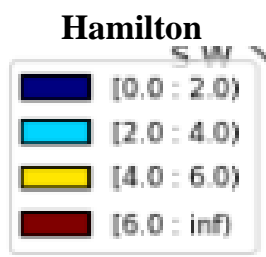
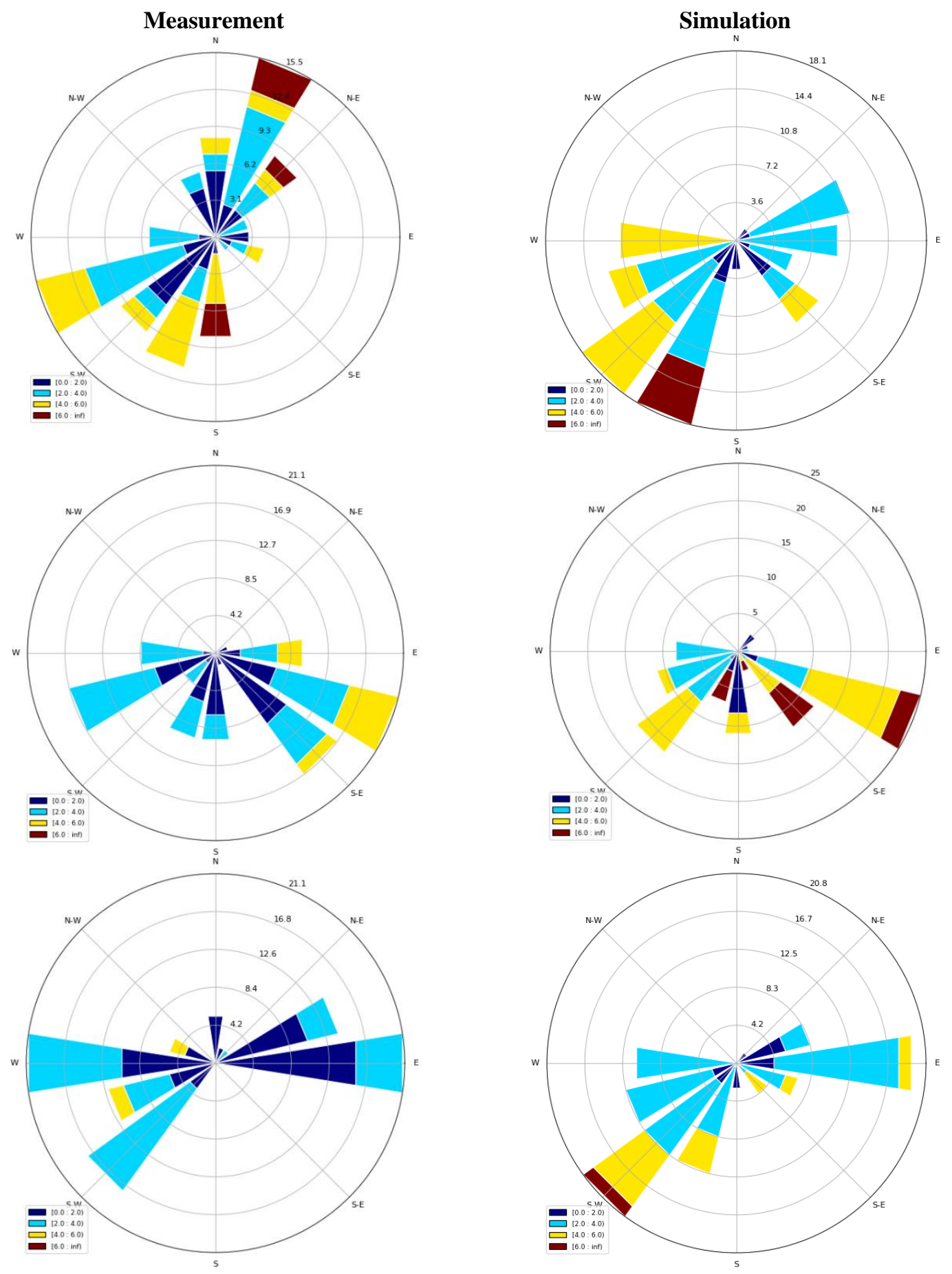
Kitchener Waterloo

$[0.0 ; 20)$

$\square[2.0 ; 4.0)$

$\square[4.0 ; 6.0$ )

$\square[6.0: 8.0)$

$\square[8.0$; inf]

Mono centre

$\square[0.0 ; 20)$
$\square[2.0 \div 4.0)$
$\square[4.0 ; 6.0)$
$\square[6.0 ; 8.0)$
$\square[8.0 ;$ inf]

Toronto City Centre

\begin{tabular}{|c|c|}
\hline \multicolumn{2}{|l|}{$[0.0=2.0)$} \\
\hline$[2.0 ; 4.0)$ & \\
\hline$[4.0 \div 6.0)$ & \\
\hline$[6.0 ; 8.0)$ & \\
\hline$[8.0: 10.0]$ & \\
\hline$[10.0 ;$ inf) & \\
\hline
\end{tabular}
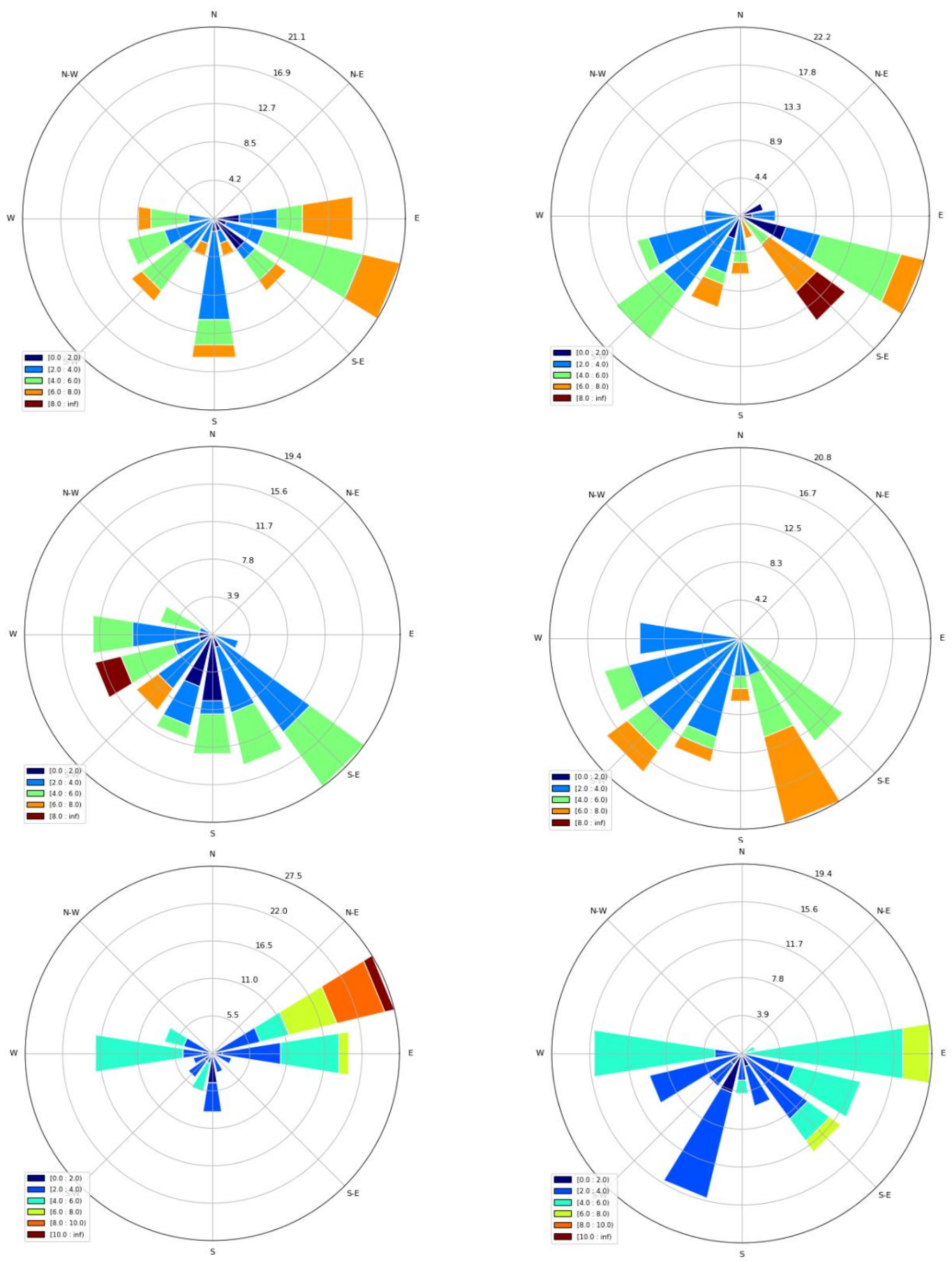


\section{Toronto INTL}

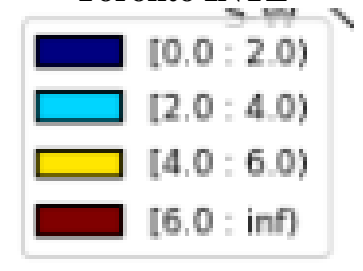

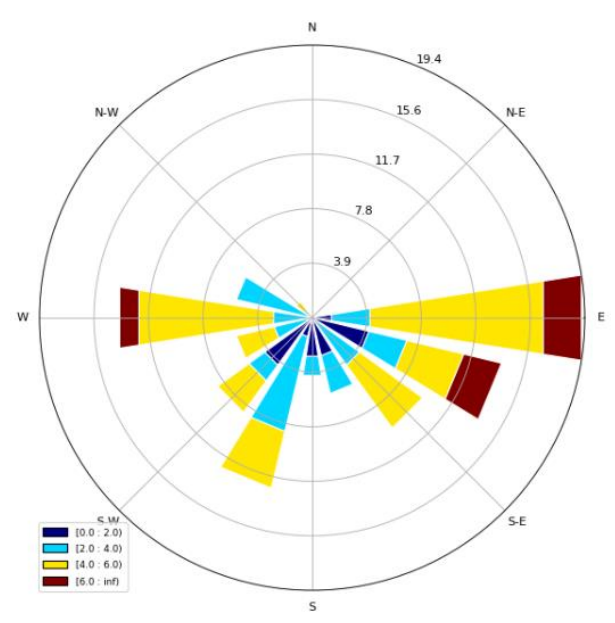

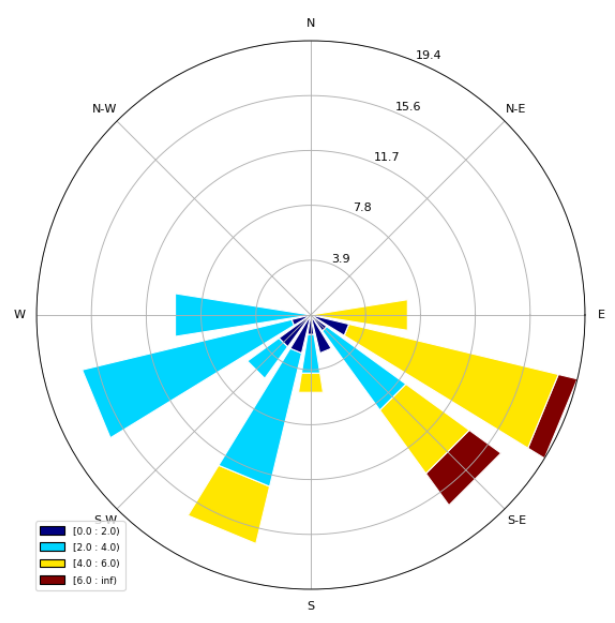

\subsection{Initial and boundary conditions}

We adjusted the ozone $\left(\mathrm{O}_{3}\right)$, nitrogen dioxide $\left(\mathrm{NO}_{2}\right)$ and nitric oxide $(\mathrm{NO})$ concentrations initial and boundary conditions extracted from MOZART4 using data collected at 18 monitoring stations in the GTHA (Figure S6). We focused solely on these three pollutants since these are criteria air contaminants (CAC) that are regulated and systematically measured at regulatory monitoring stations. We did not adjust the simulations of $\mathrm{PM}_{2.5}$ because we did not have access to detailed speciation profiles at the monitoring stations.

MOZART4 simulated concentrations over periods of 6h (12-6am, 6am-12pm, 12-6pm, 6pm$12 \mathrm{am})$. We adjusted the initial and boundary conditions as follows:

1) For each time period of the four weeks simulated, we averaged the hourly concentrations of $\mathrm{O}_{3}, \mathrm{NO}_{2}$, and $\mathrm{NO}$ recorded at the monitoring stations. In parallel, we determined the concentrations simulated by MOZART4 at each of these monitoring stations for each time period of the four weeks.

2) For each pollutant and each time period, we calculated the average ratio of measured to simulated concentrations (Tables S7 to S10).

3) We multiplied the hourly initial and boundary conditions of $\mathrm{NO}_{2}, \mathrm{NO}$ and $\mathrm{O}_{3}$ determined with MOZART 4 by the average ratio calculated for each time period. 


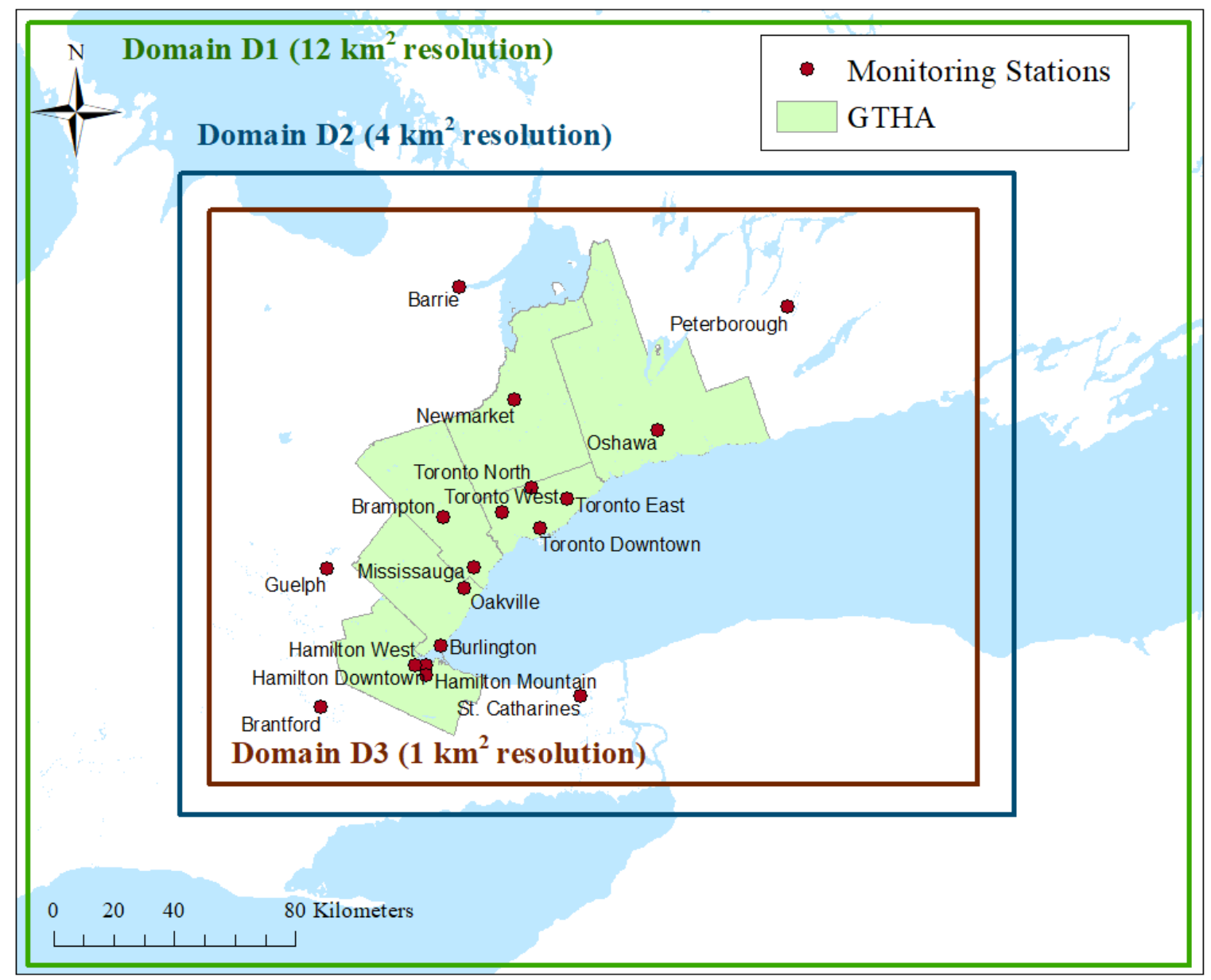

Figure S6 Monitoring stations used to correct the initial and boundary conditions and to validate the simulations

Table $\mathrm{S}_{7} \mathrm{NO}_{2}$, $\mathrm{NO}$ and $\mathrm{O}_{3}$ average measured and simulated (MOZART4) concentrations at the monitoring stations for the week of March $20^{\text {th }}$ to $26^{\text {th }}, 2016$

\begin{tabular}{|c|l|c|c|c|c|}
\hline Pollutant & \multicolumn{1}{|c|}{ Variable } & 12-6am & 6am-12pm & 12-6pm & 6pm-12am \\
\hline \multirow{3}{*}{ NO$_{2}$} & Average Measured Concentration $\left(\mu \mathrm{gg} / \mathrm{m}^{3}\right)$ & 35.4 & 24.5 & 13.5 & 24.7 \\
\cline { 2 - 6 } & Average Simulated Concentration $\left(\mu \mathrm{g} / \mathrm{m}^{3}\right)$ & 7.8 & 13.0 & 10.6 & 4.8 \\
\cline { 2 - 6 } & Average Ratio (Measured/Simulated) & 5.6 & 1.9 & 1.3 & 8.9 \\
\hline \multirow{3}{*}{$\mathbf{O}_{3}$} & Average Measured Concentration $\left(\mu \mathrm{g} / \mathrm{m}^{3}\right)$ & 35.1 & 50.7 & 70.0 & 56.3 \\
\cline { 2 - 6 } & Average Simulated Concentration $\left(\mu \mathrm{g} / \mathrm{m}^{3}\right)$ & 106.6 & 85.9 & 81.8 & 106.6 \\
\cline { 2 - 6 } & Average Ratio (Measured/Simulated) & 0.3 & 0.6 & 0.9 & 0.5 \\
\hline \multirow{3}{*}{ NO } & Average Measured Concentration $\left(\mu \mathrm{g} / \mathrm{m}^{3}\right)$ & 4.3 & 1.7 & 1.1 & 5.3 \\
\cline { 2 - 6 } & Average Simulated Concentration $\left(\mu \mathrm{g} / \mathrm{m}^{3}\right)$ & 0.3 & 0.1 & 0.1 & 0.2 \\
\cline { 2 - 6 } & Average Ratio (Measured/Simulated) & 20.8 & 6.5 & 4.7 & 49.1 \\
\hline
\end{tabular}


Table $\mathrm{S8} \mathrm{NO}_{2}$, $\mathrm{NO}$ and $\mathrm{O}_{3}$ average measured and simulated (MOZART4) concentrations at the monitoring stations for the week of May $8^{\text {th }}$ to $14^{\text {th }}, 2016$

\begin{tabular}{|c|l|c|c|c|c|}
\hline Pollutant & \multicolumn{1}{|c|}{ Variable } & 12-6am & 6am-12pm & 12-6pm & 6pm-12am \\
\hline \multirow{3}{*}{ NO$_{2}$} & Average Measured Concentration $\left(\mu \mathrm{g} / \mathrm{m}^{3}\right)$ & 19.4 & 15.7 & 8.4 & 15.4 \\
\cline { 2 - 6 } & Average Simulated Concentration $\left(\mu \mathrm{g} / \mathrm{m}^{3}\right)$ & 7.0 & 12.9 & 8.8 & 2.2 \\
\cline { 2 - 6 } & Average Ratio (Measured/Simulated) & 2.9 & 1.2 & 1.1 & 10.4 \\
\hline \multirow{3}{*}{$\mathbf{O}_{3}$} & Average Measured Concentration $\left(\mu \mathrm{g} / \mathrm{m}^{3}\right)$ & 43.0 & 54.0 & 73.5 & 62.3 \\
\cline { 2 - 6 } & Average Simulated Concentration $\left(\mu \mathrm{g} / \mathrm{m}^{3}\right)$ & 99.9 & 72.2 & 73.0 & 104.8 \\
\cline { 2 - 6 } & Average Ratio (Measured/Simulated) & 0.4 & 0.8 & 1.0 & 0.6 \\
\hline \multirow{3}{*}{ NO } & Average Measured Concentration $\left(\mu \mathrm{g} / \mathrm{m}^{3}\right)$ & 4.7 & 4.9 & 2.0 & 2.1 \\
\cline { 2 - 6 } & Average Simulated Concentration $\left(\mu \mathrm{g} / \mathrm{m}^{3}\right)$ & 0.1 & 0.0 & 1.0 & 0.3 \\
\cline { 2 - 6 } & Average Ratio (Measured/Simulated) & 35.9 & 118.6 & 2.7 & 7.7 \\
\hline
\end{tabular}

Table $\mathrm{S} \mathrm{NO}_{2}, \mathrm{NO}$ and $\mathrm{O}_{3}$ average measured and simulated (MOZART4) concentrations at the monitoring stations for the week of August $14^{\text {th }}$ to $20^{\text {th }}, 2016$

\begin{tabular}{|c|l|c|c|c|c|}
\hline Pollutant & \multicolumn{1}{|c|}{ Variable } & 12-6am & 6am-12pm & 12-6pm & 6pm-12am \\
\hline \multirow{3}{*}{ NO$_{2}$} & Average Measured Concentration $\left(\mu \mathrm{g} / \mathrm{m}^{3}\right)$ & 14.6 & 15.6 & 9.6 & 12.6 \\
\cline { 2 - 6 } & Average Simulated Concentration $\left(\mu \mathrm{g} / \mathrm{m}^{3}\right)$ & 6.2 & 12.6 & 9.8 & 1.6 \\
\cline { 2 - 6 } & Average Ratio (Measured/Simulated) & 2.5 & 1.4 & 1.1 & 9.9 \\
\hline \multirow{3}{*}{$\mathbf{O}_{3}$} & Average Measured Concentration $\left(\mu \mathrm{g} / \mathrm{m}^{3}\right)$ & 34.4 & 47.2 & 82.1 & 68.0 \\
\cline { 2 - 6 } & Average Simulated Concentration $\left(\mu \mathrm{g} / \mathrm{m}^{3}\right)$ & 133.3 & 99.4 & 88.1 & 130.7 \\
\cline { 2 - 6 } & Average Ratio (Measured/Simulated) & 0.3 & 0.5 & 0.9 & 0.5 \\
\hline \multirow{3}{*}{ NO } & Average Measured Concentration $\left(\mu \mathrm{g} / \mathrm{m}^{3}\right)$ & 3.1 & 5.4 & 1.7 & 1.0 \\
\cline { 2 - 6 } & Average Simulated Concentration $\left(\mu \mathrm{g} / \mathrm{m}^{3}\right)$ & 0.0 & 0.0 & 0.7 & 0.1 \\
\cline { 2 - 6 } & Average Ratio (Measured/Simulated) & 78.3 & 278.5 & 3.9 & 6.9 \\
\hline
\end{tabular}

Table $\mathrm{S}_{10} \mathrm{NO}_{2}$, NO and $\mathrm{O}_{3}$ average measured and simulated (MOZART4) concentrations at the monitoring stations for the week of November $27^{\text {th }}$ to December $3^{\text {rd }}, 2016$

\begin{tabular}{|c|l|c|c|c|c|}
\hline Pollutant & \multicolumn{1}{|c|}{ Variable } & 12-6am & 6am-12pm & 12-6pm & 6pm-12am \\
\hline \multirow{3}{*}{ NO$_{2}$} & Average Measured Concentration $\left(\mu \mathrm{g} / \mathrm{m}^{3}\right)$ & 15.9 & 18.2 & 16.6 & 22.4 \\
\cline { 2 - 6 } & Average Simulated Concentration $\left(\mu \mathrm{g} / \mathrm{m}^{3}\right)$ & 14.3 & 12.6 & 11.6 & 7.3 \\
\cline { 2 - 6 } & Average Ratio (Measured/Simulated) & 1.3 & 1.7 & 1.6 & 3.8 \\
\hline \multirow{3}{*}{$\mathbf{O}_{3}$} & Average Measured Concentration $\left(\mu \mathrm{g} / \mathrm{m}^{3}\right)$ & 31.3 & 30.7 & 37.9 & 29.2 \\
\cline { 2 - 6 } & Average Simulated Concentration $\left(\mu \mathrm{g} / \mathrm{m}^{3}\right)$ & 50.4 & 50.1 & 49.6 & 62.9 \\
\cline { 2 - 6 } & Average Ratio (Measured/Simulated) & 0.7 & 0.6 & 0.8 & 0.5 \\
\hline \multirow{3}{*}{ NO } & Average Measured Concentration $\left(\mu \mathrm{g} / \mathrm{m}^{3}\right)$ & 8.3 & 7.2 & 4.5 & 5.1 \\
\cline { 2 - 6 } & Average Simulated Concentration $\left(\mu \mathrm{g} / \mathrm{m}^{3}\right)$ & 0.1 & 0.1 & 0.1 & 1.5 \\
\cline { 2 - 6 } & Average Ratio (Measured/Simulated) & 136.6 & 107.5 & 94.8 & 4.2 \\
\hline
\end{tabular}




\subsection{Discretization and speciation of the PM emissions}

We discretized particulate matter (PM) into 5 bins with the following cutting diameters (in $\mu \mathrm{m}$ ): $0.01,0.0398,0.1585,0.6310,2.5119$ and 10. The first four bins (later identified with the subscripts 0 to 3 ) correspond to $\mathrm{PM}_{2.5}$, and the last bin (later identified with the subscript 4) refers to $\mathrm{PM}_{\text {coarse. }}$

PM emissions were speciated into organic aerosol (OA), black carbon (BC), and mineral dust (MD) depending on the source of emissions. Emission sources were divided into 10 SNAP (Selected Nomenclature for Air Pollution) sectors:

- Combustion in Energy and Transformation Industries (1)

- Non-Industrial Combustion Plants (2)

- Combustion in Manufacturing Industry (3)

- Production Processes (4)

- Extraction and Distribution of Fossil Fuels and Geothermal Energy (5)

- Solvent and Other Product Use (6)

- $\quad$ Road Transport (7)

- Other Mobile Sources and Machinery (8)

- Waste Treatment and Disposal (9)

- Agriculture (10)

The speciation for sectors 1 to 6 and 8 to 10 (i.e., all sectors except sector 7 - Road Transport) was provided by EMEP/EDGAR. Emissions from sector 7 were differentiated between exhaust, brake and tire wear. Exhaust emissions follow the speciation from Smyth et al. ${ }^{3}$, where the CTM AURAMS was applied in Canada. The speciation of tire wear and brake PM emissions was based on the study of Simons. ${ }^{4}$ Table S11 summarizes the speciation factors. 
Table S11 Speciation of the emissions of PM2.5, and PMcarse for the different SNAP sectors. The factors represent the percentage of emissions of each pollutant attributed to each sub-pollutant. PPOA, PBC and PMD refer to Particulate Primary Organic Aerosol (POA), Black Carbon (BC) and Mineral Dust (MD).

\begin{tabular}{|l|c|c|c|c|c|c|c|c|c|c|c|c|}
\hline Source & \multicolumn{9}{|c|}{ EMEP/EDGAR } \\
\hline SNAP sector & 1 & 2 & 3 & 4 & 5 & 6 & 8 & 9 & 10 & 7 (exhaust) & 7 (tire) & 7 (brake) \\
\hline PPOA_0 & 1 & 2.475 & 3.75 & 2.475 & 0 & 3 & 2.55 & 3 & 0.75 & 2.55 & 6.8 & 3.9 \\
\hline PPOA_1 & 1 & 8.085 & 12.25 & 8.085 & 0 & 9.8 & 8.33 & 9.8 & 2.45 & 8.33 & 13.6 & 7.8 \\
\hline PPOA_2 & 1 & 11.22 & 17 & 11.22 & 0 & 13.6 & 11.56 & 13.6 & 3.4 & 11.56 & 13.6 & 2.8 \\
\hline PPOA_3 & 1 & 11.22 & 17 & 11.22 & 0 & 13.6 & 11.56 & 13.6 & 3.4 & 11.56 & 33.2 & 2.8 \\
\hline PPOA_4 & 1 & 0 & 0 & 0 & 0 & 0 & 0 & 0 & 0 & 0 & 0 & 0 \\
\hline PBC_0 & 1 & 2.475 & 1.5 & 2.475 & 1.5 & 3.75 & 4.2 & 1.5 & 4.5 & 4.2 & 2.9 & 1.0 \\
\hline PBC_1 & 1 & 8.085 & 4.9 & 8.085 & 4.9 & 12.25 & 13.72 & 4.9 & 14.7 & 13.72 & 5.8 & 1.3 \\
\hline PBC_2 & 1 & 11.22 & 6.8 & 11.22 & 6.8 & 17 & 19.04 & 6.8 & 20.4 & 19.04 & 5.8 & 0.7 \\
\hline PBC_3 & 1 & 11.22 & 6.8 & 11.22 & 6.8 & 17 & 19.04 & 6.8 & 20.4 & 19.04 & 14.1 & 0.7 \\
\hline PBC_4 & 1 & 0 & 0 & 0 & 0 & 0 & 0 & 0 & 0 & 0 & 0 & 0 \\
\hline PMD_0 & 1 & 0 & 0 & 0 & 0 & 0 & 0 & 0 & 0 & 0 & 0 & 0 \\
\hline PMD_1 & 1 & 6.6 & 6 & 6.6 & 16 & 2 & 2 & 8 & 6 & 2 & 0.6 & 16.3 \\
\hline PMD_2 & 1 & 13.2 & 12 & 13.2 & 32 & 4 & 4 & 16 & 12 & 4 & 1.3 & 32.6 \\
\hline PMD_3 & 1 & 13.2 & 12 & 13.2 & 32 & 4 & 4 & 16 & 12 & 4 & 2.3 & 32.6 \\
\hline PMD_4 & 1 & 0 & 0 & 0 & 0 & 0 & 0 & 0 & 0 & 0 & 0 & 0 \\
\hline
\end{tabular}

\subsection{Traffic emissions outside the GTHA}

Our detailed traffic-related emission inventory provided emissions for the grid cells located within the GTHA. Outside the GTHA, we adjusted the road-transport emissions from EDGAR4.3.1 inventory (sector 7, see section SI 1.5) using factors calculated based on a comparison of EDGAR4.3.1 emissions and ours in the grid cells in common. This had two major advantages:

1) We were able to derive separate emission inventories for private passenger vehicles, commercial vehicles, and transit buses, even if EDGAR4.3.1 only provides total on-road transport emissions. We could then adjust the emissions of each vehicle category for each scenario considered.

2) We ensured that the magnitude of the emissions outside the GTHA and derived from EDGAR4.3.1 was in alignment with the magnitude of the emissions from our inventory within the GTHA.

\subsection{Replacement of the diesel truck fleet}

Under scenario S3 (Cleaner Trucks), we replaced all commercial vehicles older than 8 years by newer models. We redistributed the old vehicles evenly over the eight newest age bins. Table S12 shows the current fleet distribution of commercial vehicles (used in all study cases and 
scenarios except S3), as well as the modified fleet implemented in S3. Under S3, we distributed equally the newer trucks over 8 years because we assume no scrappage policy would be implemented within a single year.

Table S12 Age distribution of the current fleet of commercial vehicles (as of 2016) and the fleet implemented in the simulation $\mathrm{S3}$

\begin{tabular}{|c|c|c|}
\hline Age & Current fleet (in \%) & Fleet in S3 (in \%) \\
\hline 0 & 0.0687 & 0.114271 \\
\hline 1 & 0.0687 & 0.114271 \\
\hline 2 & 0.0687 & 0.114271 \\
\hline 3 & 0.0757 & 0.125915 \\
\hline 4 & 0.0757 & 0.125915 \\
\hline 5 & 0.0757 & 0.125915 \\
\hline 6 & 0.056 & 0.093147 \\
\hline 7 & 0.056 & 0.093147 \\
\hline 8 & 0.056 & 0.093147 \\
\hline 9 & 0.03 & 0 \\
\hline 10 & 0.03 & 0 \\
\hline 11 & 0.03 & 0 \\
\hline 12 & 0.03 & 0 \\
\hline 13 & 0.03 & 0 \\
\hline 14 & 0.03 & 0 \\
\hline 15 & 0.03 & 0 \\
\hline 16 & 0.03 & 0 \\
\hline 17 & 0.03 & 0 \\
\hline 18 & 0.03 & 0 \\
\hline 19 & 0.0099 & 0 \\
\hline 20 & 0.0099 & 0 \\
\hline 21 & 0.0099 & 0 \\
\hline 22 & 0.0099 & 0 \\
\hline 23 & 0.0099 & 0 \\
\hline 24 & 0.0099 & 0 \\
\hline 25 & 0.0099 & 0 \\
\hline 26 & 0.0099 & 0 \\
\hline 27 & 0.0099 & 0 \\
\hline 28 & 0.0097 & 0 \\
\hline 29 & 0 & 0 \\
\hline 30 & 0 & 0 \\
\hline
\end{tabular}




\subsection{Power plant emissions}

The NPRI database ${ }^{5}$ for Ontario, and the U.S. EPA National Emission Inventory (NEI) ${ }^{6}$ for New York State (NYS) did not provide comprehensive emissions of $\mathrm{NH}_{3}, \mathrm{CO}, \mathrm{NO}_{\mathrm{x}}, \mathrm{PM}_{10}, \mathrm{PM}_{2.5}, \mathrm{SO}_{2}$ and NMVOC for power plants. We estimated the emission factors (EFs) of each power plant as in equation (1).

$$
E F=\frac{\text { annual emissions }}{\text { annual power generation }}
$$

Tables S13 and S14 present the EFs for the Ontario and U.S. power plants; cells in italic red indicate missing information that was completed. In Table S14, COAL\&PET refer to coal and petroleum, GAS\&PET to gas and petroleum, and GAS to natural gas power plants. For all pollutants except $\mathrm{SO}_{2}$ in Ontario, we derived the missing EFs (i.e., for the power plants and pollutants for which detailed information was not available) using linear regressions based on the EFs and generation capacity of the other power plants of the region (respecting the type of power plant). For $\mathrm{SO}_{2}$ in Ontario, the only data available was for the Lennox power plant and translated into a high EF compared to those of GAS power plants from the U.S.; we thus used the average $\mathrm{SO}_{2} \mathrm{EF}$ from GAS U.S. power plants for Ontarian power plants.

For GHG emissions, we extracted the direct $\mathrm{CO}_{2}, \mathrm{CH}_{4}$ and $\mathrm{N}_{2} \mathrm{O}$ emissions (2016) from the national Greenhouse Gas Reporting Program (GHGRP) ${ }^{7}$ for each power plant located in Ontario, and applied recent global warming potential $(\mathrm{GWP})^{8}$ values to convert $\mathrm{CH}_{4}$ and $\mathrm{N}_{2} \mathrm{O}$ emissions into $\mathrm{CO}_{2}$ equivalent. The GWP values are 30 and 265 for $\mathrm{CH}_{4}$ and $\mathrm{N}_{2} \mathrm{O}$, respectively (without climate carbon feedbacks). We then divided the total $\mathrm{CO}_{2}$ equivalent emissions by 2016 electricity outputs extracted from IESO $^{9}$ to calculate EFs for each power plant. To calculate the fuel cycle EFs (i.e., including upstream emissions associated with material transportation and storage), we used the average upstream emission factor of $40 \mathrm{~kg} \mathrm{CO} 2 \mathrm{eq} / \mathrm{MWh}$ provided by Mallia and Lewi, ${ }^{10}$ but adjusted the emissions by assuming a $1.7 \%$ methane leakage from natural gas extraction and delivery, ${ }^{11}$ rather than $0.25 \%$. 
Table S13 Emissions Factors (EFs) for the Ontarian power plants included in our domains. Cells in italic red highlight missing data that was completed.

\begin{tabular}{|c|c|c|c|c|c|c|c|c|c|}
\hline $\begin{array}{c}\text { Ontario Plant } \\
\text { IESO Name }\end{array}$ & $\begin{array}{c}\mathbf{N H}_{\mathbf{3}} \\
(\mathbf{g} / \mathbf{M W h})\end{array}$ & $\begin{array}{c}\mathbf{C O} \\
(\mathbf{g} / \mathbf{M W h})\end{array}$ & $\begin{array}{c}\mathbf{N O}_{\mathbf{x}} \\
(\mathbf{g} / \mathbf{M W h})\end{array}$ & $\begin{array}{c}\mathbf{P M}_{\mathbf{1 0}} \\
(\mathbf{g} / \mathbf{M W h})\end{array}$ & $\begin{array}{c}\mathbf{P M}_{\mathbf{2 . 5}} \\
(\mathbf{g} / \mathbf{M W h})\end{array}$ & $\begin{array}{c}\mathbf{S O}_{\mathbf{2}} \\
(\mathbf{g} / \mathbf{M W h})\end{array}$ & $\begin{array}{c}\mathbf{N M V O C} \\
(\mathbf{g} / \mathbf{M W h})\end{array}$ & $\begin{array}{c}\mathbf{G H G} \\
\text { fuel cycle } \\
(\mathbf{k g} / \mathbf{M W h})\end{array}$ & $\begin{array}{c}\text { Capacity } \\
(\mathbf{M W})\end{array}$ \\
\hline DESTEC & 12.6 & 154.1 & 163.7 & 8.2 & 8.2 & 3.8 & 56.8 & 509 & 140 \\
\hline GTAA & 12.6 & 1385.2 & 789.0 & 114.6 & 104.5 & 3.8 & 56.1 & 1052 & 128 \\
\hline HALTONHILLS & 12.6 & 52.3 & 177.6 & 1.9 & 1.9 & 3.8 & 90.9 & 494 & 757 \\
\hline LENNOX & 12.6 & 369.9 & 1537.9 & 3.9 & 3.9 & 2824.0 & 166.8 & 1302 & 2130 \\
\hline PORTLANDS & 12.6 & 269.7 & 251.6 & 6.0 & 6.0 & 3.8 & 84.4 & 461 & 639 \\
\hline $\begin{array}{c}\text { SITHE. } \\
\text { GOREWAY }\end{array}$ & 12.6 & 281.0 & 75.8 & 2.1 & 2.1 & 3.8 & 101.1 & 544 & 942 \\
\hline TADOUGLAS & 12.6 & 143.8 & 601.5 & 6.7 & 6.7 & 3.8 & 55.8 & 500 & 122 \\
\hline THOROLDCGS & 12.6 & 290.9 & 233.1 & 24.1 & 24.1 & 3.8 & 66.7 & 611 & 320 \\
\hline WHITBYCGS & 12.6 & 277.3 & 547.5 & 9.4 & 9.4 & 3.8 & 52.1 & 656 & 56 \\
\hline YORKCGS & 12.6 & 1482.8 & 411.4 & 21.4 & 21.4 & 3.8 & 74.7 & 678 & 464 \\
\hline
\end{tabular}

Table S14 Emissions Factors (EFs) for the U.S. power plants included in our domains. Italic red cells highlight missing data that was completed.

\begin{tabular}{|c|c|c|c|c|c|c|c|c|c|c|}
\hline $\begin{array}{c}\text { New York } \\
\text { State } \\
\text { Plants__ } \\
\text { ORIS } \\
\text { Code }\end{array}$ & Fuel Type & $\begin{array}{c}\mathbf{N H}_{3} \\
(\mathrm{~g} / \mathbf{M W h})\end{array}$ & $\underset{\text { (g/MWh }}{\text { CO }}$ & $\begin{array}{c}\mathbf{N O}_{\mathbf{x}} \\
(\mathbf{g} / \mathbf{M W h})\end{array}$ & $\begin{array}{c}\mathbf{P M}_{10} \\
(\mathrm{~g} / \mathrm{MWh})\end{array}$ & $\begin{array}{c}\mathbf{P M}_{2.5} \\
\text { (g/MWh) }\end{array}$ & $\begin{array}{c}\mathbf{S O}_{2} \\
(\mathrm{~g} / \mathbf{M W h})\end{array}$ & $\begin{array}{l}\text { NMVOC } \\
\text { (g/MWh) }\end{array}$ & $\begin{array}{c}\text { GHG } \\
\text { fuel cycle } \\
\text { (kg/MWh) }\end{array}$ & $\begin{array}{c}\text { Capacity } \\
\text { (MW) }\end{array}$ \\
\hline 2549 & COAL\&PET & 12.6 & 145.8 & 529.5 & 51.8 & 18.0 & 2790.4 & 17.5 & 1068 & 1336.5 \\
\hline 6082 & COAL\&PET & 12.6 & 185.5 & 844.7 & 51.8 & 18.0 & 2435.7 & 10.6 & 1068 & 1840.6 \\
\hline 50449 & GAS\&PET & 12.6 & 140.6 & 421.8 & 111.5 & 111.5 & 2.8 & 61.8 & 586 & 184.1 \\
\hline 50451 & GAS\&PET & 12.6 & 81.2 & 701.7 & 111.5 & 111.5 & 3.3 & 61.8 & 762 & 19.0 \\
\hline 54041 & GAS & 12.6 & 757.0 & 1237.0 & 111.5 & 111.5 & 4.1 & 61.8 & 753 & 135.0 \\
\hline 54131 & GAS & 12.6 & 395.0 & 472.2 & 111.5 & 111.5 & 3.5 & 61.8 & 732 & 40.0 \\
\hline 54593 & GAS\&PET & 12.6 & 110.9 & 545.2 & 111.5 & 111.5 & 2.8 & 61.8 & 605 & 38.0 \\
\hline
\end{tabular}

\subsection{Spare capacity of natural gas power plants in Ontario}

Figure S7 displays the spare capacity of the Ontario (ON) natural gas power plants as well as their export to New York State (NYS), based on data averaged over the 10 power plants in Ontario. The hourly charging profiles of EVs under the scenarios S1 (100\% EV), S1a (20\% EV) and $\mathrm{S} 1 \mathrm{~b}(50 \% \mathrm{EV})$ have been overlapped.

Since we assumed night charging for the EVs, i.e., charging starting at midnight, we can see a peak in electricity demand for EVs between 12 am and 1 am under S1, S1a and S1b, which is nevertheless lower than the spare capacity of ON power plants at that time. Electricity demand for EVs in the subsequent hours is negligible. This shows that power plants in Ontario have 
enough spare capacity to accommodate a complete electrification of the private vehicle fleet in the GTHA under the 2016 average grid mix of Ontario, which is $9 \%$ natural gas, $61 \%$ nuclear, $24 \%$ hydro, and $6 \%$ wind. $^{12}$

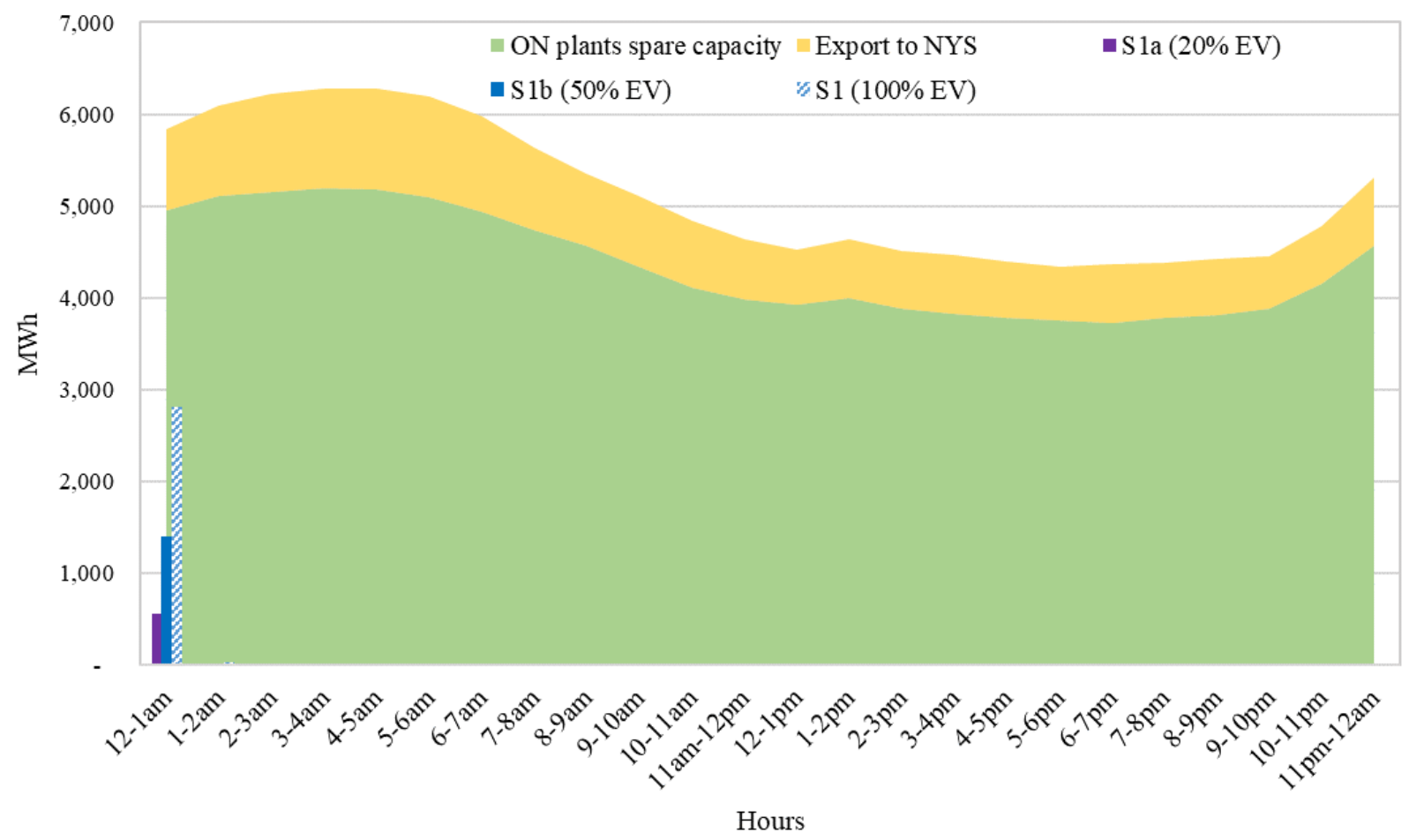

Figure S7 Hourly charging profile of EVs under the scenarios S1 (100\% EV), S1a (20\% EV) and S1b $(50 \% \mathrm{EV})$

\subsection{Energy consumption rate of battery electric buses (BEBs)}

We reviewed a number of studies aiming to assess the real-world energy consumption rate of BEBs, as summarized in Table S15. We decided to take the highest value, i.e. $170 \mathrm{kWh} / 100 \mathrm{~km}$, to consider the worst-case scenario.

Table S15 Energy consumption rates of battery electric buses (BEBs) estimated in different studies

\begin{tabular}{|c|c|c|}
\hline Study & $\begin{array}{c}\text { Energy consumption rate } \\
\text { (kWh/100km) }\end{array}$ & $\begin{array}{c}\text { Location of the study and source of the } \\
\text { consumption rate }\end{array}$ \\
\hline${\text { Zhou et al. }{ }^{13}}^{14}$ & 138 to 175 & Macao, China. Real-world conditions. \\
\hline${\text { Qin et al. }{ }^{14}}^{15}$ & 160 to 167 & $\begin{array}{c}\text { Tallahhassee, Florida. Real-world conditions vs } \\
\text { modeling. }\end{array}$ \\
\hline Gao et al. $^{15}$ & 135 & Knoxville, Tennessee. Modeling. \\
\hline Xylia et al. $^{16}$ & 150 & $\begin{array}{c}\text { Stockholm, Sweden. Adjusted for previous } \\
\text { estimates. }\end{array}$ \\
\hline
\end{tabular}




\section{RESULTS}

\subsection{Validation of the simulations}

We validated the concentrations of $\mathrm{NO}_{2}, \mathrm{O}_{3}$ and $\mathrm{PM}_{2.5}$ simulated against hourly records at 18 reference stations in the GTHA during the four weeks chosen $\left(20^{\text {th }}\right.$ to $26^{\text {th }}$ March, $8^{\text {th }}$ to $14^{\text {th }}$ May, and $14^{\text {th }}$ to $20^{\text {th }}$ August, $27^{\text {th }}$ November to $3^{\text {rd }}$ December). The performance indicators used include bias, which can be positive or negative and quantify the tendency of a model to under- or over-predict the observations, as well as errors, which indicate how a model deviates from the observations. ${ }^{17}$ Table S16 provides a description of the performance indicators, as well as the performance goals and criteria used for validation. Note that the Mean Normalized Bias Error (MNBE) and Mean Normalized Gross Error (MNGE) were only used for $\mathrm{O}_{3}$ and based on concentrations higher than $100 \mu \mathrm{g} / \mathrm{m}^{3}$, as suggested by U.S. EPA ${ }^{18}$, to ensure that the values obtained were not skewed due to low observations. ${ }^{17}$ The performance metrics used for $\mathrm{O}_{3}$, and $\mathrm{PM}_{2.5}$ and $\mathrm{NO}_{2}$, are different, because the Canadian Ambient Air Quality Standards (CAAQS) for these pollutants differ: while $\mathrm{O}_{3} \mathrm{CAAQS}$ focus on peak $\mathrm{O}_{3}$ concentrations (i.e., 8-hour averaged concentrations), $\mathrm{PM}_{2.5}$ and $\mathrm{NO}_{2}$ CAAQS are defined based on annual and/or daily averages.

Table S16 Description of the performance indicators and of the goals and criteria for validation of the base case simulation ${ }^{17,19}$

\begin{tabular}{|c|c|c|c|}
\hline \multicolumn{2}{|c|}{ Performance indicator } & \multirow{3}{*}{$\begin{array}{l}\text { Performance goal } \\
\text { As high as possible }\end{array}$} & \multirow[t]{2}{*}{ Performance criteria } \\
\hline & $\sum_{N}\left(C_{i, t}-\bar{C}\right)\left(O_{i, t}-\bar{O}\right)$ & & \\
\hline $\begin{array}{c}\text { Pearson Correlation } \\
\text { Coefficient }\end{array}$ & $\begin{array}{c}\sqrt{\sum_{N}\left(C_{i, t}-\bar{C}\right)^{2}} \sqrt{\sum_{N}\left(O_{i, t}-\bar{O}\right)^{2}} \\
\text { with } \bar{O}=\frac{1}{N} \sum_{N} O_{i, t} \text { and } \\
\bar{C}=\frac{1}{N} \sum_{N} C_{i, t}\end{array}$ & & I \\
\hline $\begin{array}{l}\text { RMSE: Root Mean } \\
\text { Square Error }\left(\mu \mathrm{g} / \mathrm{m}^{3}\right)\end{array}$ & $\sqrt{\frac{1}{\mathrm{~N}} \sum_{\mathrm{N}}\left(\mathrm{C}_{\mathrm{i}, \mathrm{t}}-\mathrm{O}_{\mathrm{i}, \mathrm{t}}\right)^{2}}$ & As low as possible & I \\
\hline $\begin{array}{c}\text { MNBE: Mean } \\
\text { Normalized Bias Error } \\
(\%)\end{array}$ & $\frac{1}{N} \sum_{N} \frac{C_{i, t}-O_{i, t}}{O_{i, t}} * 100$ & I & $\leq \pm 15 \%$ \\
\hline $\begin{array}{c}\text { MNGE: Mean } \\
\text { Normalized Gross Error } \\
(\%)\end{array}$ & $\frac{1}{N} \sum_{N} \frac{\left|\mathrm{C}_{\mathrm{i}, \mathrm{t}}-\mathrm{O}_{\mathrm{i}, \mathrm{t}}\right|}{\mathrm{O}_{\mathrm{i}}} * 100$ & I & $\leq \pm 30 \%$ \\
\hline $\begin{array}{c}\text { MFB: Mean Fractional } \\
\text { Bias }(\%)\end{array}$ & $\frac{2}{\mathrm{~N}} \sum_{\mathrm{N}} \frac{\mathrm{C}_{\mathrm{i}, \mathrm{t}}-\mathrm{O}_{\mathrm{i}, \mathrm{t}}}{\mathrm{C}_{\mathrm{i}, \mathrm{t}}+\mathrm{O}_{\mathrm{i}, \mathrm{t}}} * 100$ & $\leq \pm 30 \%$ & $\leq \pm 60 \%$ \\
\hline $\begin{array}{c}\text { MFE: Mean Fractional } \\
\text { Error }(\%)\end{array}$ & $\frac{2}{N} \sum_{N} \frac{\left|C_{i, t}-O_{i, t}\right|}{C_{i, t}+O_{i, t}} * 100$ & $\leq \pm 50 \%$ & $\leq \pm 75 \%$ \\
\hline
\end{tabular}

$O_{i, t}$ and $C_{i, t}$ are the observed and the modeled concentrations at time $t$ and location $i$, respectively, and $N$ is the total number of time-location pairs.

Table S17 shows the results of the validation of the 4 weeks simulated. 
Table S17 Performance indicators for $\mathrm{O}_{3}, \mathrm{PM}_{2.5}$ and $\mathrm{NO}_{2}$ for the winter and summer simulations calculated based on the measurements and simulations at 18 monitoring stations

\begin{tabular}{|c|c|c|c|c|c|c|c|c|c|}
\hline & $\begin{array}{l}\text { lutant } \\
\text { ason) }\end{array}$ & $\begin{array}{c}\text { Observed } \\
\text { Mean } \\
\left(\mathbf{u g} / \mathbf{m}^{3}\right)\end{array}$ & $\begin{array}{c}\text { Simulated } \\
\text { Mean } \\
\left(\mu \mathrm{u} / \mathbf{m}^{3}\right)\end{array}$ & $\begin{array}{c}\text { Pearson } \\
(\%)\end{array}$ & $\begin{array}{l}\text { RMSE } \\
\left(\mu \mathrm{g} / \mathbf{m}^{3}\right)\end{array}$ & $\begin{array}{c}\text { MNBE } \\
(\%)\end{array}$ & $\underset{(\%)}{\text { MNGE }}$ & $\begin{array}{c}\text { MFB } \\
(\%)\end{array}$ & $\begin{array}{c}\text { MFE } \\
(\%)\end{array}$ \\
\hline & Winter & 55.6 & 57.0 & 46 & 22.7 & $-16 * *$ & 23 & 9 & 41 \\
\hline & Spring & 60.6 & 76.0 & 57 & 28.6 & 12 & 20 & 24 & 35 \\
\hline $\mathbf{O}_{3}$ & Summer & 58.2 & 93.7 & 45 & 53.7 & 13 & $32 * *$ & $47 *$ & $58^{*}$ \\
\hline & Fall & 31.5 & 33.8 & 46 & 19.4 & NA & NA & 12 & $53^{*}$ \\
\hline & Winter & 7.6 & 10.7 & 37 & 8.1 & NA & NA & $36 *$ & $64 *$ \\
\hline & Spring & 5.9 & 7.0 & 23 & 5.7 & NA & NA & 12 & $59 *$ \\
\hline $\mathbf{P M I}_{2.5}$ & Summer & 5.5 & 7.7 & -19 & 6.3 & NA & NA & 30 & $75^{*}$ \\
\hline & Fall & 7.5 & 14.3 & 52 & 9.8 & NA & NA & $60 *$ & $71^{*}$ \\
\hline & Winter & 21.9 & 15.5 & 34 & 20.2 & NA & NA & -28 & $71^{*}$ \\
\hline $\mathbf{N}$ & Spring & 17.2 & 12.8 & 57 & 14.4 & NA & NA & -29 & $72 *$ \\
\hline$N_{2}$ & Summer & 11.7 & 10.4 & 39 & 10.4 & NA & NA & -17 & $67 *$ \\
\hline & Fall & 19.7 & 21.7 & 66 & 12.4 & NA & NA & 11 & 48 \\
\hline
\end{tabular}

* for values not meeting the performance goals but meeting the performance criteria; ** for values not meeting the performance goals (if applicable) nor the criteria. See Table S14 for a description of the indicators. RMSE: Root Mean Square Error; MNBE: Mean Normalized Bias Error; MNGE: Mean Normalized Gross Error; MFB: Mean Fractional Bias; MFE: Mean Fractional Error.

\subsection{Base case}

Figure $\mathrm{S} 8$ presents maps of the base case concentrations of $\mathrm{NO}_{2}, \mathrm{BC}, \mathrm{PM}_{2.5}$ and $\mathrm{O}_{3}$. When not specified, the results presented are based on concentrations averaged over the four weeks simulated.

The highways can be distinguished by higher concentrations along them. The highest concentrations are experienced in the urban areas; there is a hotspot in Peel region, which corresponds to the airport. 


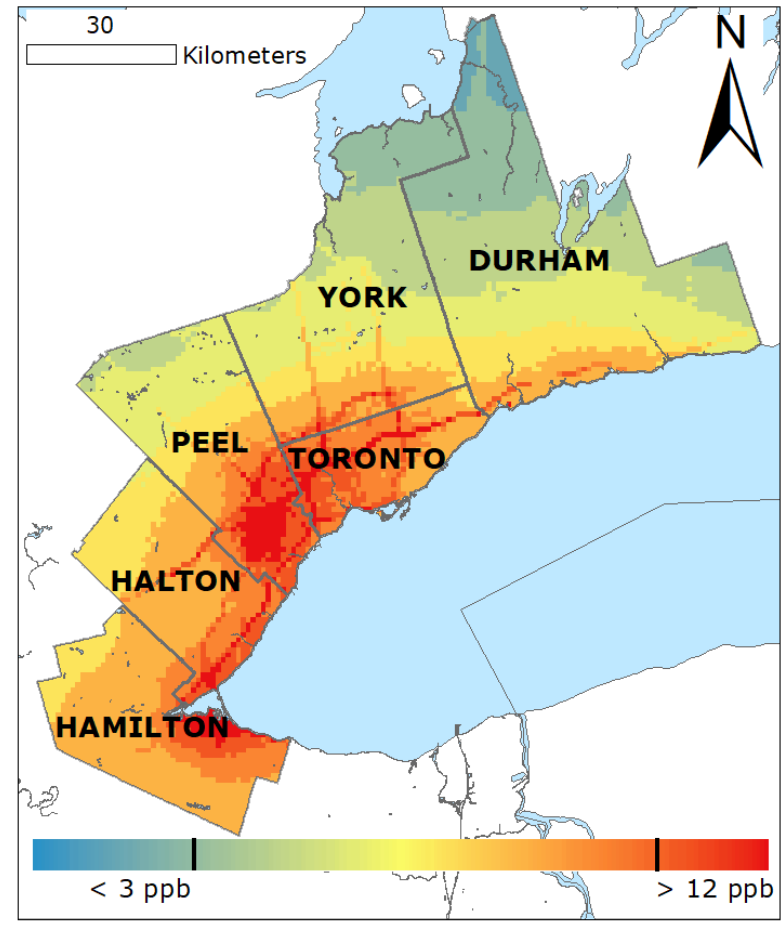

(a) $\mathrm{NO}_{2}$

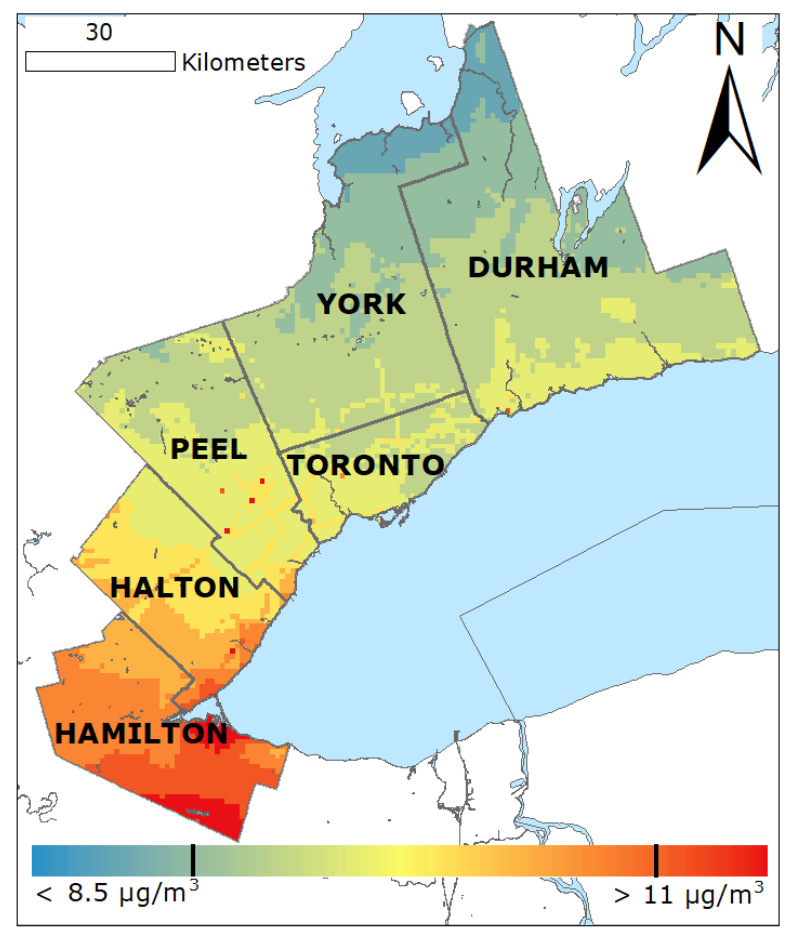

(c) $\mathbf{P M}_{2.5}$

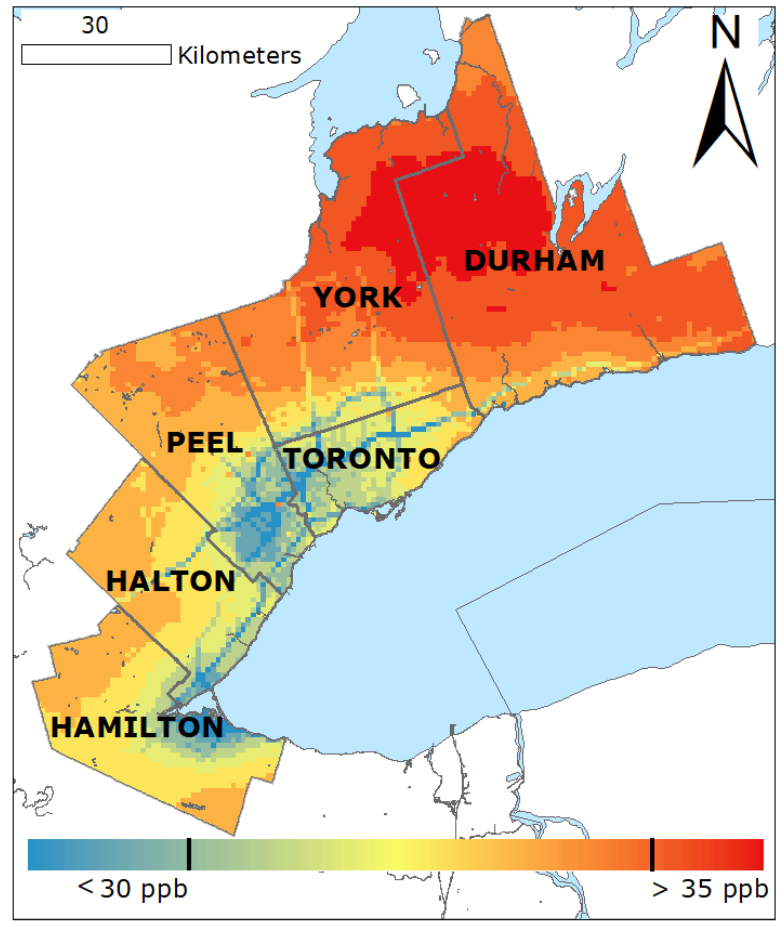

(b) $\mathrm{O}_{3}$

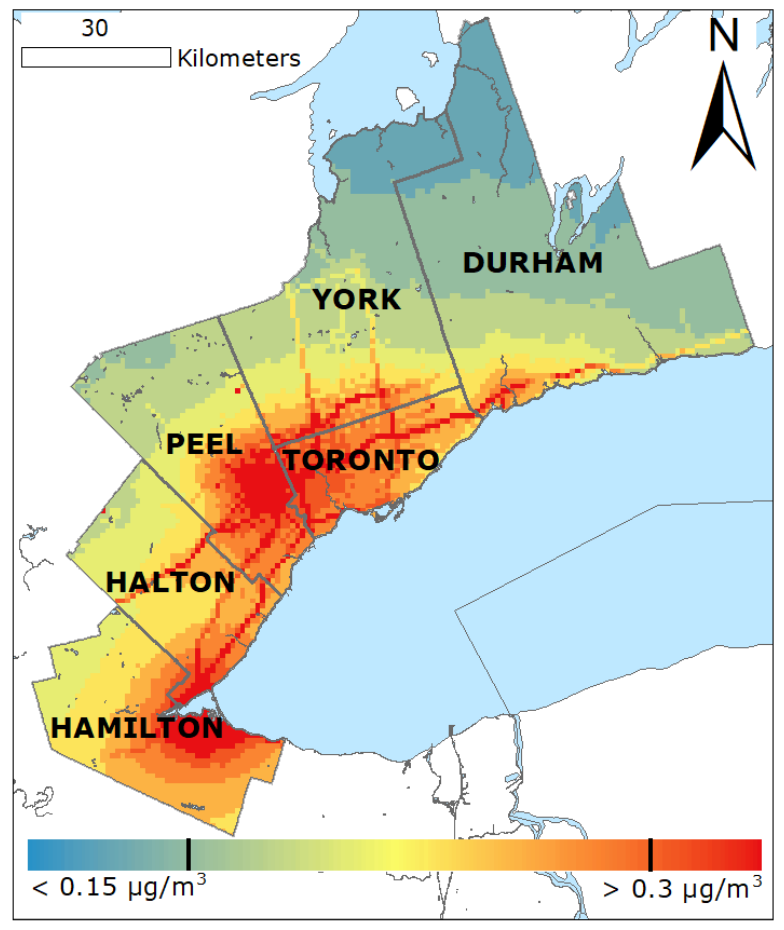

(d) $\mathrm{BC}$

Figure S8 Base case concentrations of $\mathrm{NO}_{2}, \mathrm{O}_{3}, \mathrm{PM}_{2.5}$ and $\mathrm{BC}$ in the GTHA 
Figure $\mathrm{S} 9$ shows the distribution of $\mathrm{NO}_{2}, \mathrm{O}_{3}, \mathrm{PM}_{2.5}$ and $\mathrm{BC}$ population exposures under the base case for each region of the GTHA. On these graphs, the regions are presented from the west to the east. We observe for $\mathrm{NO}_{2}, \mathrm{PM}_{2.5}$ and $\mathrm{BC}$ a general tendency of decrease in exposure in that direction: this highlights the influence of the pollution coming from the west of the region. The tendency is inverted for $\mathrm{O}_{3}$.

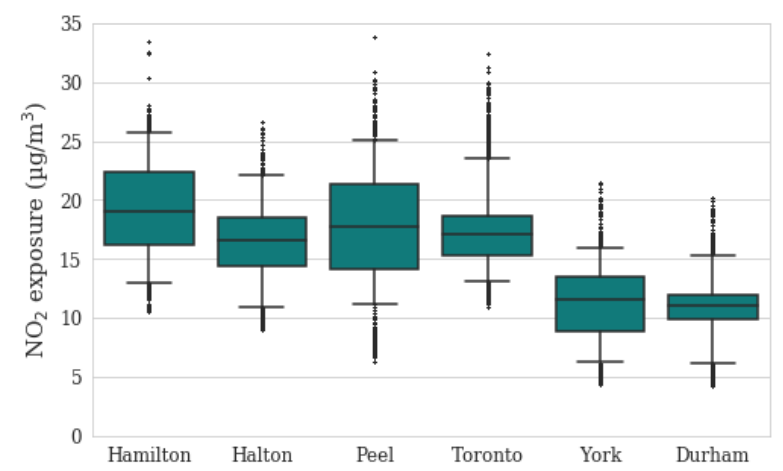

(a) $\mathrm{NO}_{2}$

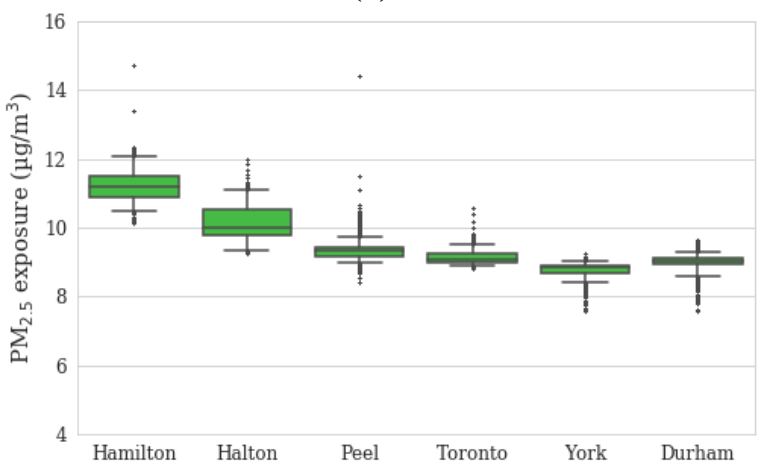

(c) $\mathbf{P M}_{2.5}$

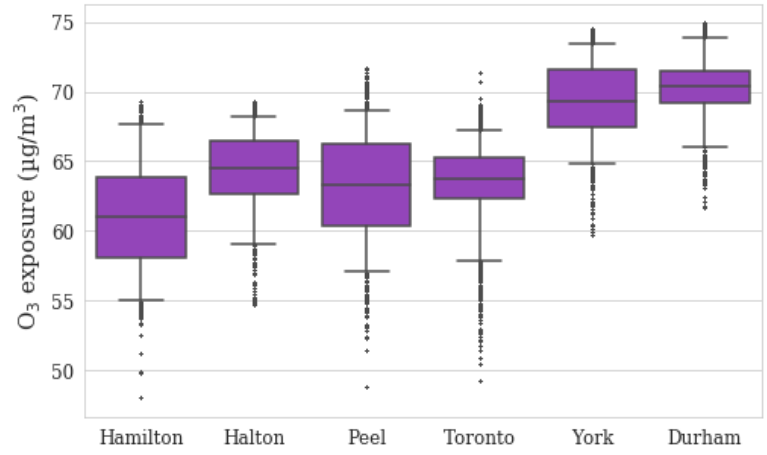

(b) $\mathbf{O}_{3}$

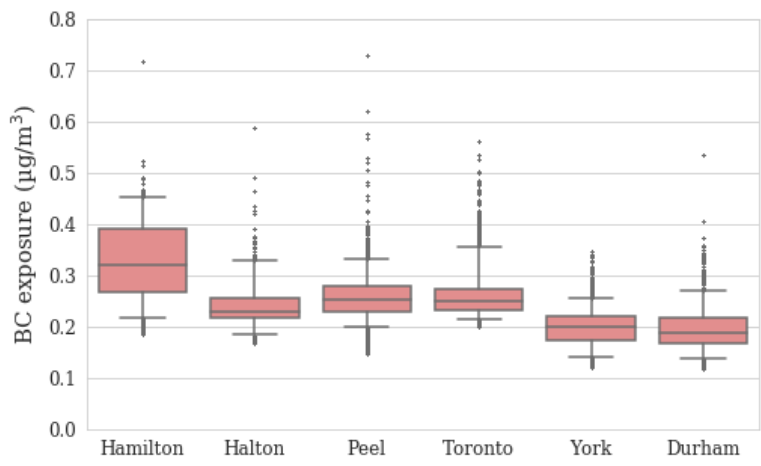

(d) $\mathrm{BC}$

Figure S9 Distribution of the population $\mathrm{NO}_{2}, \mathrm{O}_{3}, \mathrm{PM}_{2.5}$ and $\mathrm{BC}$ exposure under the base case by region of the GTHA. The lower and the upper whiskers correspond to $5^{\text {th }}$ and the $95^{\text {th }}$ percentile, respectively; the box is drawn between the first and the third quartile, and the middle line corresponds to the median exposure

In the following section, we focus on $\mathrm{NO}_{2}$ and $\mathrm{BC}$ as their emissions and ambient concentrations are the most affected by changes in traffic emissions.

\subsection{Changes in ambient concentrations under the different study cases and scenarios} Figures $\mathrm{S} 10$ and $\mathrm{S} 11$ present maps of differences in $\mathrm{NO}_{2}$ and $\mathrm{BC}$ concentrations under each study case compared to the base case. Changes in BC concentrations are substantial solely under SC3, which highlights the impact of commercial vehicles on BC concentrations. 


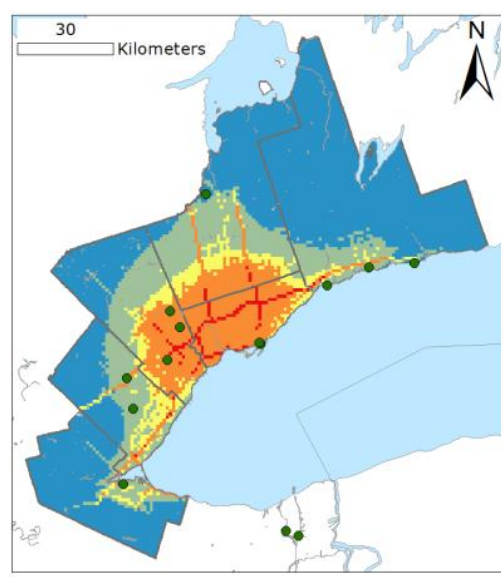

(a) SC1 - No private passenger vehicles

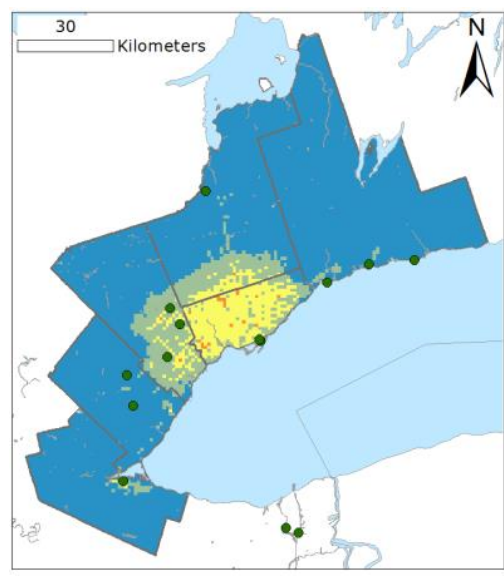

(b) SC2 - No transit buses

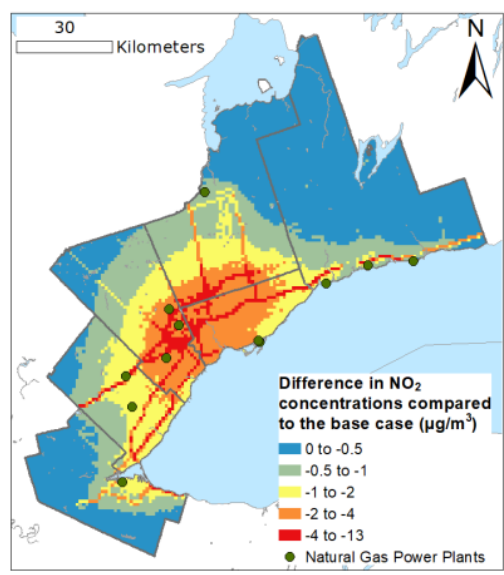

(c) SC3 - No commercial vehicles

Figure S10 Maps of differences in $\mathrm{NO}_{2}$ concentrations between the base case and the three study cases

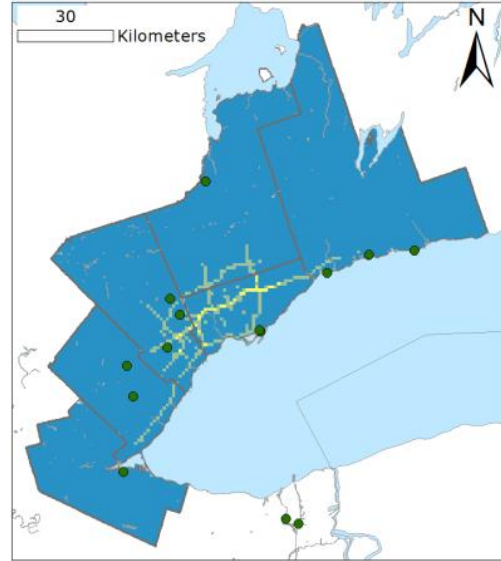

(a) SC1 - No private passenger vehicles

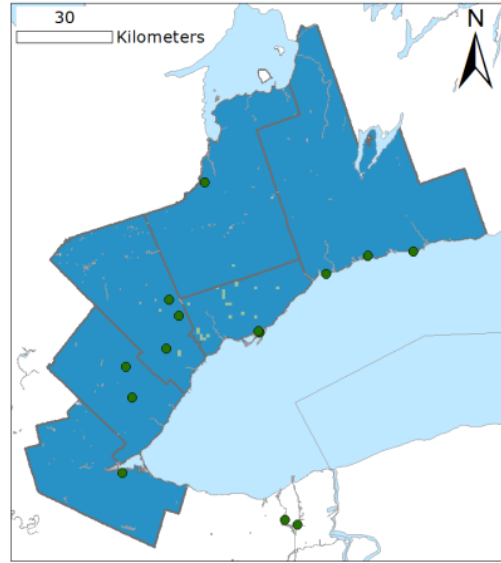

(b) SC2 - No transit buses

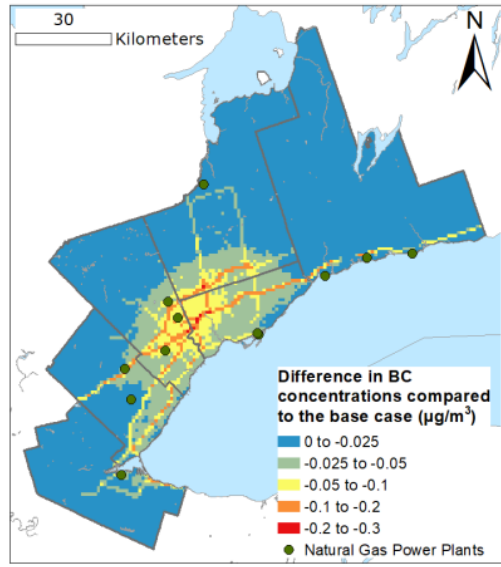

(c) SC3 - No commercial vehicles

Figure S11 Maps of differences in BC concentrations between the base case and the study cases

Figures $\mathrm{S} 12$ and $\mathrm{S} 13$ display differences in $\mathrm{NO}_{2}$ and $\mathrm{BC}$ concentrations under each scenario compared to the base case. Only S3 brings noticeable decreases in BC concentrations. It seems that $\mathrm{S} 1 \mathrm{~b}$ and $\mathrm{S} 2$ have a similar impact on $\mathrm{NO}_{2}$ concentrations, as is the case for $\mathrm{S} 1$ and $\mathrm{S} 3$. Under the scenarios of electrification, we do not observe substantial changes in $\mathrm{NO}_{2}$ ad $\mathrm{BC}$ concentrations around the natural gas power plants. 


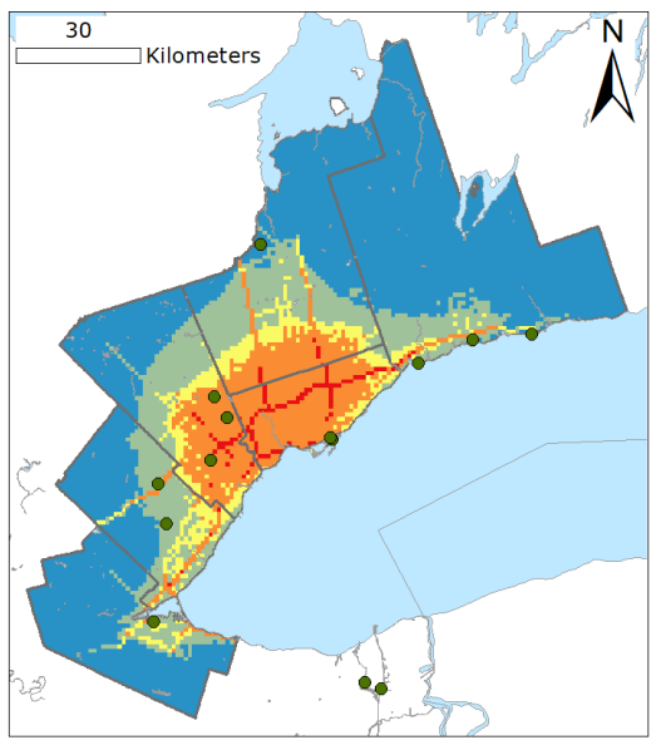

(a) $\mathrm{S} 1(100 \% \mathrm{EV})$

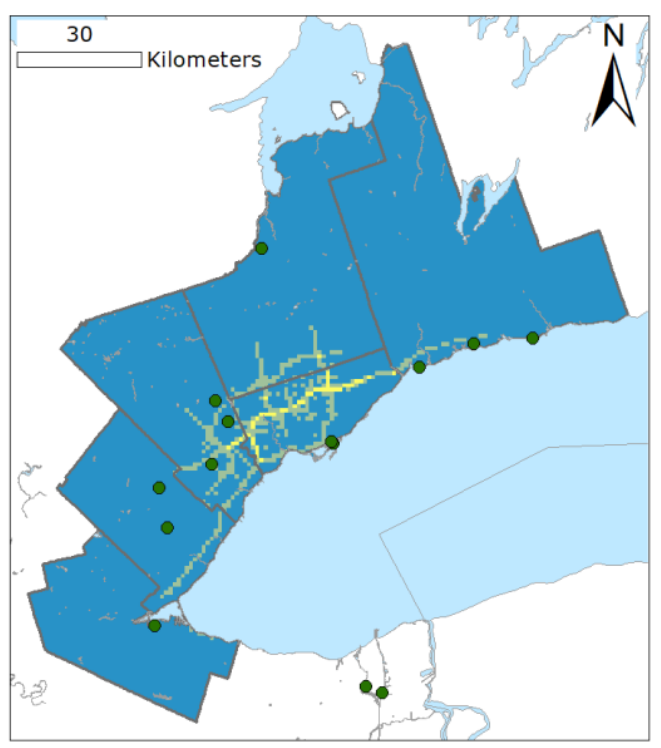

(b) S1a $(20 \% \mathrm{EV})$

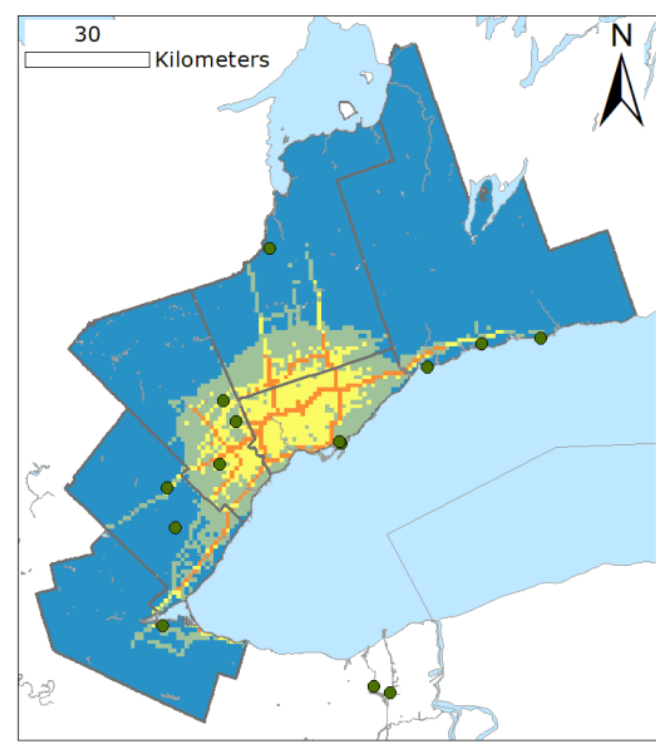

(c) $\mathrm{S} 1 \mathrm{~b}(50 \% \mathrm{EV})$

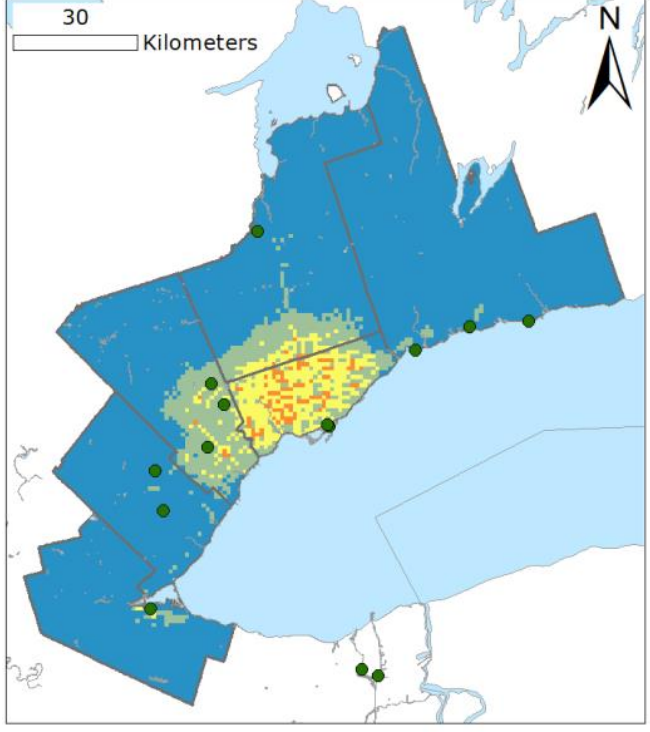

(d) $\mathrm{S2}(100 \% \mathrm{~EB})$

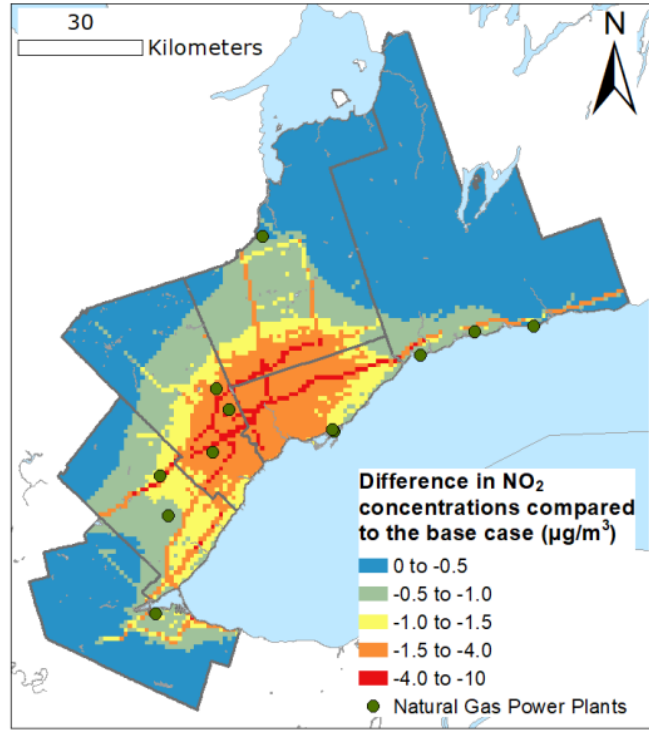

(e) S3 (Cleaner Trucks)

Figure S12 Maps of differences in $\mathrm{NO}_{2}$ concentrations between the base case and the scenarios 


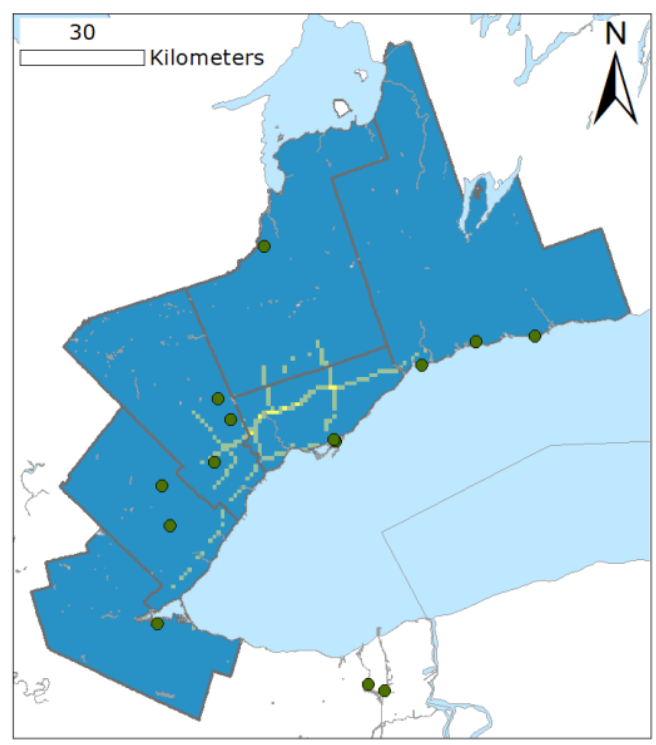

(a) $\mathrm{S} 1(100 \% \mathrm{EV})$

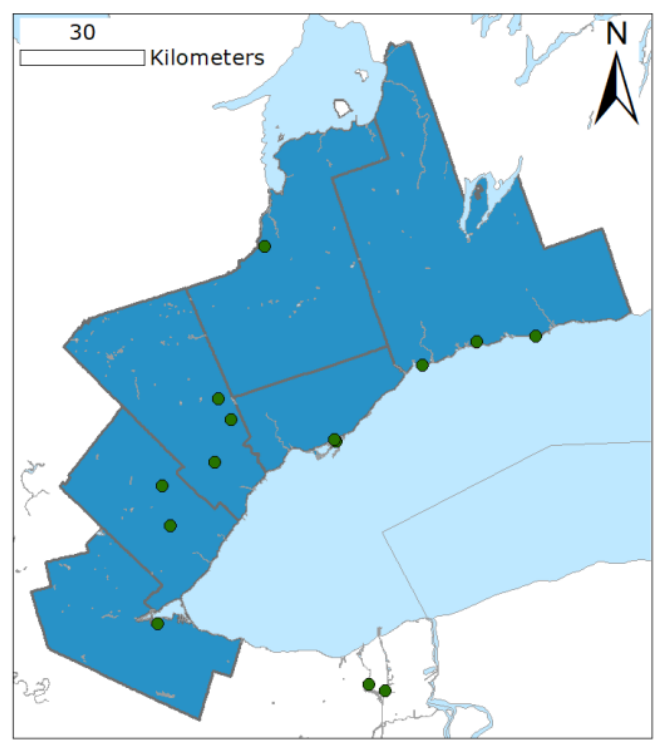

(b) S1a $(20 \% \mathrm{EV})$

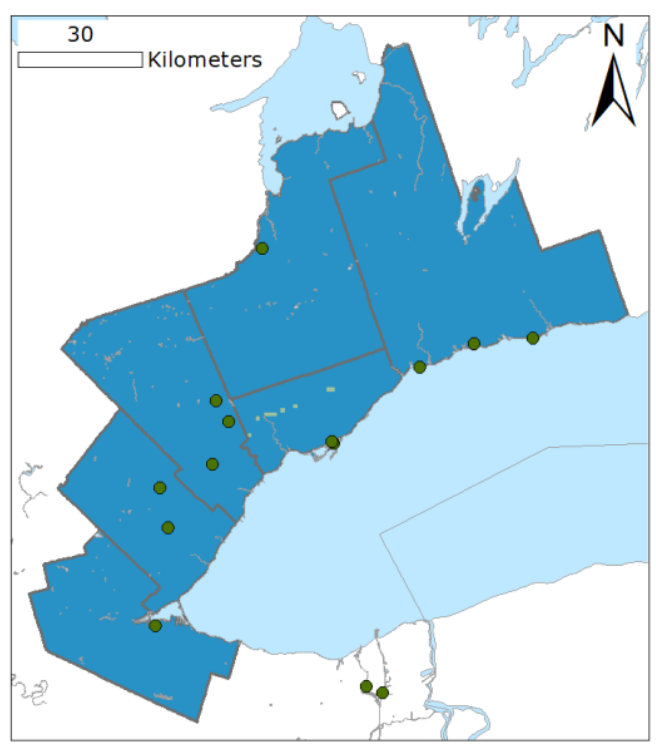

(c) $\mathrm{S1b}(50 \% \mathrm{EV})$

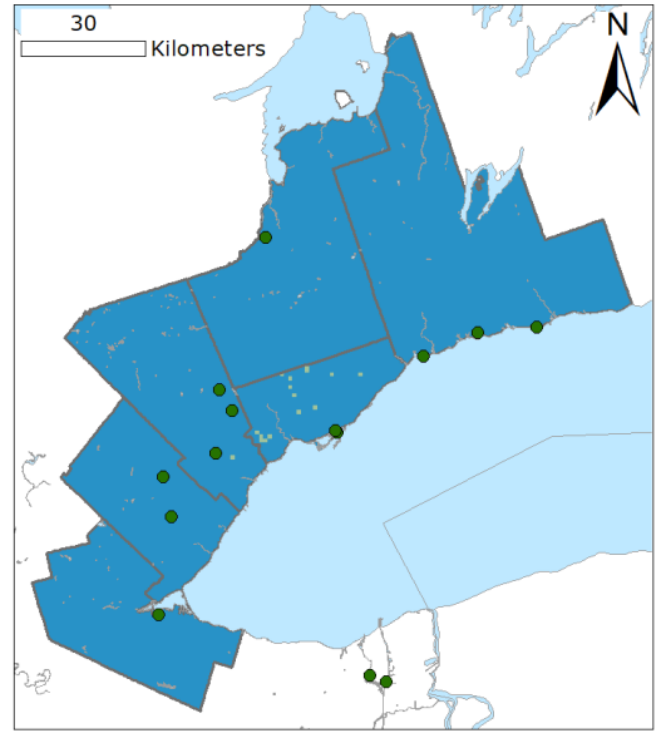

(d) S2 (100\% BEB)

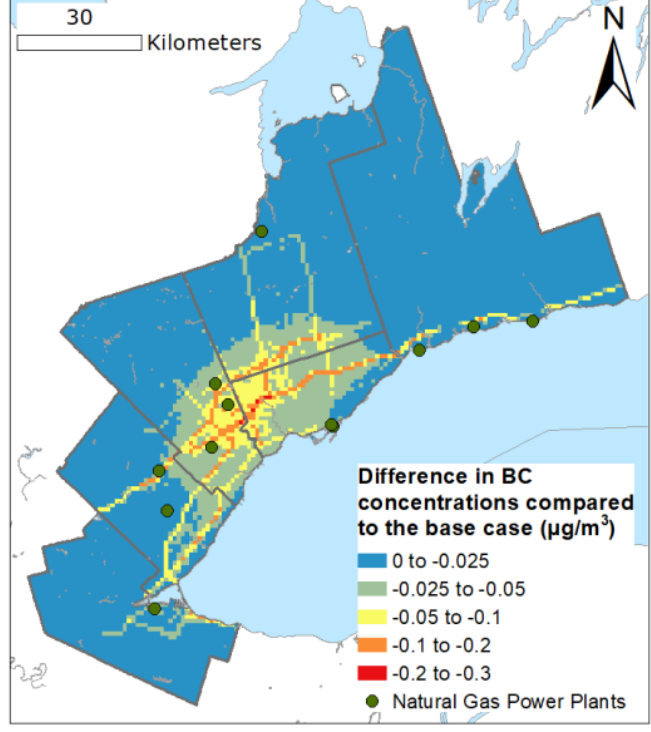

(e) S3 (Cleaner Trucks)

Figure S13 Maps of differences in BC concentrations between the base case and the scenarios 


\subsection{Changes in population exposure under the study cases and scenarios}

Figure S14 displays the distribution of the percent change (calculated as in equation 1) in population exposure to $\mathrm{NO}_{2}$ and $\mathrm{BC}$ under the three study cases, compared to the base case. Changes in exposure under SC3 suggest that commercial vehicles are the major contributors to high $\mathrm{NO}_{2}$ and $\mathrm{BC}$ exposure, followed closely by private passenger vehicles. Transit buses affect the exposures by less than $10 \%$ on average.

Percent change $(\%)=\frac{E_{\text {case study }}-E_{\text {base case }}}{E_{\text {base case }}} * 100$

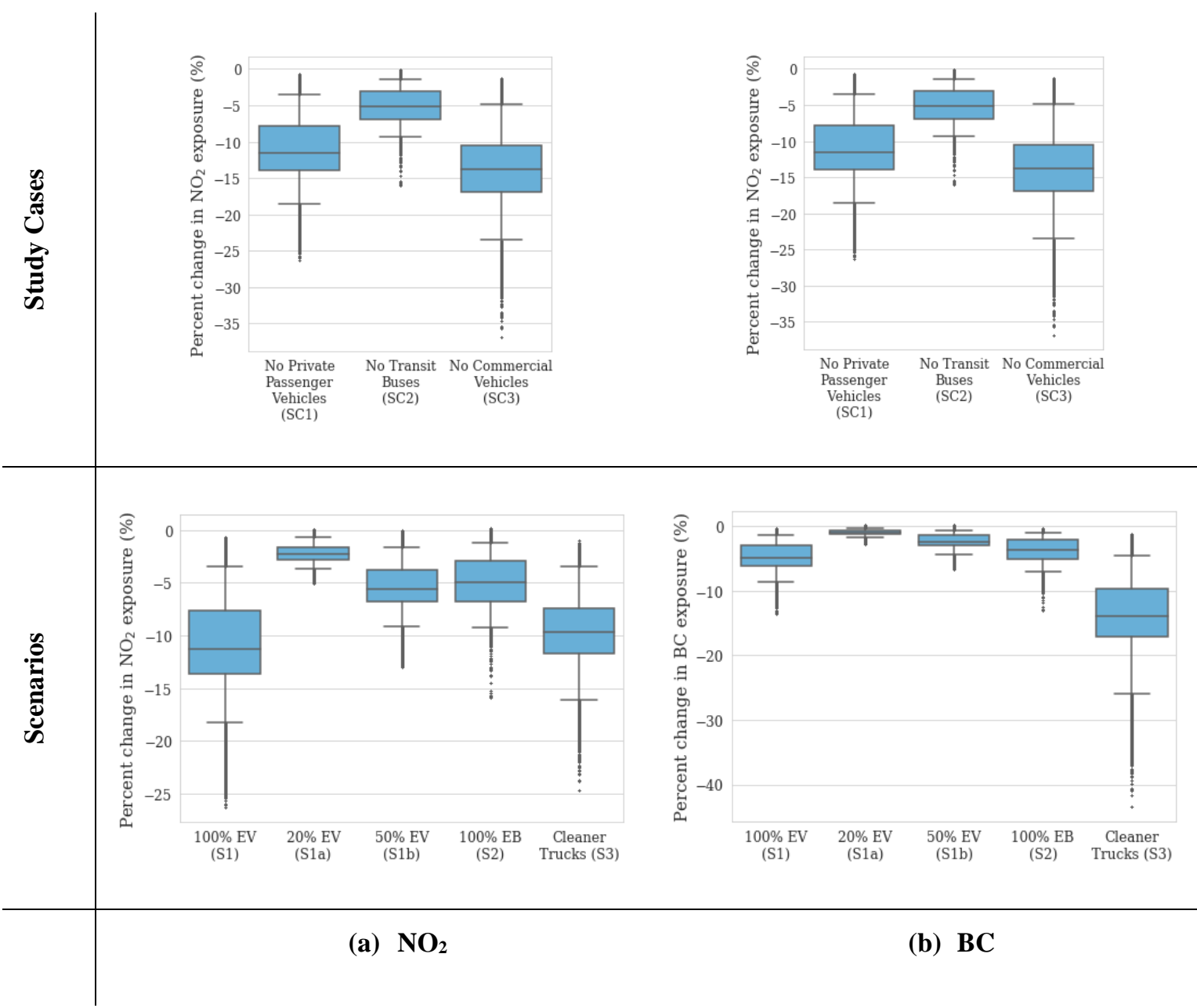

Figure S14 Distribution of the percent change in (a) $\mathrm{NO}_{2}$ and (b) $\mathrm{BC}$ residential exposure by dissemination area under the study cases and under the scenarios compared to the base case. The lower and the upper whiskers correspond to $5^{\text {th }}$ and the $95^{\text {th }}$ percentile, respectively; the box is drawn between the first and the third quartile, and the middle line corresponds to the median exposure 
Figure S15 and S16 display the distribution by region of the percent change in $\mathrm{NO}_{2}$ and $\mathrm{BC}$ population exposure under the study cases and scenarios compared to the base case. Changes in $\mathrm{NO}_{2}$ exposures are somewhat close in most regions and under the study cases $\mathrm{SC} 1$ and $\mathrm{SC} 3$, but this is not the case for BC, which shows larger changes under SC3. Under S1 (100\% EV), we observe considerable decreases in $\mathrm{NO}_{2}$ exposure, and also important decreases in $\mathrm{BC}$ exposure, although not as substantial. Decreases in BC are the largest under S3 (Cleaner Trucks).

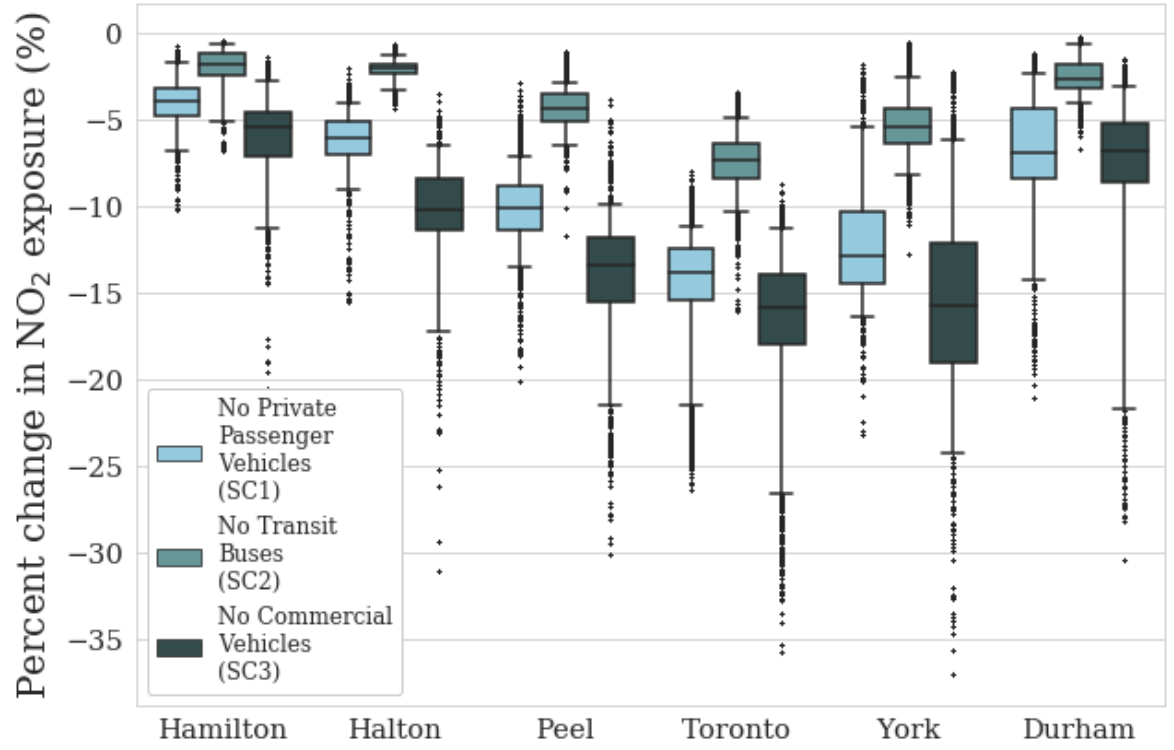

(a) $\mathrm{NO}_{2}$

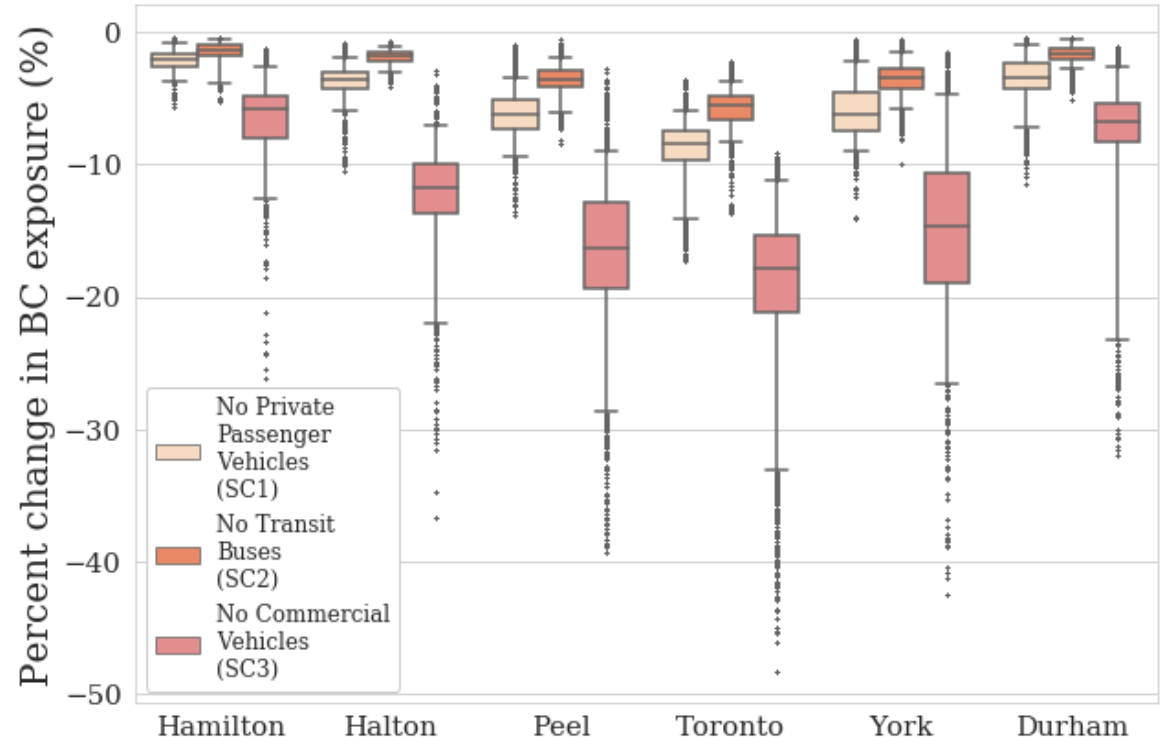

(b) $\mathbf{B C}$

Figure S15 Distribution by region of the percent change in $\mathrm{NO}_{2}$ and $\mathrm{BC}$ population exposure under the study cases compared to the base case. The lower and the upper whiskers correspond to $5^{\text {th }}$ and the $95^{\text {th }}$ percentile, respectively; the box is drawn between the first and the third quartile, and the middle line corresponds to the median exposure 


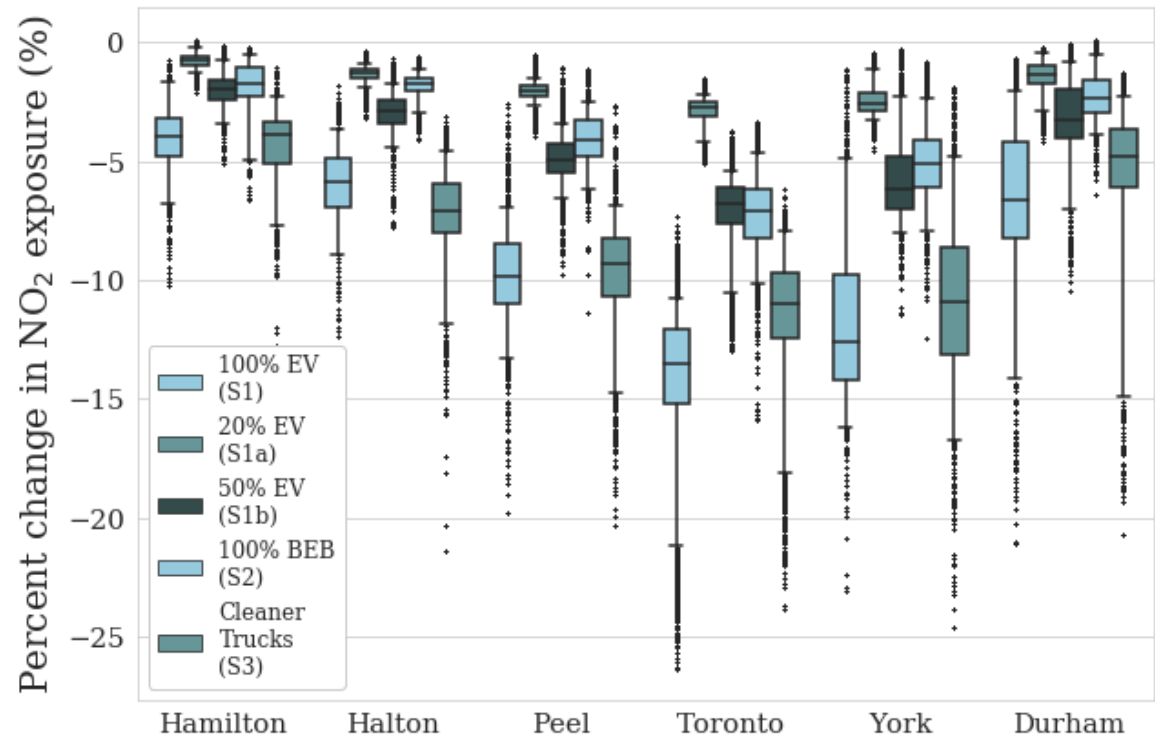

(a) $\mathrm{NO}_{2}$

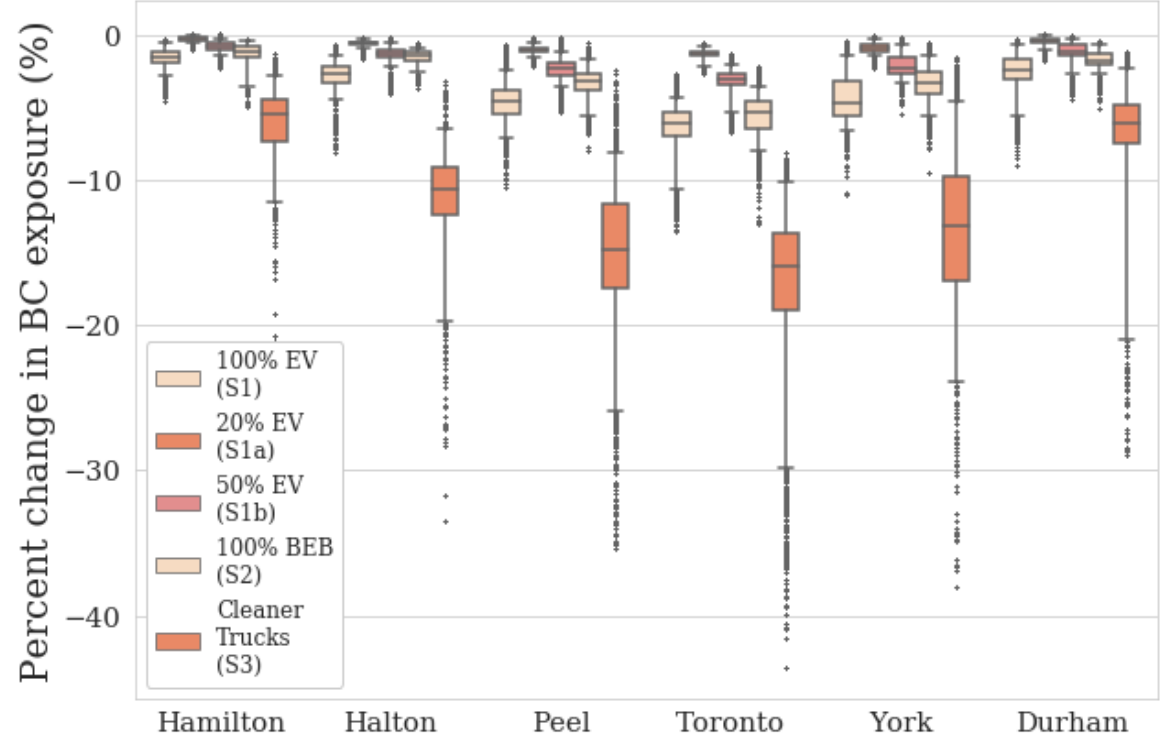

(b) BC

Figure S16 Distribution by region of the percent change in $\mathrm{NO}_{2}$ and $\mathrm{BC}$ population exposure under the scenarios compared to the base case. The lower and the upper whiskers correspond to $5^{\text {th }}$ and the $95^{\text {th }}$ percentile, respectively; the box is drawn between the first and the third quartile, and the middle line corresponds to the median exposure 


\subsection{Assessment of the health outcomes}

\subsubsection{Description of the results}

Table S18 describes the results of the assessment of the health outcomes based on population exposure estimated using concentrations averaged over the four weeks simulated. Attributable numbers of YLL and premature deaths associated with $\mathrm{NO}_{2}$ are in absolute the largest, so the YLL and premature deaths are associated with changes in $\mathrm{NO}_{2}$ exposure.

Table S18 Comparison of the annual attributable Years of Life Lost (YLL) and attributable number of premature deaths associated with each vehicle category and prevented under each scenario.

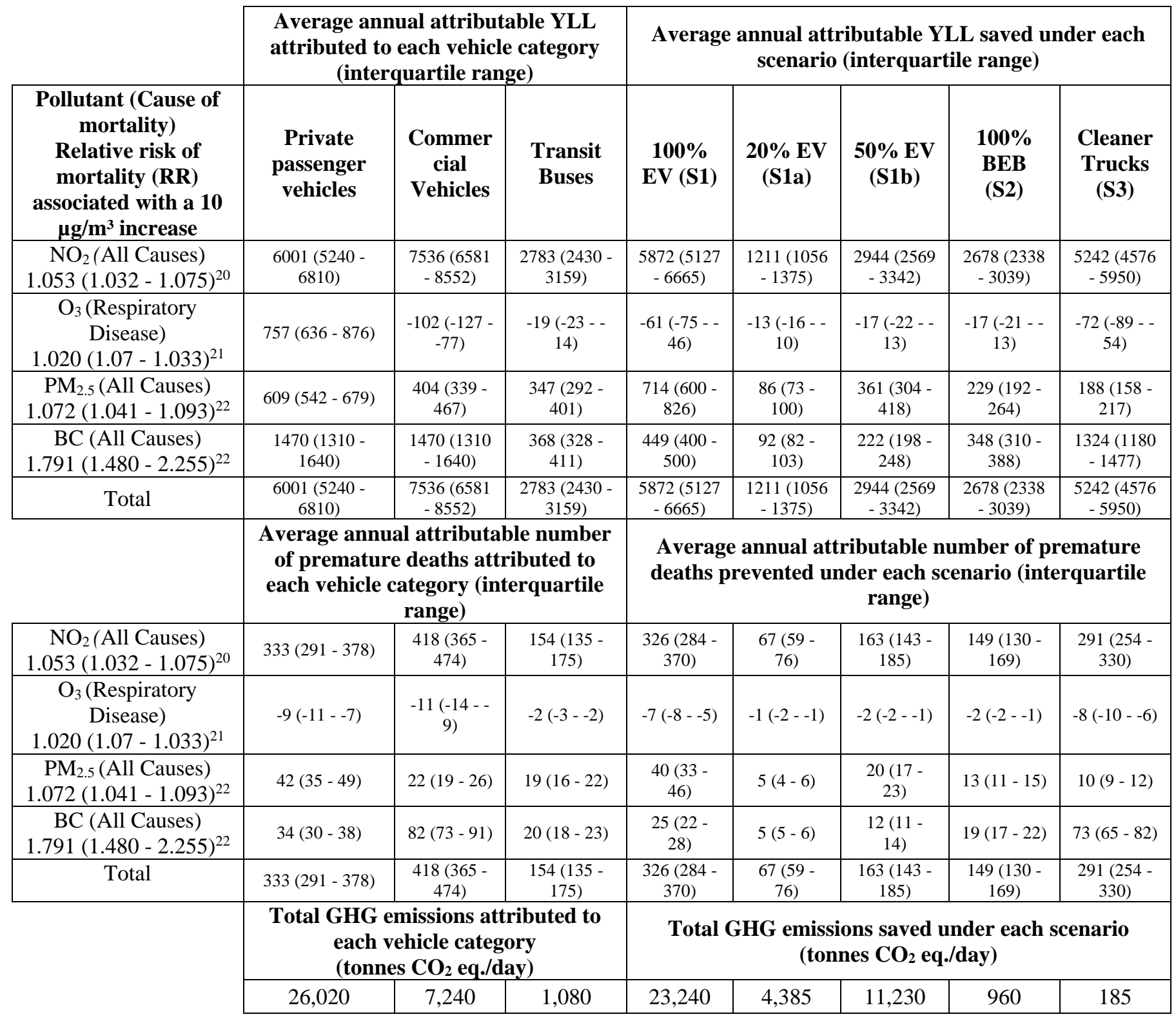




\subsubsection{Uncertainty analysis}

Based on the uncertainty analysis conducted on the pollutant risk ratios, Figures S17 and S18 display the distribution of years of life lost (YLL) and premature deaths attributed to each vehicle category, as well as the distribution of years of life saved and premature deaths prevented under each scenario.

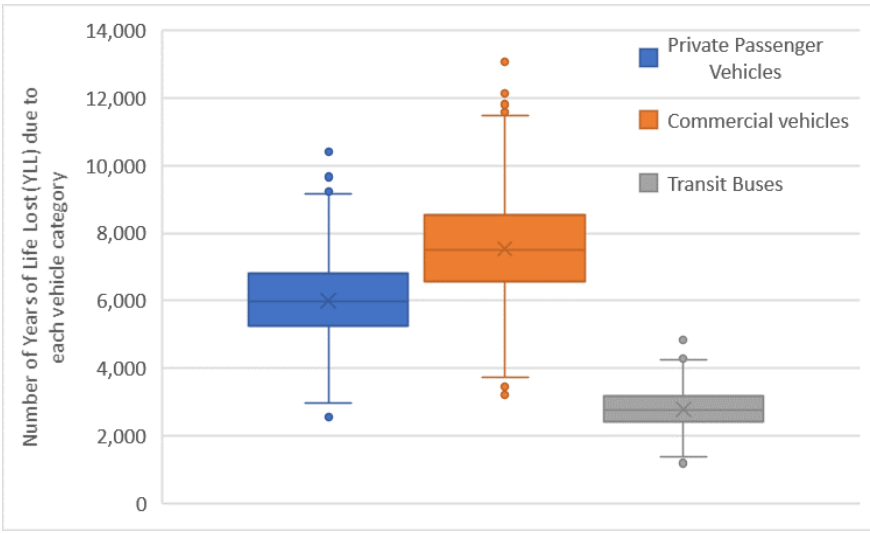

(a) Years of Life

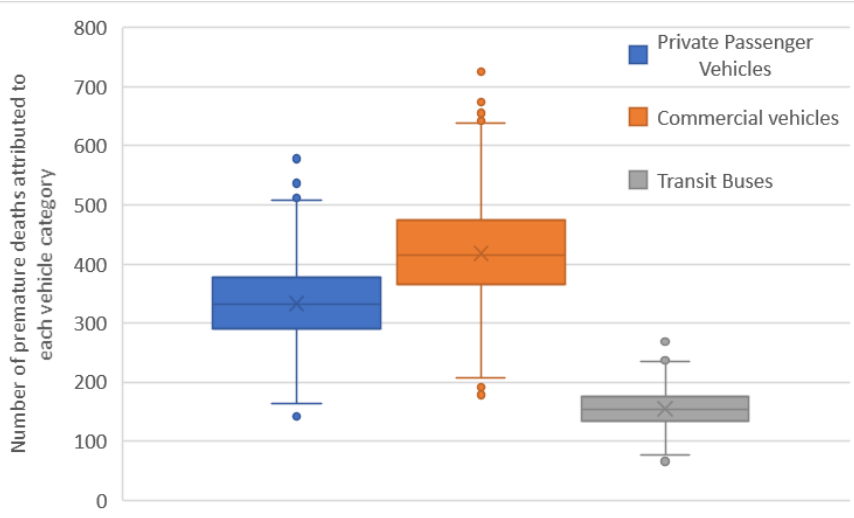

(b) Premature deaths

Figure S17 Distribution of the numbers of Years of Life Lost (YLL) and premature deaths attributed to each vehicle category

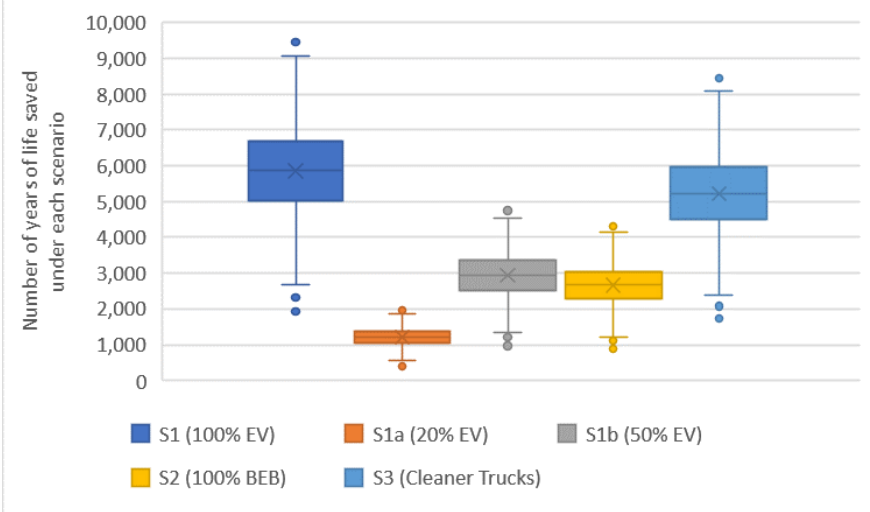

(a) Years of Life

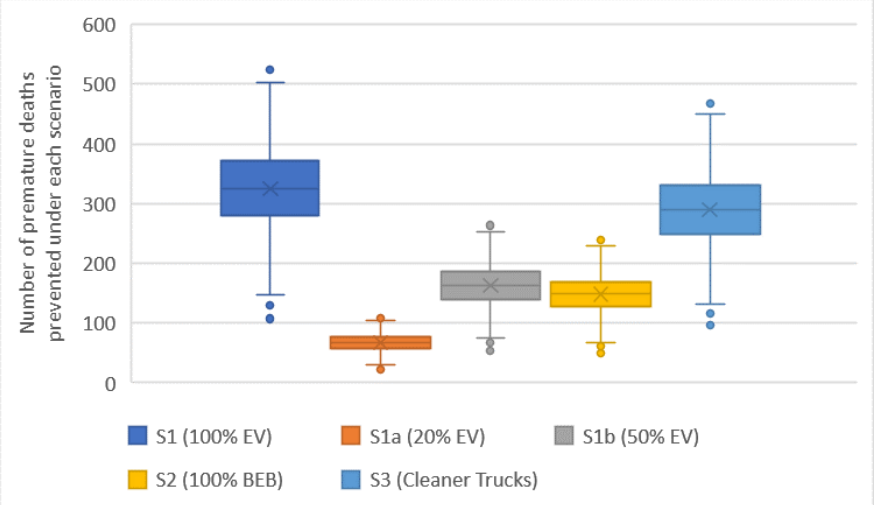

(b) Premature deaths

Figure S18 Distribution of the numbers of years of life saved and premature deaths prevented under each scenario

\subsubsection{Comparison of the four weeks simulated}

Using concentrations simulated for the weeks of March $20^{\text {th }}$, May $8^{\text {th }}$, August $14^{\text {th }}$, and November $27^{\text {th }}, 2016$, separately, as well as averaged over the four weeks, we determined the annual YLL and number of premature deaths attributed to each vehicle category and saved under each scenario based on the concentrations simulated for each week separately and averaged (Tables S19 and S20). 
We obtain very similar values for the four weeks simulated. When analyzing the results obtained from the averaged concentrations or from the concentrations of each week separately, the comparisons of the scenarios and study cases show the same trends. Therefore, it seems appropriate to us to only use concentrations averaged over the four weeks to conduct comparisons between the different scenarios; however, the concentrations obtained by averaging the four weeks concentrations should not be considered as the absolute truth.

Table S19 Comparison of the annual Years of Life Lost (YLL) attributed to each vehicle category and saved under each scenario based on the concentrations simulated for each week separately (March $20^{\text {th }}$, May $8^{\text {th }}$, August $14^{\text {th }}$, and November $27^{\text {th }}, 2016$ ) and averaged

\begin{tabular}{|c|c|c|c|c|c|c|c|c|}
\hline & \multicolumn{3}{|c|}{$\begin{array}{c}\text { YLL attributed to each vehicle } \\
\text { category }\end{array}$} & \multicolumn{5}{|c|}{ YLL saved under each scenario } \\
\hline & $\begin{array}{c}\text { Private } \\
\text { Household } \\
\text { Vehicles }\end{array}$ & $\begin{array}{l}\text { Commercial } \\
\text { Vehicles }\end{array}$ & $\begin{array}{c}\text { Transit } \\
\text { Buses }\end{array}$ & $\begin{array}{c}100 \% \\
\text { EV } \\
\text { (S1) }\end{array}$ & $\begin{array}{l}20 \% \text { EV } \\
\text { (S1a) }\end{array}$ & $\begin{array}{c}50 \% \\
\text { EV } \\
\text { (S1b) }\end{array}$ & $\begin{array}{l}100 \% \\
\text { BEB } \\
\text { (S2) }\end{array}$ & $\begin{array}{c}\text { Cleaner } \\
\text { Trucks }(\mathbf{S 3})\end{array}$ \\
\hline Average & 5,985 & 7,515 & 2,785 & 5,855 & 1,205 & 2,935 & 2,670 & 5,225 \\
\hline March & 6,220 & 7,505 & 2,735 & 6,055 & 1,275 & 3,055 & 2,735 & 5,050 \\
\hline May & 6,105 & 7,765 & 2,695 & 5,935 & 1,180 & 2,960 & 2,680 & 5,570 \\
\hline August & 5,510 & 7,345 & 2,430 & 5,360 & 1,210 & 2,685 & 2,420 & 4,980 \\
\hline November & 6,070 & 7,400 & 3,225 & 6,045 & 1,155 & 3,030 & 2,802 & 5,280 \\
\hline
\end{tabular}

Table S20 Comparison of the annual premature deaths attributed to each vehicle category and prevented under each scenario based on the concentrations simulated for each week separately (March $\mathbf{2 0}^{\text {th }}$, May $8^{\text {th }}$, August $14^{\text {th }}$, and November $27^{\text {th }}, 2016$ ) and averaged

\begin{tabular}{|c|c|c|c|c|c|c|c|c|}
\hline & \multicolumn{3}{|c|}{$\begin{array}{c}\text { Premature deaths attributed to each } \\
\text { vehicle category }\end{array}$} & \multicolumn{5}{|c|}{ Premature deaths prevented under each scenario } \\
\hline & $\begin{array}{c}\text { Private } \\
\text { Household } \\
\text { Vehicles }\end{array}$ & $\begin{array}{l}\text { Commercial } \\
\text { Vehicles }\end{array}$ & $\begin{array}{c}\text { Transit } \\
\text { Buses }\end{array}$ & $\begin{array}{c}100 \% \\
\text { EV } \\
\text { (S1) }\end{array}$ & $\begin{array}{l}20 \% \text { EV } \\
\text { (S1a) }\end{array}$ & $\begin{array}{c}50 \% \\
\text { EV } \\
\text { (S1b) }\end{array}$ & $\begin{array}{c}100 \% \\
\text { BEB } \\
\text { (S2) }\end{array}$ & $\begin{array}{c}\text { Cleaner } \\
\text { Trucks (S3) }\end{array}$ \\
\hline Average & 330 & 415 & 155 & 325 & 65 & 165 & 145 & 290 \\
\hline March & 345 & 415 & 150 & 335 & 70 & 170 & 150 & 280 \\
\hline May & 335 & 430 & 150 & 330 & 65 & 165 & 150 & 310 \\
\hline August & 310 & 415 & 135 & 300 & 70 & 150 & 135 & 280 \\
\hline November & 335 & 410 & 180 & 335 & 65 & 170 & 155 & 295 \\
\hline
\end{tabular}




\subsection{Results obtained with the Air Quality Benefits Assessment Tool (AQBAT) of Health Canada}

We also used the CRFs of the Air Quality Benefits Assessment Tool (AQBAT) of Health Canada $^{23}$ to determine the number of premature deaths attributed to each vehicle category or saved under each scenario. Table S21 presents a comparison of the results. A negative attributable number of premature deaths (APD) represents a number of premature deaths prevented; a positive APD represents a number of premature deaths induced.

Similarly to our methodology, AQBAT quantifies for $\mathrm{PM}_{2.5}$ the chronic exposure mortality; the results are therefore of similar order of magnitude. However, the attributable number of premature deaths for $\mathrm{NO}_{2}$ based on AQBAT is lower than based on our methodology, because AQBAT only accounts for acute exposure mortality; nevertheless, the ranking of study cases and scenarios is the same using both methodologies.

Table S21 Comparison of the annual number of premature deaths attributed to each vehicle category and prevented under each scenario and determined with AQBAT and according to the methodology presented in this paper

\begin{tabular}{|c|c|c|c|c|c|c|c|c|c|}
\hline & \multirow[b]{2}{*}{$\begin{array}{l}\text { Pollutant (Cause of } \\
\text { mortality) }\end{array}$} & \multicolumn{3}{|c|}{$\begin{array}{l}\text { Attributable number of premature } \\
\text { deaths for each vehicle category }\end{array}$} & \multicolumn{5}{|c|}{$\begin{array}{c}\text { Attributable number of premature deaths for } \\
\text { each scenario }\end{array}$} \\
\hline & & $\begin{array}{c}\text { Private } \\
\text { passenger } \\
\text { vehicles }\end{array}$ & $\begin{array}{l}\text { Commercial } \\
\text { Vehicles }\end{array}$ & $\begin{array}{l}\text { Transit } \\
\text { Buses }\end{array}$ & $\begin{array}{c}100 \% \\
\text { EV } \\
\text { (S1) }\end{array}$ & $\begin{array}{l}20 \% \\
\text { EV } \\
\text { (S1a) }\end{array}$ & $\begin{array}{l}50 \% \\
\text { EV } \\
\text { (S1b) }\end{array}$ & $\begin{array}{c}100 \% \\
\text { EB } \\
\text { (S2) }\end{array}$ & $\begin{array}{c}\text { New Truck } \\
\text { Technologies } \\
\text { (S3) }\end{array}$ \\
\hline \multirow{3}{*}{ 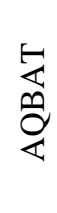 } & $\mathrm{NO}_{2}$ (Acute exposure) & -23 & -30 & -10 & -22 & -5 & -11 & -10 & -20 \\
\hline & $\mathrm{O}_{3}$ (Acute exposure) & 0 & 0 & 0 & 0 & 0 & 0 & 0 & 0 \\
\hline & $\mathrm{PM}_{2.5}$ (Chronic exposure) & -61 & -33 & -21 & -47 & -4 & -17 & -17 & -6 \\
\hline \multirow{3}{*}{ 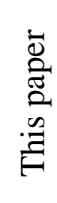 } & $\mathrm{NO}_{2}($ Chronic exposure $)$ & -333 & -418 & -154 & -326 & -67 & -163 & -149 & -291 \\
\hline & $\mathrm{O}_{3}($ Chronic exposure $)$ & 9 & 11 & 2 & 7 & 1 & 2 & 2 & 8 \\
\hline & $\mathrm{PM}_{2.5}$ (Chronic exposure) & -42 & -22 & -19 & -40 & -5 & -20 & -13 & -10 \\
\hline
\end{tabular}

\subsection{Graphs by population characteristics}

Figure $\mathrm{S} 19$ shows the distribution in $\mathrm{NO}_{2}$ exposure of the population of the GTHA by age and by sex. We observe little differences between the age bins. There is also no apparent difference between males and females. 


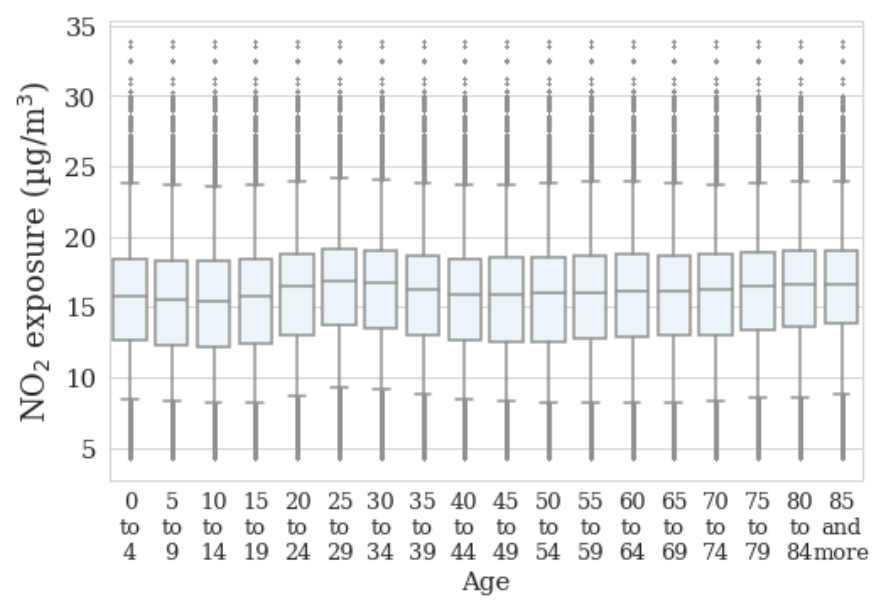

(a) Age

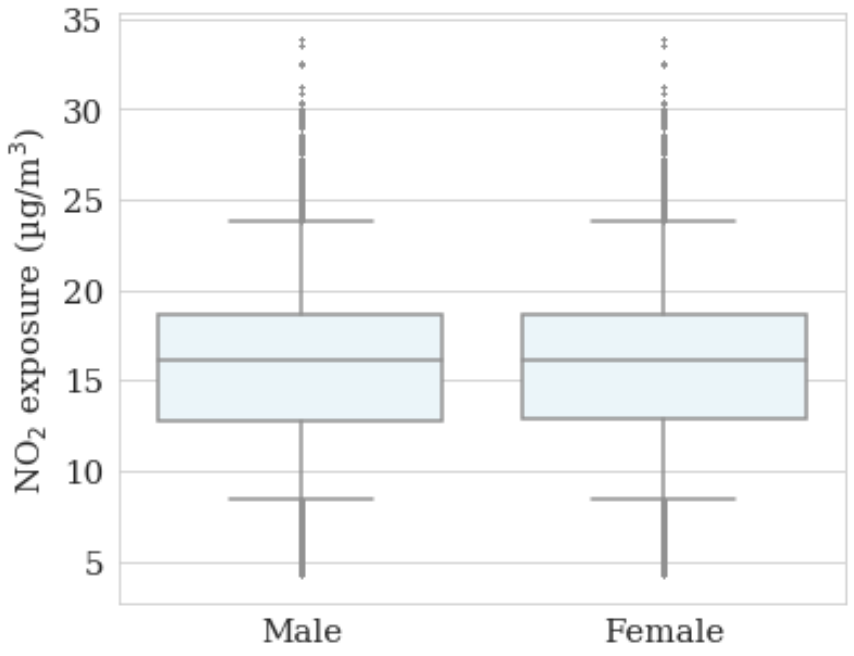

(b) Sex

Figure S19 Distribution of the population $\mathrm{NO}_{2}$ exposure under the base case by age and sex. The lower and the upper whiskers correspond to $5^{\text {th }}$ and the $95^{\text {th }}$ percentile, respectively; the box is drawn between the first and the third quartile, and the middle line corresponds to the median exposure

\section{REFERENCES}

(1) Bartholome, E.; Belward, A. S. GLC2000: A New Approach to Global Land Cover Mapping from Earth Observation Data. Int. J. Remote Sens. 2005, 26 (9), 1959-1977.

(2) Environment and Climate Change Canada. Historical Data - Climate http://climate.weather.gc.ca/historical_data/search_historic_data_e.html (accessed May 1, 2019).

(3) Smyth, S. C.; Jiang, W.; Roth, H.; Moran, M. D.; Makar, P. A.; Yang, F.; Bouchet, V. S.; Landry, H. A Comparative Performance Evaluation of the AURAMS and CMAQ AirQuality Modelling Systems. Atmos. Environ. 2009, 43 (5), 1059-1070. https://doi.org/10.1016/j.atmosenv.2008.11.027.

(4) Simons, A. Road Transport: New Life Cycle Inventories for Fossil-Fuelled Passenger Cars and Non-Exhaust Emissions in Ecoinvent V3. Int. J. Life Cycle Assess. 2016, 21 (9), 1299-1313. https://doi.org/10.1007/s11367-013-0642-9.

(5) Environment and Climate Change Canada. National Pollutant Release Inventory http://www.ec.gc.ca/inrp-npri/ (accessed Aug 9, 2017).

(6) U.S. EPA. Air Markets Program Data | Clean Air Markets.

(7) Environment and Climate Change Canada. Greenhouse Gas Reporting Program (GHGRP) - Facility Greenhouse Gas (GHG) Data.

(8) Intergovernmental Panel on Climate Change (IPCC). Climate Change 2014: Synthesis Report. Contribution of Working Groups I, II and III to the Fifth Assessment Report of the 
Intergovernmental Panel on Climate Change; Geneva, Switzerland, 2014.

(9) Independent Electricity System Operator. Generator Output and Capacity http://www.ieso.ca/power-data/data-directory (accessed Jul 23, 2018).

(10) Mallia, E.; Lewis, G. Life Cycle Greenhouse Gas Emissions of Electricity Generation in the Province of Ontario, Canada. Int. J. Life Cycle Assess. 2013, 18 (2), 377-391. https://doi.org/10.1007/s11367-012-0501-0.

(11) Littlefield, J. A.; Marriott, J.; Schivley, G. A.; Skone, T. J. Synthesis of Recent GroundLevel Methane Emission Measurements from the U.S. Natural Gas Supply Chain. J. Clean. Prod. 2017, 148, 118-126. https://doi.org/10.1016/J.JCLEPRO.2017.01.101.

(12) Independent Electricity System Operator. 2016 Year-End Data http://www.ieso.ca/en/Corporate-IESO/Media/Year-End-Data/2016 (accessed Feb 3, 2020).

(13) Zhou, B.; Wu, Y.; Zhou, B.; Wang, R.; Ke, W.; Zhang, S.; Hao, J. Real-World Performance of Battery Electric Buses and Their Life-Cycle Benefits with Respect to Energy Consumption and Carbon Dioxide Emissions. Energy 2016, 96, 603-613. https://doi.org/10.1016/j.energy.2015.12.041.

(14) Qin, N.; Gusrialdi, A.; Paul Brooker, R.; T-Raissi, A. Numerical Analysis of Electric Bus Fast Charging Strategies for Demand Charge Reduction. Transp. Res. Part A Policy Pract. 2016, 94, 386-396. https://doi.org/10.1016/j.tra.2016.09.014.

(15) Gao, Z.; Lin, Z.; LaClair, T. J.; Liu, C.; Li, J. M.; Birky, A. K.; Ward, J. Battery Capacity and Recharging Needs for Electric Buses in City Transit Service. Energy 2017, 122, 588600. https://doi.org/10.1016/j.energy.2017.01.101.

(16) Xylia, M.; Leduc, S.; Patrizio, P.; Kraxner, F.; Silveira, S. Locating Charging Infrastructure for Electric Buses in Stockholm. Transp. Res. Part C Emerg. Technol. 2017, 78, 183-200. https://doi.org/10.1016/j.trc.2017.03.005.

(17) Boylan, J. W.; Russell, A. G. PM and Light Extinction Model Performance Metrics, Goals, and Criteria for Three-Dimensional Air Quality Models. Atmos. Environ. 2006, 40 (26), 4946-4959. https://doi.org/10.1016/j.atmosenv.2005.09.087.

(18) U.S. EPA. Guideline for Regulatory Application of the Urban Airshed Model; US EPA Report No. EPA-450/4-91, 1991.

(19) Russell, A.; Dennis, R. NARSTO Critical Review of Photochemical Models and Modeling. Atmos. Environ. 2000, 34 (12-14), 2283-2324. https://doi.org/10.1016/S13522310(99)00468-9.

(20) Crouse, D. L.; Peters, P. A.; Villeneuve, P. J.; Proux, M.-O.; Shin, H. H.; Goldberg, M. S.; Johnson, M.; Wheeler, A. J.; Allen, R. W.; Atari, D. O.; Jerrett, M.; Brauer, M.; Brook, J. R.; Cakmak, S.; Burnett, R. T. Within- and between-City Contrasts in Nitrogen Dioxide and Mortality in 10 Canadian Cities; a Subset of the Canadian Census Health and Environment Cohort (CanCHEC). J. Expo. Sci. Environ. Epidemiol. 2015, 25, 482. 
(21) Jerrett, M.; Burnett, R. T.; Pope, C. A.; Ito, K.; Thurston, G.; Krewski, D.; Shi, Y.; Calle, E.; Thun, M. Long-Term Ozone Exposure and Mortality. N. Engl. J. Med. 2009, 360 (11), 1085-1095. https://doi.org/10.1056/nejmoa0803894.

(22) Janssen, N. A. H.; Hoek, G.; Simic-Lawson, M.; Fischer, P.; van Bree, L.; ten Brink, H.; Keuken, M.; Atkinson, R. W.; Anderson, H. R.; Brunekreef, B.; Cassee, F. R. Black Carbon as an Additional Indicator of the Adverse Health Effects of Airborne Particles Compared with PM10 and PM2.5. Environ. Health Perspect. 2011, 119 (12), 1691-1699. https://doi.org/10.1289/ehp.1003369.

(23) Government of Canada. Air Quality Benefits Assessment Tool (AQBAT) http://www.science.gc.ca/eic/site/063.nsf/eng/h_97170.html (accessed Nov 28, 2019). 